Center for the Advancement of Sustainability Innovations (CASI)

\title{
Initial Integrated Strategic Sustainability Plan for Fort Leonard Wood
}

Kevin J. Palmer, Sarah B. Nemeth, Annette L. Stumpf, and Susan J. Bevelheimer

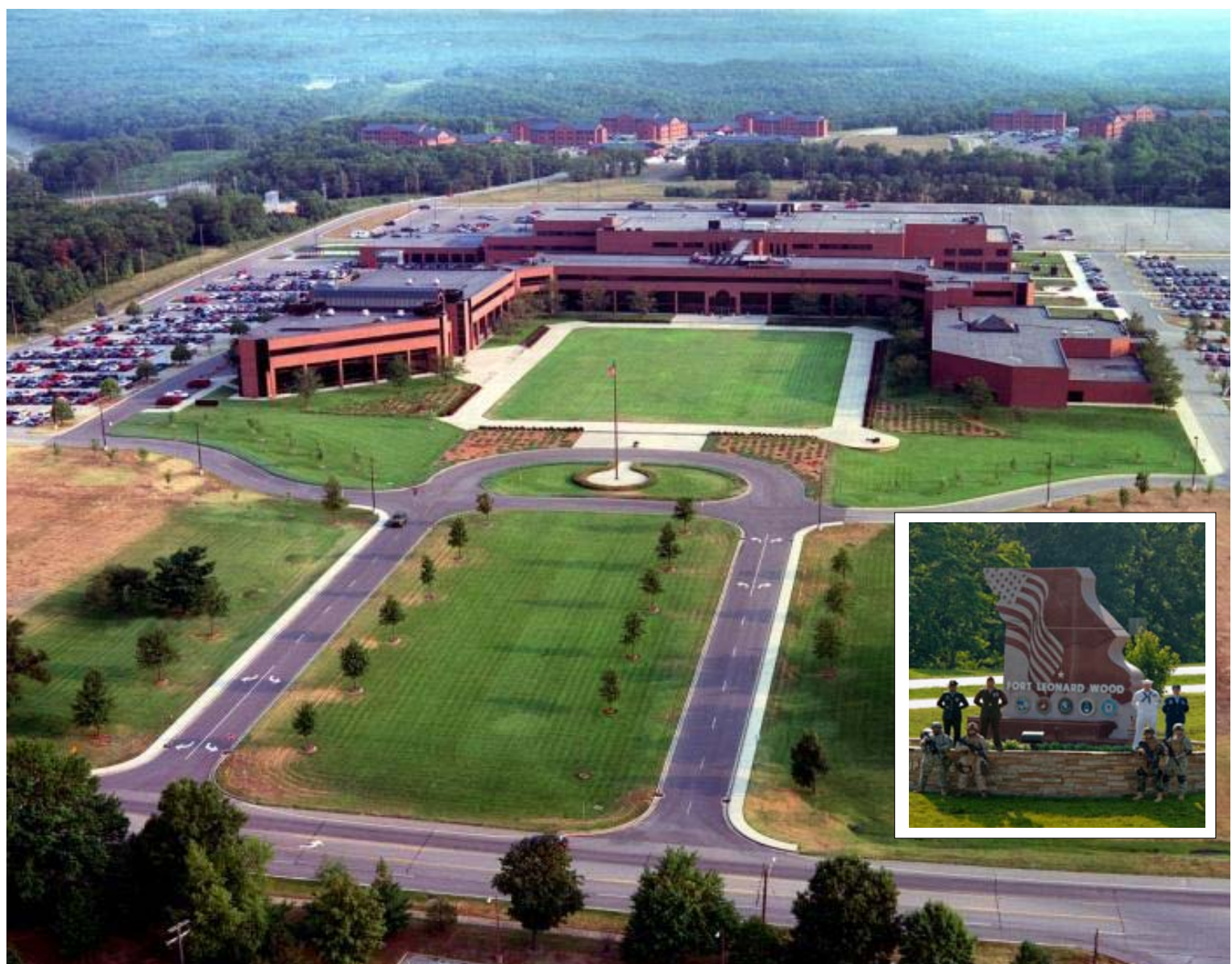





\section{Initial Integrated Strategic Sustainability Plan for Fort Leonard Wood}

Sarah B. Nemeth, Annette L. Stumpf, and Susan J. Bevelheimer

Construction Engineering Research Laboratory

U.S. Army Engineer Research and Development Center

2902 Newmark Drive

Champaign, IL 61822

Kevin J. Palmer

The Center for Sustainable Solutions

2700 Vinton $C t$

Charlottesville VA 22901

Final report

Approved for public release; distribution is unlimited.
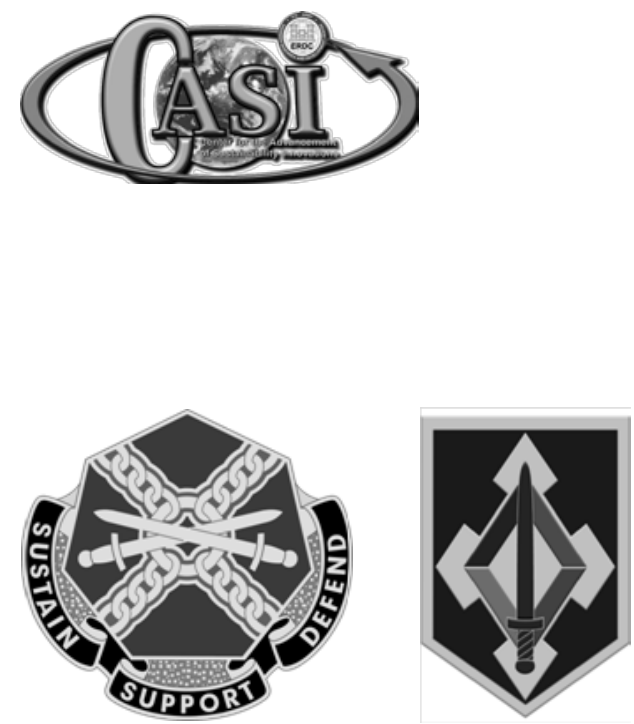

Prepared for US Army Garrison Fort Leonard Wood Fort Leonard Wood, MO 65473

Under FLWCTO Task No. PAIO-11-108-261, “Fort Leonard Wood Integrated Strategic Sustainability Plan" 


\section{Abstract}

The US Army recognizes its obligation to ensure that Soldiers have the land, water, and air resources needed to train; a healthy environment; adaptable facilities; and the support of local communities, government officials, and the American people. An Integrated Strategic Sustainability Plan (ISSP) was developed to ensure that US Army Garrison Fort Leonard Wood (FLW) can preserve these resources in order to continue meeting mission requirements in the future. This document represents the initial ISSP developed for FLW, a complex installation that fulfills multiple training requirements for the Army and other military commands. Developing a viable long-range ISSP requires significant participation by Garrison and Maneuver Support Center of Excellence personnel. Their contributions were facilitated through collaboration with contractors, the US Army Corps of Engineers, and Installation Management Command. The result was a working plan encompassing six strategic sustainability goals that align with FLW's six core business areas. The plan also includes related factors, such as action plans to guide and indicators to track FLW progress in meeting its goals. This ISSP will evolve as various objectives, action plans, and measures are refined. Team members will utilize online resources to facilitate development of the plan over its expected 25-year life cycle.

\section{The information and data presented in this document were cur- rent as of the end of FY11 (September 2011).}

DISCLAIMER: The contents of this report are not to be used for advertising, publication, or promotional purposes. Citation of trade names does not constitute an official endorsement or approval of the use of such commercial products. All product names and trademarks cited are the property of their respective owners. The findings of this report are not to be construed as an official Department of the Army position unless so designated by other authorized documents. 


\section{Table of Contents}

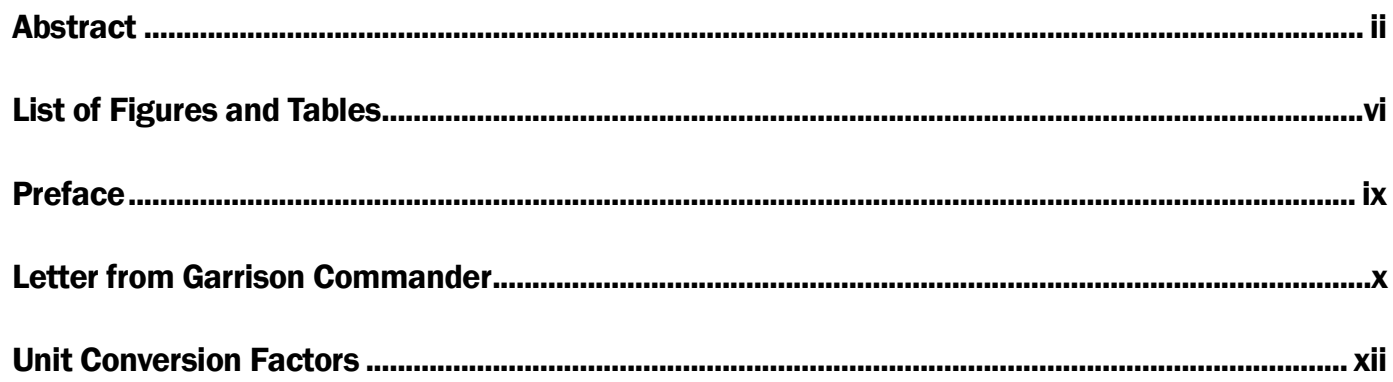

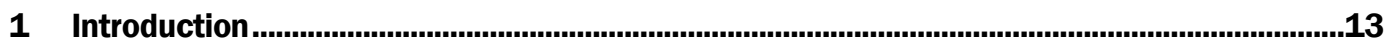

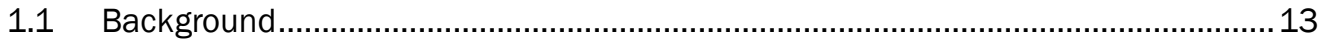

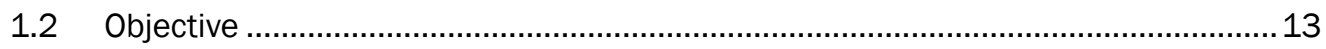

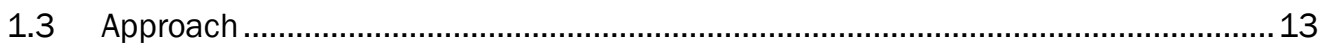

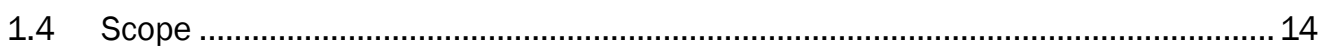

2 About Fort Leonard Wood ..........................................................................................................15

2.1 History of Fort Leonard Wood ......................................................................... 15

2.2 Installation growth and change ...................................................................... 18

2.3 Mission and vision statements ...................................................................... 19

2.3.1 Maneuver Support Center of Excellence ......................................................... 19

2.3.2 Installation Management Command .................................................................. 20

2.3.3 US Army Garrison Fort Leonard Wood ............................................................... 20

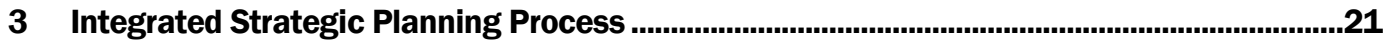

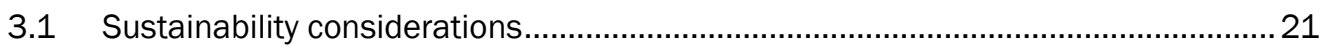

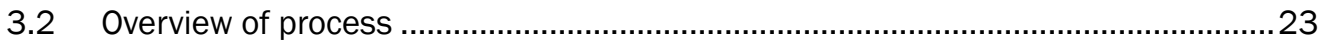

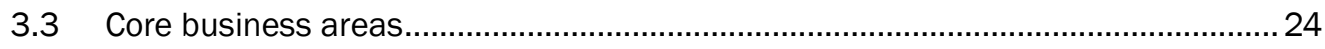

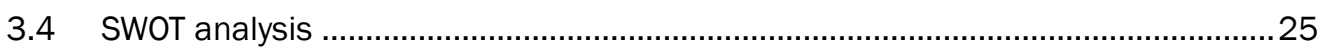

3.5 Strategic challenge statements ...................................................................... 25

3.5.1 Caring for Military, Civilians and Families Challenge Statement........................... 25

3.5.2 Community Engagement Challenge Statement \#1.............................................. 25

3.5.3 Community Engagement Challenge Statement \#2............................................... 26

3.5.4 Infrastructure Challenge Statement \#1................................................................ 26

3.5.5 Infrastructure Challenge Statement \#2 ............................................................. 26

3.5.6 Mission Services Challenge Statement ............................................................ 27

3.5.7 Training Challenge Statement........................................................................... 27

3.5.8 Workforce Challenge Statement ..................................................................... 27

3.6 Strategic management process...................................................................... 27

4 Strategic Goals.

4.1 Goal 1: Sustainable development and redevelopment at Fort Leonard Wood 30 


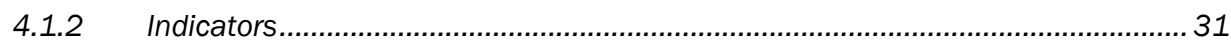

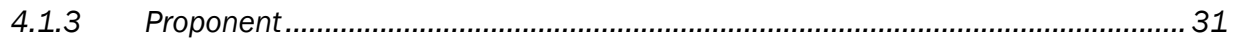

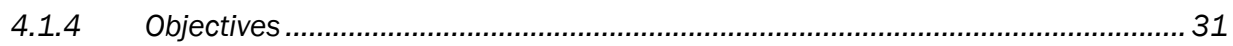

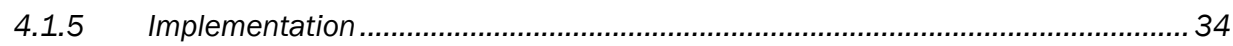

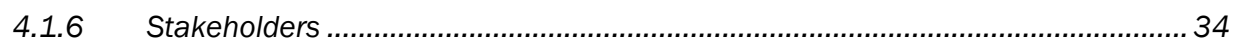

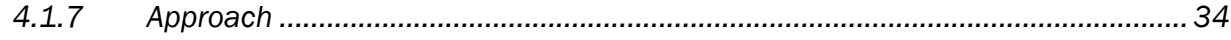

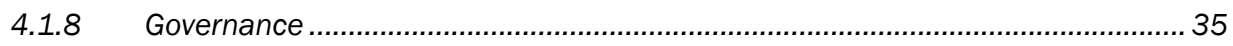

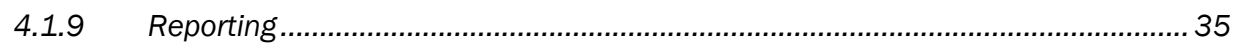

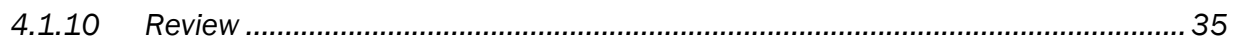

4.2 Goal 2: Organize and construct FLW with adequate manning, equipment, technology, and facilities to sustain mission services in support of the training

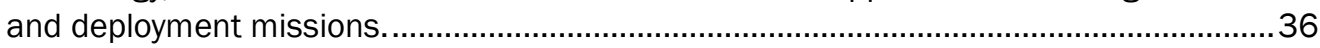

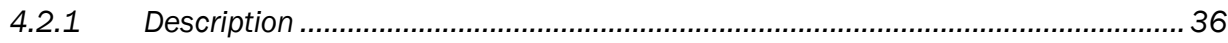

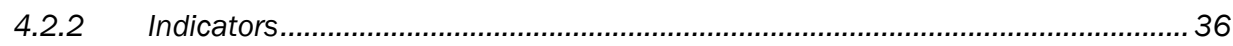

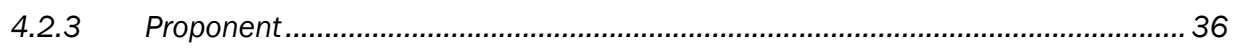

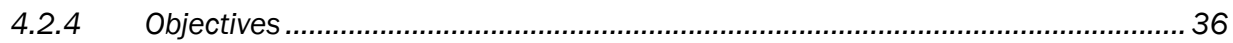

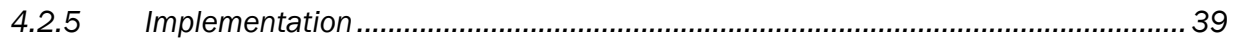

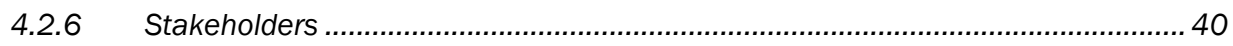

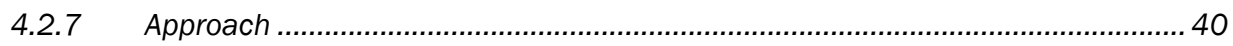

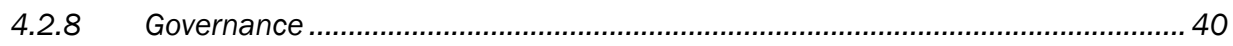

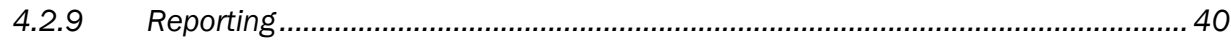

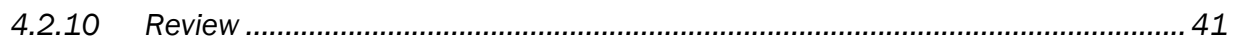

4.3 Goal 3: Full and effective community engagement ........................................... 41

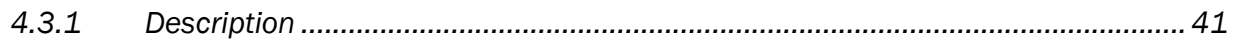

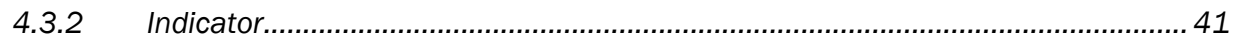

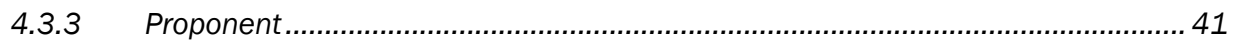

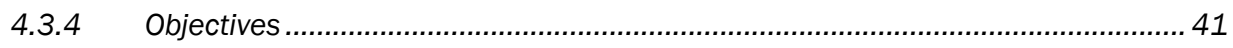

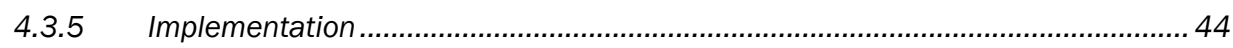

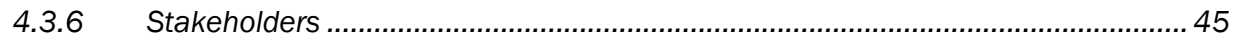

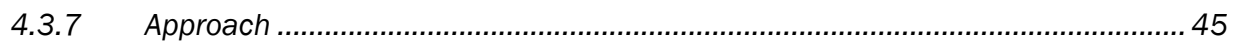

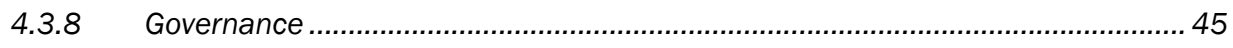

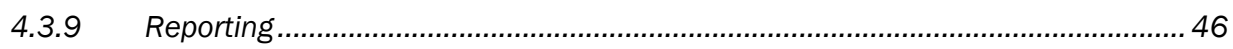

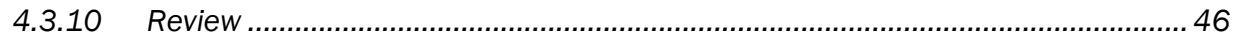

4.4 Goal 4: Service Members, Families, and Civilians resilient in mind, body, and spirit.

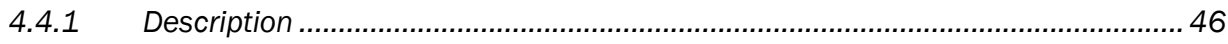

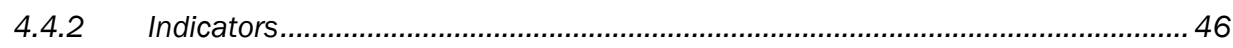

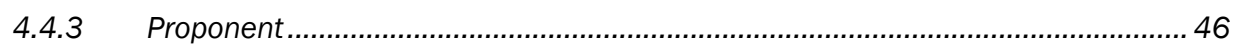

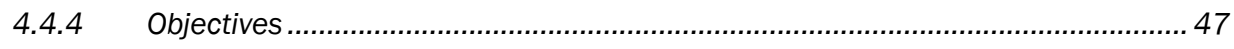

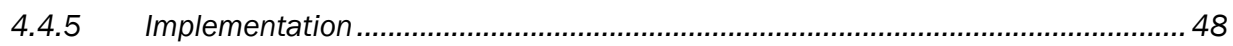

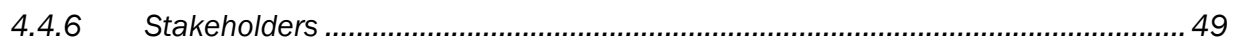

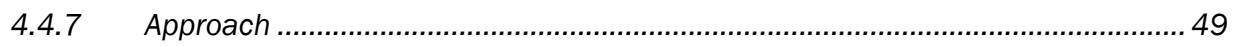

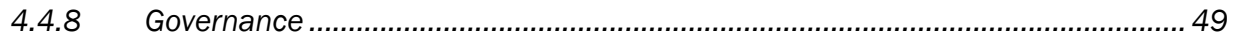

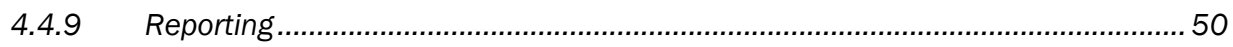

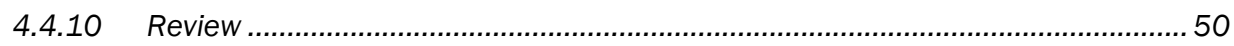

4.5 Goal 5: A culture of pride and trust throughout the Fort Leonard Wood workforce 


\begin{tabular}{|c|c|}
\hline .5 .1 & escription \\
\hline 1.5 .2 & ndicator.... \\
\hline 4.5 .3 & Proponent... \\
\hline 5.4 & Objectives.. \\
\hline 4.5 .5 & Implementation.. \\
\hline 4.5 .6 & Stakeholders. \\
\hline 4.5 .7 & Approach \\
\hline 4.5 .8 & Governance.. \\
\hline 4.5 .9 & Reporting........ \\
\hline 4.5.10 & \\
\hline
\end{tabular}

4.6 Goal 6: Modern, adaptable and high-performance training facilities, ranges, and land

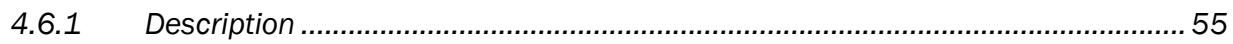

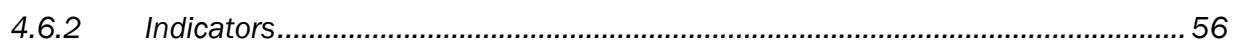

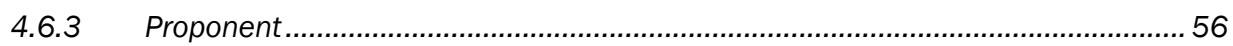

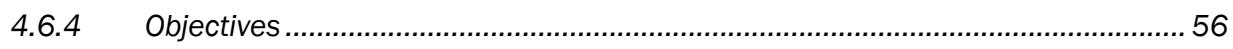

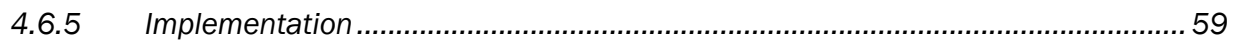

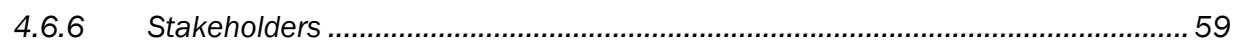

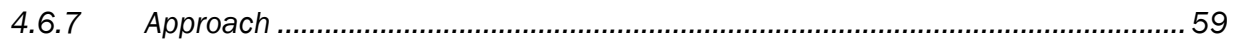

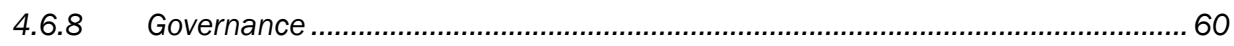

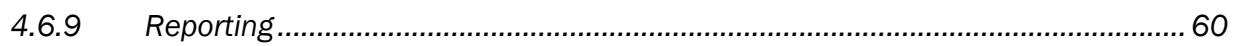

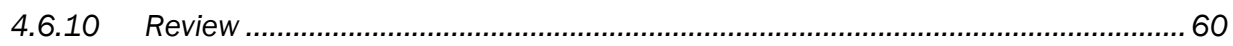

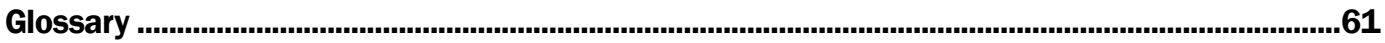

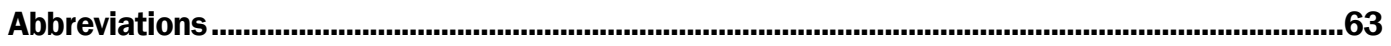

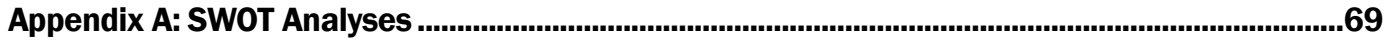

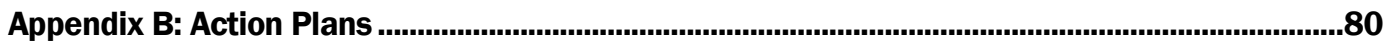

\section{Report Documentation Page}




\section{List of Figures and Tables}

\section{Figures}

Figure 1. Fort Leonard Wood provides all military services with training and support.

Figure 2. The Maneuver Support Center of Excellence at Fort Leonard Wood is an integral part of the US Army.

Figure 3. Installation Strategic Sustainability Plan logo for Fort Leonard Wood.

Figure 4. The Army Triple Bottom Line-Plus.

Figure 5. Fort Leonard Wood ISSP process and initial timeline.

Figure 6. SWOT analysis for Physical Fitness/Recreation. .70

Figure 7. SWOT analysis for Support Services...............................................................................

Figure 8. SWOT analysis for Spiritual/Relational Support. ............................................................... 71

Figure 9. SWOT analysis for Economic Development..................................................................... 71

Figure 10. SWOT analysis for Communication. ………………………………………………....

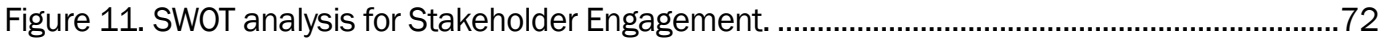

Figure 12. SWOT analysis for Marketing FLW.............................................................................73

Figure 13. SWOT analysis for Design/Build...............................................................................73

Figure 14. SWOT analysis for Operations/Renovate/Recycle......................................................... 74

Figure 15. SWOT analysis for Force Protection/Safety..................................................................... 74

Figure 16. SWOT analysis for Maintenance.............................................................................75

Figure 17. SWOT analysis for Transportation. ............................................................................

Figure 18. SWOT analysis for Training: Plan. ………………………………………………....

Figure 19. SWOT analysis for Training: Resources.........................................................................

Figure 20. SWOT analysis for Training: Execution..........................................................................77

Figure 21. SWOT analysis for Training: Assessment......................................................................7

Figure 22. SWOT analysis for Workforce: Training and Development................................................78

Figure 23. SWOT analysis for Workforce: Management. ....................................................................78

Figure 24. SWOT analysis for Workforce: Information/Communication.............................................79

Figure 25. SWOT analysis for Workforce: Benefits. ............................................................................

\section{Tables}

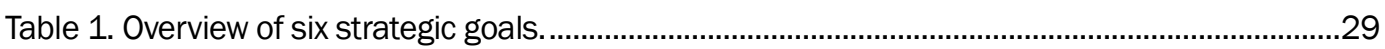

Table 2. Objective 1.1 - Building system standards. .......................................................................31

Table 3. Objective 1.2 - Energy management. .................................................................................32

Table 4. Objective 1.3 - Net-zero facilities. ……………….........................................................33

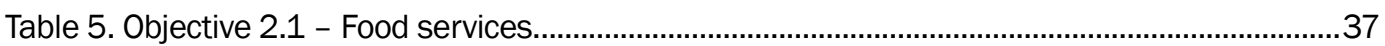

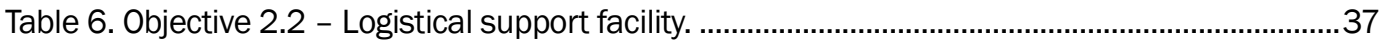

Table 7. Objective 2.3 - Deployment support. .....................................................................................38 
Table 8. Objective 2.4 - Service member processing. ………………………………...................38

Table 9. Objective 2.5 - Non-tactical vehicle fleet. ………..............................................................39

Table 10. Objective 3.1 - FLW quality of life..................................................................................42

Table 11. Objective 3.2 - Partnerships....................................................................................42

Table 12. Objective 3.3 - National media coverage. .......................................................................43

Table 13. Objective 3.4 - Community Engagement.........................................................................43

Table 14. Objective 3.5 - Regional sustainability initiative.....................................................................44

Table 15. Objective 4.1 - Installation Resiliency Campus...................................................................4

Table 16. Objective 4.2 - Educational opportunities....................................................................47

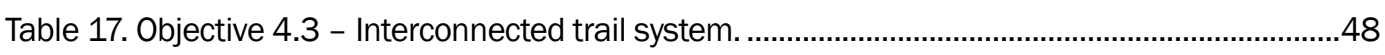

Table 18. Objective 4.4 - Fitness and wellness. ..........................................................................48

Table 19. Objective 5.1 - Community use of all employment services...............................................51

Table 20. Objective 5.2 - Provide skilled education to workforce.......................................................52

Table 21. Objective 5.3 - Workforce sustainability training.............................................................52

Table 22. Objective 5.4 - Employer of choice...............................................................................53

Table 23. Objective 6.1 - Training lands requirements. ...............................................................56

Table 24. Objective 6.2 - Facility and land acquisition conservation strategies................................57

Table 25. Objective 6.3 - Training lands and facilities for missions..................................................58

Table 26. Objective 6.4 - Protect training lands.........................................................................58

Table 27. Objective 1.1 Action Plan........................................................................................... 81

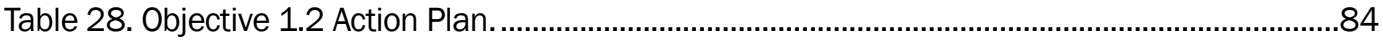

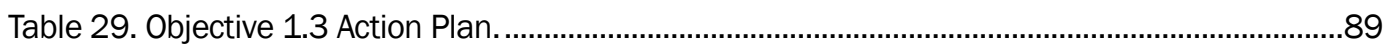

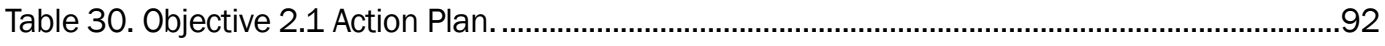

Table 31. Objective 2.2 Action Plan. ……………………............................................................93

Table 32. Objective 2.3 Action Plan.......................................................................................95

Table 33. Objective 2.4 Action Plan..............................................................................................

Table 34. Objective 2.5 Action Plan..........................................................................................97

Table 35. Objective 3.1 Action Plan. .............................................................................................98

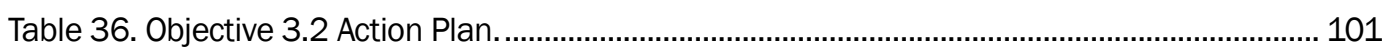

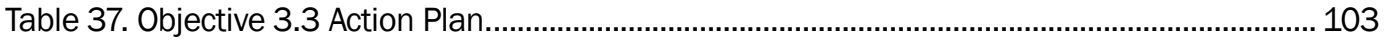

Table 38. Objective 3.4 Action Plan............................................................................................... 105

Table 39. Objective 3.5 Action Plan. .......................................................................................... 106

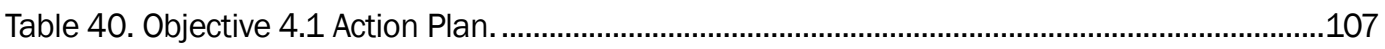

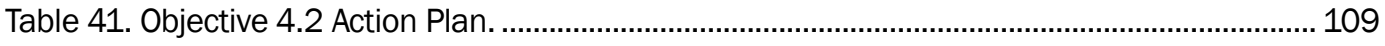

Table 42. Objective 4.3 Action Plan........................................................................................ 110

Table 43. Objective 4.4 Action Plan. ......................................................................................... 111

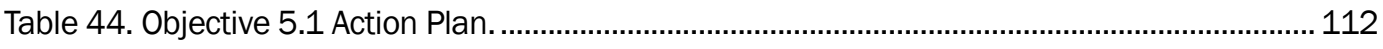

Table 45. Objective 5.2 Action Plan....................................................................................... 114

Table 46. Objective 5.3 Action Plan................................................................................................. 116

Table 47. Objective 5.4 Action Plan.......................................................................................... 118 


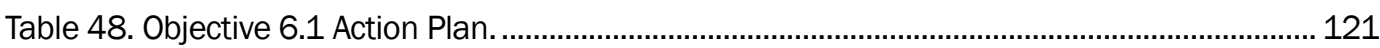

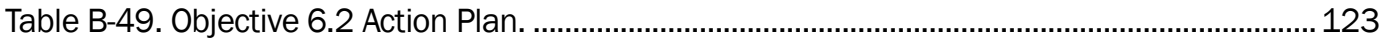

Table 50. Objective 6.3 Action Plan......................................................................................... 124

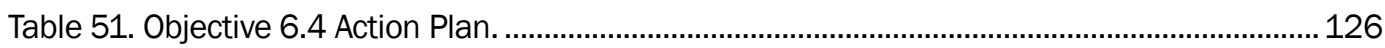




\section{Preface}

This study was conducted for the Plans, Analysis, and Integration Office (PAIO) at US Army Garrison Fort Leonard Wood (FLW) under FLWCTO Task No. PAIO-11-108-261, "Fort Leonard Wood Integrated Strategic Sustainability Plan.” The FLW technical monitor was Mr. Mark Premont, Chief of PAIO.

The work was performed by the Business Processes Branch (CN-B) of the Installations Division (CN), US Army Engineer Research and Development Center - Construction Engineering Research Laboratory (ERDC-CERL). The ERDC-CERL Principal Investigator was Ms. Susan Bevelheimer, CEERD-CN-B. Ms. Michelle Hanson was Chief, CEERD-CN-B; Mr. L. Michael Golish was Acting Chief, CEERD-CN; and Mr. William D. Goran was the Technical Director for Sustainable Programs and Director of the Center for Advancement of Sustainability Innovations (CASI). The Deputy Director of ERDC-CERL was Dr. Kirankumar Topudurti and the Director was Dr. Ilker Adiguzel.

This work would not have been possible without the direct contributions of the military and civilian personnel at FLW and the Maneuver Support Center of Excellence. Their input is the basis for this report, and the named authors who have recorded that input are deeply indebted to their dedicated efforts. The authors also recognize the valuable input and time given to help this plan by members of the community and other agencies who participated in the planning and development process.

COL Kevin J. Wilson is the Commander and Executive Director of ERDC, and Dr. J effery P. Holland is the Director. 


\section{Letter from Garrison Commander}

US Army Garrison Fort Leonard Wood is dedicated to providing the highest standards of support and services to the Military, Families, and Civilians who live and work on the Installation.

This plan is the initial roadmap that lays out strategy and metrics to track progress as part of a 25-year plan. It is a living tool to provide continuity and focus through mission and priority

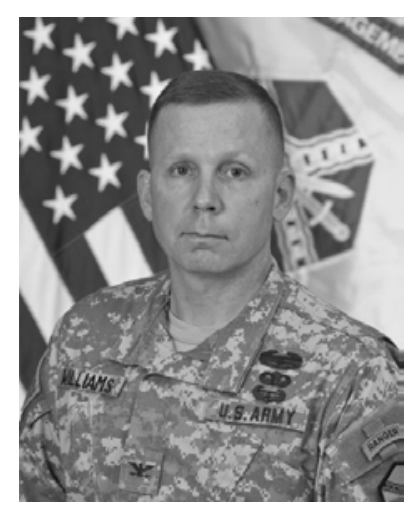
changes, and it builds in flexibility so that actions remain relevant. The ongoing economic environment makes it imperative that Army Installations operate in a cost environment, where every functional area is analyzed to ensure that it supports the mission and is not wasting resources.

The Garrison embraces the mission of the Installation Management Command (IMCOM) and supports the Maneuver Support Center of Excellence (MSCoE) vision.

IMCOM's Mission:

Our mission is to provide Soldiers, Civilians, and their Families with a quality of life commensurate with the quality of their service.

MSCoE's Vision:

Maneuver Support Center of Excellence, Fort Leonard Wood is the premier Army Center of Excellence where teams work innovatively to provide our Army integrated capabilities, professional warrior Soldiers, leaders, and forces who excel in the current operational environment and set conditions for success in future conflicts.

Efforts to provide effective and efficient services, programs, and infrastructure are even more important to the well-being and readiness of the 
Force due to the persistent conflicts, and the training and deployment tempo that place tremendous stress on the Force and Family members. In partnership with the MSCoE, our surrounding communities, academia, and industry, the US Army Garrison Fort Leonard Wood will continue to provide superior support to our Soldiers, Airmen, Marines, Navy, National Guard, Reservists, and their Families now and in the future.

CHARLES A. WILLIAMS

Colonel, US Army

Garrison Commander

US Army Garrison Fort Leonard Wood 


\section{Unit Conversion Factors}

\begin{tabular}{|l|c|l|}
\hline Multiply & By & To Obtain \\
\hline Acres & $4,046.873$ & square meters \\
\hline British thermal units (International Table) & $1,055.056$ & Joules \\
\hline Feet & 0.3048 & Meters \\
\hline gallons (U.S. liquid) & $3.785412 \mathrm{E}-03$ & cubic meters \\
\hline miles (U.S. statute) & $1,609.347$ & Meters \\
\hline square feet & 0.09290304 & square meters \\
\hline square inches & $6.4516 \mathrm{E}-04$ & square meters \\
\hline
\end{tabular}




\section{Introduction}

\subsection{Background}

The US Army recognizes its obligation to ensure that its Soldiers "have the land, water, and air resources needed to train; a healthy environment in which to live; and the support of local communities, government officials, and the American people." 1 To accomplish the level of sustainability required, the Army has developed multiple documents for Army installations to develop an Integrated Strategic Sustainability Plan (ISSP). In addition, Executive Order (EO) 13514 sets sustainability goals for Federal agencies to focus on improvements in environmental, energy, and economic performance.

US Army Garrison Fort Leonard Wood (FLW) is a highly complex installation that executes multiple training requirements for the Army and other military commands (see Chapter 2).

\subsection{Objective}

The objective of this work was to develop the initial version of a 25-year ISSP incorporating FLW's mission and vision with its energy, environmental, infrastructure, and resource planning into a long-term strategy to support the sustainability goals of the Army, the Department of Defense (DoD), and the Nation.

\subsection{Approach}

In November 2009, a presentation was made to FLW Senior Leadership. Next, through September 2011, a series of workshops focused on longterm FLW challenges and strategic goals; the objectives serving as intermediate end states and targets to attain the goals; action plans outlining the tasks and resources needed to achieve the objectives; and development of metrics for assessing progress toward each objective. More workshops were conducted later, and more will be scheduled as needed. Chapter 3 provides details about the integrated planning process.

\footnotetext{
1 From the 2008 Army Posture Statement, Army Sustainability, as reproduced in the Army Sustainability Report 2009. Available for download at www.aepi.army.mil.
} 


\subsection{Scope}

This work reports the initial results of a two-year effort by multiple stakeholders at FLW to develop the Installation's strategic sustainability goals, with action plans to achieve each goal's objectives.

This document reports the initial input provided at facilitated meetings with subject matter experts and stakeholders across FLW. This report documents the initial stages of the plan, presenting a snapshot of information that was current as of the end of FY11 (September 2011). However, integrated strategic planning is an ongoing and evolving process. Updates to the plan are maintained on the FLW Garrison Planning virtual team site of the Engineering Knowledge Online $\left(\mathrm{EKO}^{\circledR}\right)$ portal, hosted by the US Army Engineer Research and Development Center-Construction Engineering Research Laboratory (ERDC-CERL). 


\section{About Fort Leonard Wood}

Fort Leonard Wood is a major Army training base for DoD and a growing power-support platform. The Installation annually trains more than 80,000 military, and provides support for 7,000 military permanent party, 17,000 active duty family members, 9,000 civilians, and 55,000 retirees and family members. It also provides mobilization and demobilization capabilities and other support to its military units, the Army Reserve, and the Army National Guard. FLW is the home of the Maneuver Support Center of Excellence (MSCoE), which includes the US Army Chemical, Biological, Radiological, and Nuclear (CBRN) School, US Army Engineer School (USAES), and US Army Military Police School (USAMPS). FLW is also home to three gender-integrated Training Brigades, one of the five Reception Stations in the Army for newly accessed soldiers, and houses the largest Non-Commissioned Officers Academy (NCOA) in the Army.

The Installation also supports the military's largest interservice detachments from the Marine Corps, Navy, and Air Force. For serving these many functions well, the Installation prides itself as "The Station of Choice for Soldiers, Families, and Civilians."

\subsection{History of Fort Leonard Wood}

FLW history ${ }^{1}$ began just before World War II. With war engulfing Europe and much of Asia, the US government was increasing the size of the Armed Forces, procuring modern equipment, and merging the two into an effective fighting force. A major challenge was finding suitable training areas for the expanding Army. In 1940, the War Department decided to establish a major training facility in the Seventh Corps area. On 3 December 1940, military and state officials broke ground for what was known then as the Seventh Corps Area Training Center.

In early J anuary 1941, the War Department officially named the Installation in honor of Major General Leonard Wood, who served his country for 40 years. General Wood began his career as a contract surgeon during the

\footnotetext{
${ }^{1}$ The authors are indebted to the work of Dr. Larry Roberts, historian at Fort Leonard Wood, for much of the material in this section. His work was published in the Summer 2008 edition of Maneuver Support. http://www.wood.army.mil/engrmag/Maneuver\%20Support\%20Magazine/PDFs\%20for\%20Summer\% 202008/Roberts.pdf
} 
Apache Indian Wars in the 1880s, commanded the 1st US Volunteer Cavalry, popularly known as the Rough Riders, served as the Army Chief of Staff from 1910 to 1914, and was Governor General of the Philippine Islands after the Spanish-American War until his death in 1927.

Building FLW in the rugged terrain of Missouri's Ozark Mountains was a formidable challenge due to the absence of direct rail service, lack of housing for thousands of construction workers, and a schedule calling for the first troops to arrive only weeks after the initial groundbreaking. Despite inclement weather, construction was completed by J une 1941, with nearly 1,600 buildings (over 5 million square feet of floor space) built in 6 months at a cost of $\$ 37$ million.

FLW originally was to be the home of the 6th Infantry Division; however, in time, four other infantry divisions - the 8th, the 70th, the 75th, and the 97th-also trained at the Installation along with a number of nondivisional units. During World War II, more than 300,000 Soldiers were trained at FLW. The initial mission as an infantry division training area also was quickly expanded to include engineer training. Immediately after World War II, however, training drastically declined at FLW and ceased completely in the spring of 1946. Much of the military reservation was leased to an Oklahoma rancher who used the area for grazing cattle.

FLW was reactivated in 1950 in response to the Koran conflict and has continued to train Soldiers for a variety of deployments, as outlined below.

- Korea. The Army reopened FLW on 1 August 1950 to provide basic and engineer training for Soldiers destined for Korea. The Army reactivated the 6th Armored Division and gave the division the training mission as the cadre unit.

- Cold War. Demands and aggressive efforts by local community leaders led the establishment of FLW as a permanent Installation. In 1956, the Installation was designated the US Army Training Center - Engineer. Substantial funds were expended to replace the temporary wooden World War II-era buildings with permanent brick structures, positioning the post to handle the significant increase in training requirements arising from the war in Vietnam.

- Vietnam. In 1967, FLW provided 120,000 Soldiers with their basic, engineer, or skill (e.g., clerks, cooks, bakers, wiremen, mechanics, motor vehicle operators) training. Following the Vietnam War, the overall 
number of Soldiers training at the post declined. By the mid-1970s, the Air Force and Marine Corps began training their construction equipment operators at FLW. The post also began providing engineer training to other nations. By 1982, the 4th Training Brigade was training engineers from 15 foreign countries. In 1988, the Installation picked up the mission for all Army motor transportation training.

- Engineer School. In 1985, USAES began its move to FLW. This move was completed in 1989, with the school occupying a new $\$ 60$ million state-of-the-art training and education facility. For the first time in almost 50 years, all engineer training -including officers, warrant officers, noncommissioned officers, and enlisted personnelwould take place at the same location. This expansion required even more construction, including new commissary, fitness, and training facilities.

- Post-Cold War. FLW units were deployed to Southwest Asia for Operations Desert Shield (1990) and Desert Storm (1991). The Installation also processed over 4,000 Reserve Component Soldiers who were mobilized in response to the decision to invade Iraq, including 16 US Army Reserve and 9 Army National Guard units. FLW also provided personnel and technical expertise to contingency and humanitarian operations in Somalia, Haiti, and Bosnia, as well as instruction in engineer construction techniques for Navy, Air Force, and Marine Corps personnel.

- Military Police and Chemical Schools were relocated to FLW as a result of the 1995 Base Realignment and Closure (BRAC) decision to close Fort McClellan, Alabama. A three-story general instruction facility was added to the existing Engineer School building to house USAMPS and the renamed Chemical, Biological, Radiological, and Nuclear (CBRN) School at FLW. This new facility included state-of-the-art technology, support facilities, and administrative offices for both schools, as well as an addition to the existing Engineer Museum and specialized training facilities. In 1999, USAMPS and CBRN joined the Engineer School to form the MSCoE.

- War on Terrorism. FLW response to the 11 September 2001 attacks on the United States included revising doctrine and tactics to address asymmetric threats and also building or improving equipment to support forces from both the Active Army and Reserve Components. 


\subsection{Installation growth and change}

As described above, FLW has flexed and reinvented itself many times in response to the Nation's changing military needs. At this time, there is a significant interservice, international, and interagency presence at FLW. Such groups include the largest Marine detachment not located on a Marine Base, the largest Air Force detachment not on an Air Force Base, and trainees from all over the world (Figure 1). In October 2009, the FLW Maneuver Support Center was recognized as an integral part of the Army and was renamed the Maneuver Support Center of Excellence (Figure 2).

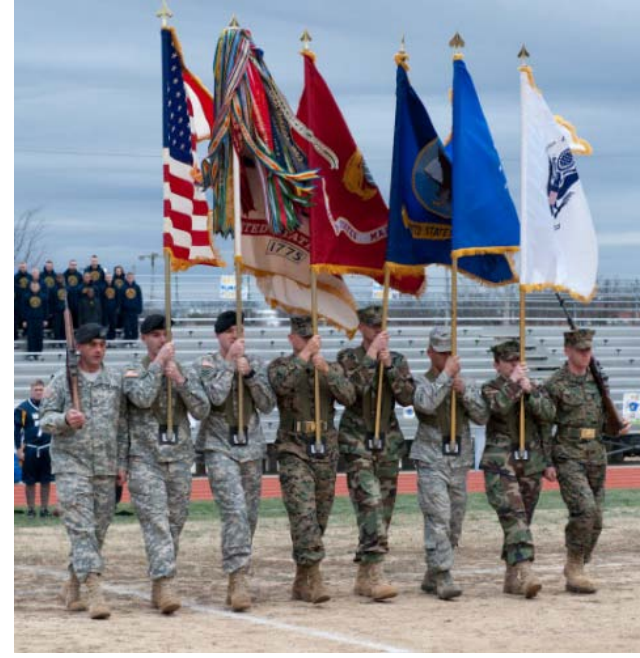

Figure 1. Fort Leonard Wood provides all military services with training and support.

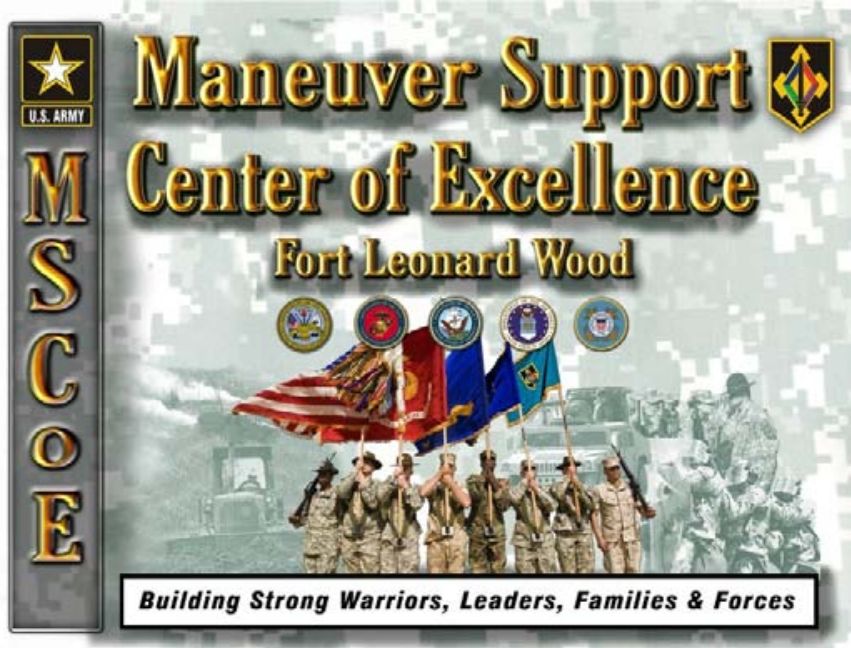

Figure 2. The Maneuver Support Center of Excellence at Fort Leonard Wood is an integral part of the US Army.

Facility construction continues at FLW, with over $\$ 1$ billion in projects approved or planned for the next 5 years. Other key actions taken to represent growth and change at FLW include the following:

- Prime Power School moved to FLW in 2010; building is certified LEED ${ }^{1}$ Gold

- Warrior Transition Unit (WTU); 83 Members WTU, 14 wounded in combat

- New Townhouse Single-Soldier Homes

- Residential Communities initiative

- General Leonard Wood Army Community Hospital Expansion and Access to Care initiative

\footnotetext{
1 LEED: Leadership in Energy and Environmental Design.
} 
- Truman Education Center (sixth largest degree-awarding program in Missouri)

- Army Family and Community Covenant Programs (with Lebanon, Pulaski County, Rolla, Sedalia, St. J ames, Cabool, Warrensburg, Columbia, St. J oseph, Savannah, Waynesville, Mountain Grove, Springfield, St. Louis, Branson, and the State of Missouri)

- Strategically Planning for Sustainability and Our Future initiative

- A technology park licensed to the University of Missouri for technical and industrial development

- Supporting expeditionary forces with 3 miles of four-lane highway to Interstate 44, a rail system consisting of 27.84 miles of track, and the Waynesville Regional Airport at Forney Field (a Class A airport on the southwest perimeter of the cantonment area).

\subsection{Mission and vision statements}

\subsubsection{Maneuver Support Center of Excellence}

Mission Statement

The Maneuver Support Center of Excellence develops Leaders and Warriors; advances Engineer, Military Police, Chemical, Biological, Radiological, and Nucle$\operatorname{ar}(\mathrm{CBRN})$ and Maneuver Support capabilities to ensure success in the current and future operational environments; sets conditions for training, readiness, deployment, reconstitution, and sustainment of all tenant forces. On order, deploys the 4th Maneuver Enhancement Brigade to conduct CBRN Consequence Management operations in support of ARNORTH's J TF Civil Support.

Vision

The Maneuver Support Center of Excellence, Fort Leonard Wood is the premier Army Center of Excellence where teams work innovatively to provide our Army integrated capabilities, professional warrior Soldiers, leaders, and forces who excel in the current operational environment and set conditions for success in future conflicts. 


\subsubsection{Installation Management Command}

Mission Statement

Our mission is to provide Soldiers, Civilians, and their Families with a quality of life commensurate with the quality of their service.

Vision

Army Installations are the Department of Defense standard for infrastructure quality and are the provider of consistent, quality services that are a force multiplier in supported organizations' mission accomplishment, and materially enhance Soldier and Family well-being and readiness.

\subsubsection{US Army Garrison Fort Leonard Wood}

Mission Statement

A values-based organization that provides quality Base Operation Services, Facilities, and Infrastructure to enable all units to accomplish their mission; to enhance the well-being of our Fort Leonard Wood community.

Vision

The Station of Choice for Soldiers, Families and Civilians. 


\section{Integrated Strategic Planning Process}

This ISSP will serve as a roadmap as FLW continually adapts and improves its support systems to meet future demands (Figure 3). The plan establishes concepts and methodologies that will improve Installation capabilities, infrastructure, and technologies to accomplish current and future missions. Support services at FLW must be robust enough to adapt to the operational tempo (OPTEMPO) of the various units and commands without losing focus on the well-being of Soldiers, Families, and all members of the FLW community.

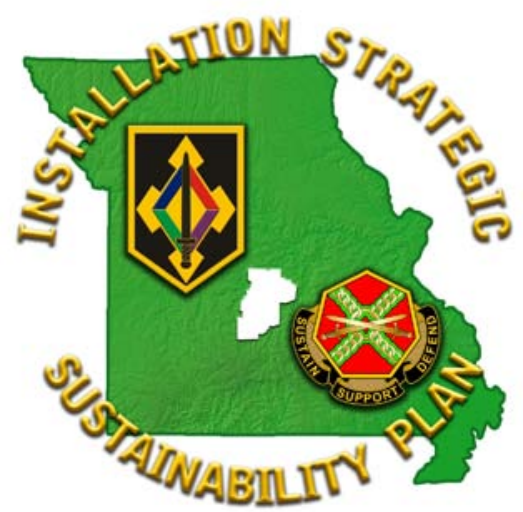

Figure 3. Installation Strategic Sustainability Plan logo for Fort Leonard Wood.

\subsection{Sustainability considerations}

The Department of the Army (DA) defines sustainability as "meeting current and future mission requirements worldwide while safeguarding human health, improving quality of life, and enhancing the natural environment."1

The concept of sustainability as it applies to IMCOM operations and Installation readiness takes on an additional meaning when described from a generational perspective. Simply put, sustainability means managing all resources-workforce, infrastructure, funds, information, natural resources, energy, and systems - to be available as needed for supporting current and future mission requirements.

\footnotetext{
1 "The Army Strategy for the Environment: Sustain the Mission, Secure the Future," p 4. Available for download at: http://www.sustainability.army.mil/overview/ArmyEnvStrategy.pdf.
} 
Creating a sustainable Installation will require changes in planning, investment, and Installation operations. It means identifying approaches, technologies, and systems that will best support the mission, improve the quality of life in military communities, protect resources, and reduce operational costs.

The process of integrating the Army's Triple Bottom Line-Plus (Figure 4) into the Garrison's strategic plan will accomplish the following objectives.

- Create ownership of the strategic plan, goals, and action plans among Installation staff by engaging a broader group of stakeholders throughout the development process.

- Develop 25-year goals that will support development of an enduring Installation through sustainable development and operation.

- Engage with community stakeholders throughout the process to better understand community needs and to illuminate Installation needs from the community. This interaction should strengthen existing relationships with and support from community partners.

- Build a roadmap for long-term changes that will optimize current and future missions, promote development of a sustainable community inside and outside the fenceline, and protect resources to ensure their availability for current and future missions.

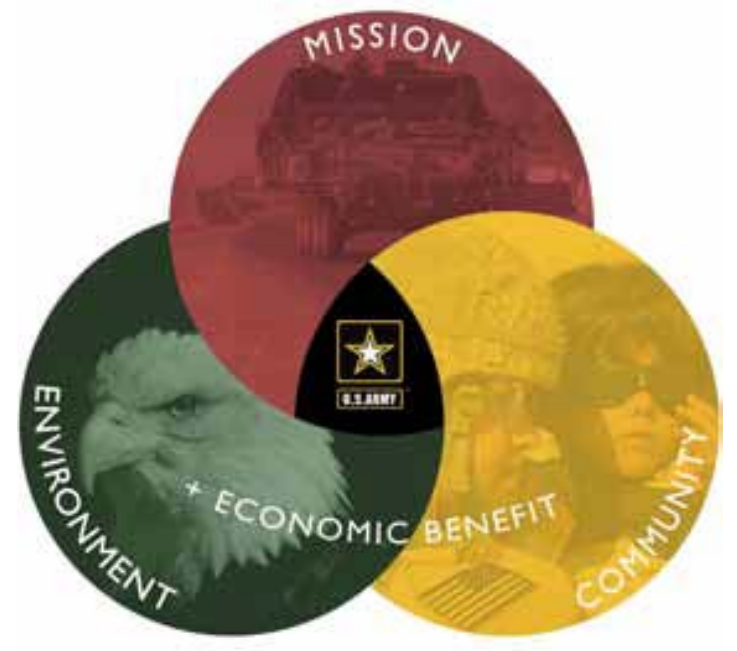

Figure 4. The Army Triple Bottom Line-Plus.

The principles of sustainability emphasize a long-term strategic perspective and underscore the fact that an Installation is not an "island," but is part of a regional environmental, economic, and social system. This plan 
meets that intent by reaching beyond the fenceline to look at regional issues and trends that could impact future missions. The principles of sustainability provide a compass for existing management programs and the vision to move beyond a reactive posture. Sustainability is the "end," but the "ways" and "means" to accomplish sustainability will come from individual and collaborative efforts associated with this plan and other supportive plans, both on and off the Installation.

\subsection{Overview of process}

The ISSP process at FLW began in 2009 to provide an updated strategic plan that would reflect the Army's push toward sustainable Installations. It began with the presentation to the Senior Leadership in November 2009, and proceeded through September 2011 to develop a realistic plan for implementation.

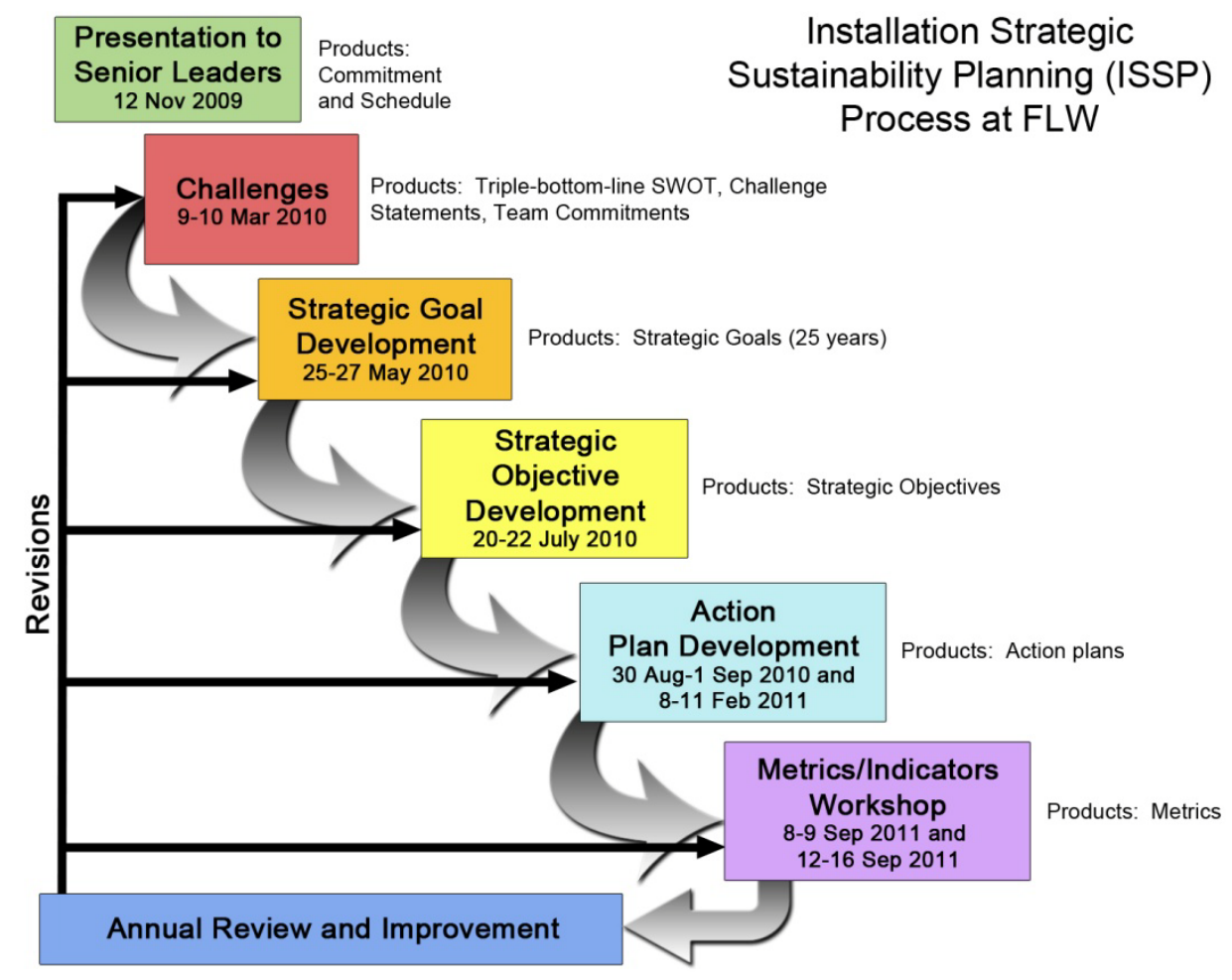

Figure 5. Fort Leonard Wood ISSP process and initial timeline.

The following methods were used to gather input for each part of this plan:

(1) The presentation to Senior Leadership provided FLW leaders and managers an overview of the ISSP process. This served to build understanding and support for the process from the Senior Commander, 
Garrison Commander, School Commandants, and all leaders in the Garrison and tenant organizations.

(2) The Challenges Workshop was held to identify core business activities critical to supporting the mission; to conduct a Strengths, Weaknesses, Opportunities, and Threats (SWOT) analysis; and to use the SWOT analysis to develop long-term challenge statements. A team leader and team members were established for each of the six core business areas during this workshop.

(3) The Goal-Setting Workshop developed long-term goals that addressed the issues described by the Challenge Statements written in the previous session.

(4) The Objectives Workshop provided the opportunity for leaders, program managers, and subject matter experts (SME) to define intermediate end states and targets that would move the Installation toward accomplishing the strategic goals.

(5) The Action Planning Workshop identified actions and resource requirements to begin accomplishing objectives previously identified. A later workshop to further refine the Action Plan was conducted in February 2011.

(6) The Metrics/Indicators Workshop focused on the development of metrics for assessing the progress toward each objective.

The results of these workshops are summarized in this report. In addition, Appendix A provides SWOT analyses for the Core Business Areas and Appendix B provides the detailed action plans developed by each team.

\subsection{Core business areas}

There are Six Core Business areas are aligned to the Garrison's mission. These represent the processes at which the Garrison must be successful to satisfy customers and fulfill its missions for higher headquarters. They are:

- Caring for Military, Civilians and Families

- Community Engagement

- Infrastructure (and Energy)

- Mission Services 
- Training Lands, Ranges, and Facilities

- Workforce Development.

\subsection{SWOT analysis}

The SWOT analysis is an important element of the ISSP process. Analysis was conducted by key Garrison staff, key customer group representatives, program managers, SMEs, and appointed action officers. The various analyses provided a situational or environmental scan of the Installation with an in-depth study of current internal strengths and weaknesses as well as external opportunities and threats. As part of the methodology of integrating sustainability with the Army's Triple Bottom Line-Plus, a SWOT analysis was conducted for each of the six Core Business Areas. The completed SWOT analyses (see Appendix A) served as a clear starting point to identify strategic challenges and build the ISSP.

\subsection{Strategic challenge statements}

Analysis of information in the SWOT matrices yielded recurring themes. These themes validated strategic challenges for the organization and targeted areas for action plan development. The strategic challenges for FLW are presented below.

\subsubsection{Caring for Military, Civilians and Families Challenge Statement}

Given that population is expanding, infrastructure is aging, new construction is encroaching on the environment, impacting quality of life (QOL) and Soldier/ Family readiness,

How will FLW continue to provide world-class training, programs, services, and facilities that make FLW the "Installation of Choice" and build strong Leaders, Soldiers, and Families?

\subsubsection{Community Engagement Challenge Statement \#1}

Given that there is no systematic Strategic Communication (STRATCOM) effort at FLW, specified priorities and messages are not approved, there is no method to push those messages forward, opportunity is lost to gain support for FLW, issues are lost with the change of command, communities are not supported consistently, and FLW's image is not properly represented, 
How will FLW develop a systematic STRATCOM effort that provides the command and the community the opportunity to advocate their position and issues to all markets and stakeholders in a way that improves FLW's relative to other installations?

\subsubsection{Community Engagement Challenge Statement \#2}

Given that FLW is remote from major communication outlets and is difficult to get to from places where there are major outlets, major communication vendors cannot easily access FLW, FLW is not easily able to draw outsiders to the area, and thus the FLW story is not getting out,

How will FLW connect to major communication outlets by either making FLW easier to get to or by starting a major TV network within 40 miles of the Installation?

\subsubsection{Infrastructure Challenge Statement \#1}

Given that FLW has historically utilized nonrenewable, relatively inexpensive, and abundant but vulnerable energy sources to support its mission, and further recognizing that the utilities and natural resources are constrained and increasingly costly,

How will FLW secure energy resources for future missionexpecting growth-in such a way as to limit availability and vulnerability risks, enhance environmental stewardship, and recognize relationships with privatized utilities and community partnerships?

\subsubsection{Infrastructure Challenge Statement \#2}

Given that FLW has limited land for operations, development of nearby private land constrains the Installation's land use, and environmental constraints limit usable land,

How will FLW not only secure future mission requirements, but also secure them in a way that will achieve maximum efficiency, enhance environmental quality, and optimize community relations? 


\subsubsection{Mission Services Challenge Statement}

Given the ever-changing demand for services, and with the current trend of reducing resources,

How will FLW achieve and maintain acceptable level of logistical, emergency, and human resources services for current and future support missions?

\subsubsection{Training Challenge Statement}

Given the limitations of an 86,000-acre training land shortfall, limited specialized manpower resources, limited funding for manpower and technology, and increasing range residue due to limited land utilization/access,

How will FLW provide a premier training environment that supports current training objectives and incorporates advancing technology; and how can FLW adapt to continual changes in operational environments to make the training capabilities located on FLW the best in the world?

\subsubsection{Workforce Challenge Statement}

Given there are workforce concerns related to potential hidden smallscale aging, family member employment, specialized skill recruiting (e.g., medical/ dental professionals and regimental-based professionals) and technical training,

How will FLW become a station of choice for military and civilian workers if the post's quality of life, jobs for family members, skills development, upward mobility, and professional challenges are not the best in the Nation?

\subsection{Strategic management process}

Performance reporting and updates to this plan will be made through an online automated system that is being developed. Installation governance will be integrated within the MSCoE Campaign Plan and within the Garrison's quarterly Performance Management Reviews and semiannual Installation Planning Boards. 
Annual azimuth checks will be conducted to ensure linkage and support for IMCOM, US Army Training and Doctrine Command (TRADOC), Department of the Army, and DoD initiatives. 


\section{Strategic Goals}

From the strategic planning process, FLW has developed six long-term strategic goals by building on the SWOT analyses and challenge statements for each of the six Core Business Areas. These goals target the significant issues that challenge the long-term viability of the Garrison to provide Military, Civilian, and Family members with the infrastructure, services, and programs necessary for mission accomplishment and QOL. Table 1 provides an overview of the strategic goals and related objectives.

Table 1. Overview of six strategic goals.

\begin{tabular}{|c|c|}
\hline Strategic Goals & Goal Objectives \\
\hline \multirow[t]{3}{*}{$\begin{array}{l}\text { Goal 1: Sustainable development and } \\
\text { redevelopment at FLW. }\end{array}$} & $\begin{array}{l}\text { Objective 1.1: Buildings in Campus setting that employ high-performance } \\
\text { and adaptable systems to progressively reduce the use of nonrenewable } \\
\text { resources. }\end{array}$ \\
\hline & $\begin{array}{l}\text { Objective 1.2: Efficient use and management of energy and water that is } \\
\text { provided from cost-competitive, secure, and renewable sources. }\end{array}$ \\
\hline & $\begin{array}{l}\text { Objective 1.3: By 2035, develop new and modernize existing facilities to } \\
\text { perform at net-zero with respect to energy, water, and waste while also } \\
\text { providing a high quality of life and adaptable work environment. }\end{array}$ \\
\hline \multirow{5}{*}{$\begin{array}{l}\text { Goal 2: Organize and construct FLW with } \\
\text { adequate manning, equipment, technology, and } \\
\text { facilities to sustain mission services in support } \\
\text { of the training and deployment missions. }\end{array}$} & Objective 2.1: Reduced footprint and optimized food service support. \\
\hline & $\begin{array}{l}\text { Objective 2.2: Efficiency through establishing an enterprise facility for } \\
\text { logistical support. }\end{array}$ \\
\hline & $\begin{array}{l}\text { Objective 2.3: Upgraded deployment support services and infrastructure } \\
\text { (rail heads, rail, staging areas, airfields, etc.). }\end{array}$ \\
\hline & $\begin{array}{l}\text { Objective 2.4: Efficiency through establishing an enterprise system for } \\
\text { service members' in- and out-processing. }\end{array}$ \\
\hline & $\begin{array}{l}\text { Objective 2.5: A Non-Tactical Vehicle fleet that provides optimum mission } \\
\text { and customer support at minimum cost, while taking full advantage of } \\
\text { emerging technologies to minimize negative impacts on the environment. }\end{array}$ \\
\hline \multirow[t]{5}{*}{$\begin{array}{l}\text { Goal 3: Full and effective community } \\
\text { engagement. }\end{array}$} & $\begin{array}{l}\text { Objective 3.1: Actively participate in the planning and execution of } \\
\text { regional, community, and economic development programs that enhance } \\
\text { the QOL for the greater FLW community. }\end{array}$ \\
\hline & $\begin{array}{l}\text { Objective 3.2: Leverage enduring partnerships with academia, industry, } \\
\text { and government to solve defense-related science and technology } \\
\text { challenges; establish FLW as a thriving national security center; and } \\
\text { promote regional, sustainable economic development. }\end{array}$ \\
\hline & $\begin{array}{l}\text { Objective 3.3: Facilitate consistent, positive national media coverage that } \\
\text { promotes FLW commands, missions, and expertise. }\end{array}$ \\
\hline & $\begin{array}{l}\text { Objective 3.4: Establish a regional partnership forum that promotes } \\
\text { outreach to local communities, inspiring community support. }\end{array}$ \\
\hline & Objective 3.5: Ozark Regional Sustainability Initiative. \\
\hline
\end{tabular}




\begin{tabular}{|c|c|}
\hline Strategic Goals & Goal Objectives \\
\hline \multirow{4}{*}{$\begin{array}{l}\text { Goal 4: Service Members, Families, and } \\
\text { Civilians: resilient in mind, body, and spirit. }\end{array}$} & Objective 4.1: Develop an Installation Resiliency ${ }^{1}$ Campus. \\
\hline & $\begin{array}{l}\text { Objective 4.2: Provide access to state-of-the-art, after-hours-accessible } \\
\text { classrooms and laboratories to improve all approved degree programs } \\
\text { and educational opportunities. }\end{array}$ \\
\hline & Objective 4.3: Construct diverse, interconnected trail system \\
\hline & $\begin{array}{l}\text { Objective 4.4: Develop, maintain, and sustain facilities and capabilities on } \\
\text { the Installation that support Soldier fitness and Family wellness. }\end{array}$ \\
\hline \multirow{4}{*}{$\begin{array}{l}\text { Goal 5: A culture of pride and trust throughout } \\
\text { the FLW workforce. }\end{array}$} & Objective 5.1: FLW community fully utilizes employment services. \\
\hline & $\begin{array}{l}\text { Objective 5.2: Provide opportunities and encouragement for technical } \\
\text { knowledge certification, degrees, ongoing training, and licensing for the } \\
\text { workforce (through posted training events, partnerships, and tenants, } \\
\text { etc.) to sustain a professional, skilled workforce best positioned to } \\
\text { support the mission. }\end{array}$ \\
\hline & $\begin{array}{l}\text { Objective 5.3: Develop a workforce with strong leaders, continuity, and } \\
\text { cross-functional support that builds unstoppable momentum for safe and } \\
\text { sustainable use of land, energy (fuel and electricity), and materials. }\end{array}$ \\
\hline & $\begin{array}{l}\text { Objective 5.4: Become an enlightened employer of choice that sustains a } \\
\text { workforce that is adaptable, dynamic, collaborative, motivated, and } \\
\text { functions sustainably in meeting current and future mission needs. }\end{array}$ \\
\hline \multirow[t]{4}{*}{$\begin{array}{l}\text { Goal 6: Modern, adaptable and high } \\
\text { performance training facilities, ranges and land. }\end{array}$} & $\begin{array}{l}\text { Objective 6.1: Accurate, timely, and complete identification of training } \\
\text { facilities, ranges, and land requirements. }\end{array}$ \\
\hline & $\begin{array}{l}\text { Objective 6.2: Develop a plan and implement an acquisition strategy to } \\
\text { provide modern, adaptable, sustainable high-performance training } \\
\text { facilities on FLW for all training requirements. }\end{array}$ \\
\hline & $\begin{array}{l}\text { Objective 6.3: Operate, modernize, and sustain training land, ranges, and } \\
\text { facilities to meet mission requirements (SR4-2). }\end{array}$ \\
\hline & $\begin{array}{l}\text { Objective 6.4: Protect and preserve training lands for current and future } \\
\text { missions. }\end{array}$ \\
\hline
\end{tabular}

Each goal is discussed below, with additional detail on objectives provided in table form. Action plans for each goal and its supporting objectives are provided in Appendix B. Note that the indicators were established during the ISSP process, but they will be continuously refined because they are crucial to measuring progress toward the 25-year goals.

\subsection{Goal 1: Sustainable development and redevelopment at Fort Leonard Wood}

\subsubsection{Description}

In the next 25 years, transform into an Installation with an efficient network of high-performance, sustainable, and resilient infrastructure systems, enabling mission assurance and mission expansion.

1 Resiliency is defined as the ability to bounce back from difficulty. 


\subsubsection{Indicators}

- Annual vehicular miles traveled on-post per person

- Percentage of buildings meeting net-zero standard (energy, water, waste)

- Reduced energy intensity

- Reduced water use intensity

- Fossil fuel use per person.

\subsubsection{Proponent}

\section{Directorate of Public Works (DPW Master Plans, Energy Manager)}

\subsubsection{Objectives}

Objectives for Goal 1 are shown in Table 2 - Table 4.

Table 2. Objective 1.1 - Building system standards.

\section{Objective 1.1: Buildings in Campus setting that employ high-performance and adaptable systems to progressively reduce the use of nonrenewable resources.}

Description: A community of smartly placed buildings in a campus setting that best supports the mission, which will occur while the following takes place:

- Minimizing on-post vehicle use

- Reducing the loss of training land to cantonment area development

- Taking advantage of on-post renewable power generation

- Using distributed energy micro-grids

- Maximizing accessibility to services and creating a pedestrian-friendly FLW community

\begin{tabular}{|c|c|}
\hline Lead Organization: DPW & $\begin{array}{l}\text { Requirements: IR1-4, EN2-1, EN2-2, EN2-3, EO } \\
\text { 13514 §2(g)(i), EO 13514 §2(g)(vii), EISA §438, EO } \\
13514 \text { [§2(g)(iv)], E013514, §2(g)(v), IR3-1, IR3-2, } \\
\text { IR3-3, IR3-4, IR5-1, E0 13514 § 2(g)(vi). }\end{array}$ \\
\hline $\begin{array}{l}\text { Leading Measure(s): } \\
\text { - Community density rating (LEED-like community } \\
\text { score) }\end{array}$ & $\begin{array}{l}\text { Lagging Measure(s): } \\
\text { - Density of buildings/acre of cantonment (sq ft } \\
\text { of building/area of space zoned for develop- } \\
\text { ment) } \\
\text { - Number of non-tactical vehicle miles traveled }\end{array}$ \\
\hline
\end{tabular}

Next Step(s):

- Revise installation Master Plan. Step will be initiated in January 2012 and completed by 2013.

Target(s):

- Update Master Plan by 4Q FY13

- Complete Master Plan Programmatic Environmental Assessment

- Beginning in 2012 all major new facilities will be constructed within approved development zones

- Survey and plan for eliminating old, underutilized facilities 
Objective 1.1: Buildings in Campus setting that employ high-performance and adaptable systems to progressively reduce the use of nonrenewable resources.

FTEs Required:

- 1.2 FTE to support sustainable development and transportation FY12-36

Funding Required:

- \$300k in FY12 to develop sustainable master plan (visioning)

- $\$ 550 \mathrm{~K}$ in FY12 Capital Improvement Strategy (Facilities Baseline), and storm water plan

- \$250K in FY13 for transportation plan

- $\$ 250 \mathrm{k} / \mathrm{yr}$ in FY13 and FY14 for Environmental Assessment.

Table 3. Objective 1.2 - Energy management.

Objective 1.2: Efficient use and management of energy and water that is provided from cost-competitive, secure, and renewable sources.

Description: Institutionalize energy and water savings by using conservation procedures and technologies throughout FLW. FLW heats primarily with natural gas which is a nonrenewable source. There are also cost and security issues to consider with this energy source. FLW will develop an energy production and management portfolio that will:

- Provide a mix of purchased and self-produced, conventional and renewable energy sources

- Explore and pursue on-site power production that will support development of sustainable power generation and use patterns

- Be integrated into designed facilities that can use recovered heat from energy production

- Exploit renewable on-post power sources like bio-mass, solar, waste-to-heat, and co-generation

- Integrate micro-grids into future development as well as improved and efficient transmission technologies

- Support the evolution of Fort Leonard Wood to a net-zero Installation

- Reaching the goal of efficient use of energy (and water) must include education/outreach to all Soldiers, Families, civilians, and contractors

Lead Organization: DPW Energy Manager

Requirements: EN3-2, EN3-3, EPAct $2005 \S 103$, EPAct 2005 §203, EISA §431, E013514§2(a)(i), EO 13514§2(f)(iv), EN1-3, EN3-1, EO 13514§2(f)(iv)

Leading Measure(s):

- Number of facilities/year audited for energy and water conservation opportunities

\section{Lagging Measure(s):}

- Percentage of renewable power purchased/used

- Percentage reduction in energy consumption (density -MBtu per square foot, EN-1)

- Percentage reduction in water consumption (density gallons per square foot, EN-1)

Next Step(s):

- Arrange to collect energy monitoring data collected through metering to compile baseline

- Continue to install meters

- Include water meters for all new construction and renovations

Leading Target(s):

- All facilities metered for water and energy use by 2020

- All facilities audited for energy and water use reduction options by 2015

- Facilities then monitored on a schedule once every 4 years.
Lagging Target(s):

In compliance with EPAct $2005 \S 203$, increase renewables by:

- $3 \%$ in FY2007-2009

- $5 \%$ in FY 2010-2012

- $7.5 \%$ in FY 2013 
Objective 1.2: Efficient use and management of energy and water that is provided from cost-competitive, secure, and renewable sources.

FTEs Required: 0.7 FTE in 3Q FY11, approximately 3.0 FTE in 4Q FY11-3Q FY12, approximately 1.0 FTE in 4Q FY12-4Q FY15, 2.7 FTE in FY16, 0.5 FTE in FY17-19, and 2.7 FTE in FY20-36.

Funding Required: \$350k in FY11, \$790k in FY12, \$200k/yr in FY13-16, and \$100k/yr in FY17-36.

Table 4. Objective 1.3 - Net-zero facilities.

Objective 1.3: By 2030, develop new and modernize existing facilities to perform at net-zero with respect to energy, water, and waste while providing a high quality of life and adaptable work environment.

Description: Change the way we build and renovate buildings to insure that all future infrastructures are sustainable to the greatest extent technologically feasible, cost effective to maintain and operate, and eventually meet Army net-zero waste, energy, and water goals.

Lead Organization: DPW
Leading Measure(s):
- Percent of buildings that have been surveyed for
conformance with the High Performance Sustain-
able Building (HPSB) guiding principles
- Number of FLW staff (with responsibilities in con-
- struction) who are accredited in LEED (AP)
Percentage of square feet meeting Net Zero
Ready (future measure)

Requirements: IR1-4, EN2-1, EN2-2, EN2-3, EO 13514 §2(g)(i), EO 13514 §2(g)(vii), EISA §438, EO 13514 [§2(g)(iv)], E013514, §2(g)(v), IR3-1, IR3-2, IR3-3, IR3-4, IR5-1, EO 13514 \& 2(g)(vi).

\section{Lagging Measure(s):}

- Reduction in energy use intensity, water use intensity

- Runoff

- Reduction in waste disposal from source reduction, reuse, use of natural/degradable products, and increased recycling

Next Step(s):

- Identify staff and begin training to become LEED accredited

- Work with CERL to initiate HPSB surveys

- Baseline water, energy, and waste data

Leading Target(s):

- Design a high-performance building for one OMAfunded building in 2011 - continue to do a different type of OMA-funded construction each year through 2020

- Meet EISA requirements; incorporate Low-Impact Development

- Advanced, centrally monitored, utility metering on $90 \%$ of all facilities by 2020 (10\% per year)

- All new buildings will be LEED Gold by 2020

- Net Zero energy designed into all buildings for construction or modernization starting in FY 2030 as per EO 13514 §2(g)(i)

Lagging Target(s):

- Net Zero Waste by 2030

- Net Zero Water by 2030

- Net Zero Energy by 2030

- EISA targets for runoff

FTEs Required: 2 FTEs starting in 4Q FY11-FY36 for a sustainability engineer (LEED-accredited) and a sustainability coordinator (PAIO)

Funding Required: \$315K FY12

- \$95K FY13

- $\$ 25 \mathrm{~K} / \mathrm{YR}$ starting in FY12 for annual update conference

- Actions will identify additional investments to upgrade infrastructure - these will be integrated into subsequent POM budgets. 


\subsubsection{Implementation}

The current schedule for implementation of this goal is provided in Appendix B. The timeline includes a list of actions to support accomplishment of the objectives listed above. Appendix B also identifies the estimated resources (beyond those currently available) that are needed to implement each objective in support of the strategic goal.

The planning team developed initial resource estimates for the actions. These estimates are not complete, so they will continue to be developed and refined as the plan is implemented. The following general guidelines were used in preparing resource estimates.

- Estimates are being provided for new efforts or significant workload increases.

- If the teams thought that the action can be accomplished within existing resources, no new requirements are identified.

- If the team thought that the action could not be completed with existing personnel, a staff hours/ FTE estimate is provided.

- If the team thought that the action would be contracted or purchased, a dollar estimate is provided.

\subsubsection{Stakeholders}

\begin{tabular}{|ll}
\hline Fort Leonard Wood Stakeholders & \\
$\begin{array}{l}\text { Directorate of Public Works (DPW) - Master } \\
\text { Plans }\end{array}$ & DPW Environmental \\
DPW Engineering & Directorate of Resource Management (DRM) \\
DPW Energy & $\begin{array}{l}\text { Real Property Planning Board } \\
\text { MSCoE G-8 }\end{array}$ \\
$\begin{array}{l}\text { MSCoE Capability Development and } \\
\text { Integration Directorate (CDID) }\end{array}$ \\
$\begin{array}{l}\text { Off-Post Stakeholders } \\
\begin{array}{l}\text { US Army Corps of Engineers, Kansas City } \\
\text { District }\end{array}\end{array}$ & $\begin{array}{l}\text { US Army Corps of Engineers, Headquarters: } \\
\text { Zero Energy Design Demonstration }\end{array}$ \\
\hline
\end{tabular}

\subsubsection{Approach}

Two energy managers, a transportation planner, and LEED accredited engineer would spearhead the transformation of FLW into a sustainable community. Campus development, design, and construction of net-zero facilities will require the actions listed below: 
- Training of engineering staff to reach LEED accreditation

- Development of a multifaceted master plan that includes water resources, transportation, zoning, micro-grids, and a facilities utilization

- Changing the Installation approach toward design and construction of new buildings as well as renovation of existing facilities.

In order to develop secure and renewable energy, FLW will meter and monitor buildings energy and water usage, develop an Installation-wide system of facility control, conduct auditing of all facilities, and develop a portfolio of on- and off-post renewable and traditional power supplies.

\subsubsection{Governance}

The strategic sustainability plan is integrated into Line of Effort (LOE) 5 of the Senior Commander's Campaign Plan. As such, the goal proponent will be responsible for coordinating activity, providing periodic information as part the performance review of the Senior Commander's Campaign Plan, informing the Garrison Commander of progress, and providing progress data and information for the annual sustainability report (managed by the PAIO).

Additional oversight of the planning and development aspects of this goal will be provided through the Real Property Planning Board and the Installation Planning Board. Input to specific projects will be provided through design charrettes as well as future Master Plan revisions and updates.

\subsubsection{Reporting}

Progress briefings to the Senior Commander and the senior leaders on LOE 5 of the MSCoE campaign plan, which includes ISSP as Objective 5.2, are scheduled at the Senior Commander's Executive Sessions.

\subsubsection{Review}

FLW plans to eventually conduct annual reviews. However, in the short term, quarterly meetings will be conducted. 


\subsection{Goal 2: Organize and construct FLW with adequate manning, equipment, technology, and facilities to sustain mission services in support of the training and deployment missions.}

\subsubsection{Description}

Improve mission services through strengthened communication, collaboration, and coordination both internally and externally (tenants, other service providers, surrounding communities). Enhance capabilities to rapidly adapt to emerging technologies and changing force structure and doctrine to ensure sustainability. Reduce logistics footprint through facility and operational efficiencies.

\subsubsection{Indicators}

- A "Mission Services Support Footprint" which combines:

o cost of providing services per soldier-day supported

o space:

* square feet of facilities needed to accomplish services per soldier-day

* acres of real estate needed to accomplish services per soldierday

* labor hours needed to provide services per soldier-day

* transportation equipment hours per soldier-mile

- Mission Services Quality indicator that may use surveys in addition to existing sources (e.g., ICE, CDR's Facebook page and CG's website comments; CG's Brigade Commanders Luncheon; Semiannual Training Brief [SATB]).

\subsubsection{Proponent}

Directorate of Logistics (DOL)

\subsubsection{Objectives}

Objectives for Goal 2 are shown in Table 5 - Table 9. 
Table 5. Objective 2.1 - Food services.

\begin{tabular}{|l|l|}
\hline \multicolumn{2}{|l|}{ Objective 2.1: Reduced footprint and optimized food service support. } \\
\hline $\begin{array}{l}\text { Description: An integrated, Installation-wide initiative to determine and implement an optimal food } \\
\text { service support system for FLW that reduces operating costs and wastes, while providing efficient and } \\
\text { high-quality food services. }\end{array}$ & $\begin{array}{l}\text { Requirements: Installation Management } \\
\text { Campaign Plan (IMCP) IR3, EN1 }\end{array}$ \\
\hline $\begin{array}{l}\text { Lead Organization: DOL } \\
\text { Leading Measure(s): }\end{array}$ & $\begin{array}{l}\text { Lagging Measure(s): } \\
\text { - Number of separate dining facilities in opera- } \\
\text { tion (Feb 2011 baseline = 13) } \\
\text { Additional Measures: } \\
\text { - Number of Dining Facilities (DFACs) identified operating costs (per soldier; } 2010 \text { or } \\
\text { as underutilized }\end{array}$ \\
- Meals per day served vs. capacity & $\begin{array}{l}\text { Satisfaction survey results } \\
\text { Next Step(s): } \\
\text { - Define and document long-term needs as part of Master Plan Visioning process }\end{array}$ \\
\hline $\begin{array}{l}\text { Target(s): } \\
\text { - } 9 \text { DFACs by } 2015 \\
\text { - } 7 \text { DFACs by } 2018\end{array}$ & Target(s): TBD \\
\hline Resources Required: no additional requirements (Lean Six Sigma Study team) \\
\hline
\end{tabular}

Table 6. Objective 2.2 - Logistical support facility.

\section{Objective 2.2: Efficiency through establishing an enterprise facility for logistical support.}

Description: Create and establish a "state of the art" facility to better provide cost- and energy-efficient services to the customers and also provide more timely services without the need for unnecessary movement or delay. Create a "one stop" logistics facility which takes in all concerns of the FORSCOM/TRADOC/AMC/IMCOM commanders. SR2-2: Develop programs that help synchronize resources and requirements across the key ARFORGEN processes - Man, Equip, Train with a focus on installation support.

\begin{tabular}{|c|c|}
\hline Lead Organization: DOL & Requirements: IMCP SR 3, \\
\hline $\begin{array}{l}\text { Leading Measure(s): } \\
\text { - } 1391 \text { in place for facility }\end{array}$ & $\begin{array}{l}\text { Lagging Measure(s): } \\
\text { - Reduced footprint of logistical support facili- } \\
\text { ties/operations (space, energy, operating } \\
\text { costs) }\end{array}$ \\
\hline $\begin{array}{l}\text { Target(s): } \\
\text { Deployment center by } 2021 \text { and } \\
\text { Logistics Support Center by } 2026\end{array}$ & Target(s): TBD \\
\hline \multicolumn{2}{|c|}{$\begin{array}{l}\text { Next Step(s): } \\
\text { - Engage with other installations to better understand approaches, technologies, design of logisti- } \\
\text { cal support facilities - Forts Bragg, Benning. } \\
\text { - Explore Fort Future design for METL/deployment features }\end{array}$} \\
\hline \multicolumn{2}{|c|}{$\begin{array}{l}\text { FTEs Required: } 1200 \text { hours total (approx. } 0.7 \text { FTE) spread across FY11-FY19 } \\
\text { Funding Required: TBD (design and construction costs) }\end{array}$} \\
\hline
\end{tabular}


Table 7. Objective 2.3 - Deployment support.

Objective 2.3: Upgraded deployment support services and infrastructure (rail heads, rail, staging areas, airfields, etc.).

Description: Expand and upgrade the existing (or non-existent) air and rail facilities to provide costefficient and timely rapid deployment service support. Priorities include identifying locations for various tasks, equipment needed to complete the tasks and identifying funding resources to complete the requirement. Support IMCOM IR1-2: Strategic Mobility Infrastructure (SMI) that fully enables ARFORGEN deployment/redeployment cycles.

\begin{tabular}{|l|l|}
\hline Lead Organization: DOL & Requirements: IMCP SR 3, IR 1 \\
\hline $\begin{array}{l}\text { Leading Measure(s): } \\
\text { - Rail capacity/reliability (trains per week; cars } \\
\text { per day) }\end{array}$ & $\begin{array}{l}\text { Lagging Measure(s): } \\
\text { - Personnel throughput capacity } \\
\text { - Airfield capacity (types of aircraft, lifts) } \\
\text { - Capacity of staging areas }\end{array}$ \\
\hline $\begin{array}{l}\text { Target(s): } \\
\text { - First milestone- completion of deployment plan } \\
\text { by } 2012\end{array}$ & Target(s): TBD based on deployment plan \\
- Additional targets TBD based on plan & \\
\hline $\begin{array}{l}\text { Next Step(s): } \\
\text { - Baseline current capacity } \\
\text { - Evaluate deployment scenarios to create deployment plan/identify infrastructure needs to opti- } \\
\text { mize deployment capacity/capability. }\end{array}$ \\
\hline Resources Required: TBD (based on deployment plan) \\
\hline
\end{tabular}

Table 8. Objective 2.4 - Service member processing.

\section{Objective 2.4. Efficiency through establishing an enterprise system for service members' in- and out- processing.}

Description: Create and establish an automated enterprise system to provide a centralized in- and outprocessing service to the customers and also provide a more timely service without the need for unnecessary movement or delay.

\begin{tabular}{|l|l|}
\hline $\begin{array}{l}\text { Lead Organization: } \\
\text { Directorate of Human Resources (DHR) }\end{array}$ & Requirements: IMCP SR3 \\
\hline $\begin{array}{l}\text { Leading Measure(s): } \\
\text { - Ratio of virtual vs. face-to-face in/out pro- } \\
\text { cessing steps }\end{array}$ & $\begin{array}{c}\text { Lagging Measure(s): } \\
\text { - Number of days to in-/out-process }\end{array}$ \\
\hline $\begin{array}{l}\text { Next Step(s): } \\
\text { - Identify Soldier Readiness Process (SRP) to define targets from FY12 and beyond } \\
\text { - Review/Develop process flow diagram }\end{array}$ \\
\hline Target(s): See action plan (Appendix B) & $\begin{array}{l}\text { Target(s): TBD after baseline information } \\
\text { developed FY2012 }\end{array}$ \\
\hline Resources Required: TBD (may require new FTEs) \\
\hline
\end{tabular}


Table 9. Objective 2.5 - Non-tactical vehicle fleet.

Objective 2.5. A Non-Tactical Vehicle fleet that provides optimum mission and customer support at minimum cost, while taking full advantage of emerging technologies to minimize negative impacts on the environment.

NOTE: Objective 2.5 will be incorporated/evaluated in a Cost-Culture Study by the Garrison Commander. Actions and projects will be developed based on results of that study.

Description: Includes GSA fleet, MWR, commercial material handling equipment, and any nondeployable Army owned or leased self-propelled equipment.

\begin{tabular}{|l|l|}
\hline Lead Organization: DOL & Requirements: EN4-1, EN4-2, EN4-3 \\
\hline $\begin{array}{l}\text { Leading Measure(s): } \\
\text { - Reduced fleet size, increased miles/vehicle/yr }\end{array}$ & $\begin{array}{c}\text { Lagging Measure(s): } \\
\text { - Dollars spent to have/operate non-tactical } \\
\text { fleet }\end{array}$ \\
\hline $\begin{array}{l}\text { Next Step(s): } \\
\text { - Identify current non-tactical transportation }\end{array}$ \\
\hline $\begin{array}{l}\text { Target(s): } \\
\text { • } 400 \text { vehicles (46\%) by } 2012\end{array}$ & $\begin{array}{c}\text { Target(s): } \\
\text { - TBD }\end{array}$ \\
\hline Resources Required: TBD
\end{tabular}

\subsubsection{Implementation}

The current schedule for implementation of Goal 2 is provided in Appendix B. The timeline includes a list of actions to support accomplishment of the objectives listed above. Appendix B also identifies the estimated resources (beyond those currently available) needed to implement each objective in support of the strategic goal. The planning team developed initial resource estimates for the actions. These estimates are not complete, so they will continue to be developed and refined as the plan is implemented. The following general guidelines were used:

- Estimates are being provided for new efforts or significant workload increases.

- If the teams thought that the action can be accomplished within existing resources, no new requirements are identified.

- If the team thought that the action could not be completed with existing personnel, a staff hours/ FTE estimate is provided.

- If the team thought that the action would be contracted or purchased, a dollar estimate is provided. 


\subsubsection{Stakeholders}

\begin{tabular}{|c|c|}
\hline \multicolumn{2}{|l|}{ Fort Leonard Wood Stakeholders } \\
\hline DOL/Lean Six Sigma Team & G8 \\
\hline $\begin{array}{l}\text { Director Plans, Training and Mobilization } \\
\text { (DPTM) }\end{array}$ & $\begin{array}{l}\text { Family and Morale, Welfare and Recreation } \\
\text { (DFMWR) }\end{array}$ \\
\hline Directorate of Public Works & LGFS \\
\hline Directorate of Human Resources & PAIO \\
\hline G1 & $4^{\text {th }}$ Maneuver Enhancement Brigade (MEB) FLW \\
\hline Directorate of Resource Management & $\begin{array}{l}\text { All mission services, organizations, and } \\
\text { directorates. }\end{array}$ \\
\hline Network Enterprise Center (NEC) & All organizations that conduct in/out processing. \\
\hline \multicolumn{2}{|l|}{ Inter Service Review Organization } \\
\hline \multicolumn{2}{|l|}{ Off-Post Stakeholders } \\
\hline US Army Corps of Engineers (USACE) & FORSCOM HQ \\
\hline General Services Administration (GSA) & \\
\hline
\end{tabular}

\subsubsection{Approach}

The approach for this goal has yet to be determined.

\subsubsection{Governance}

The strategic sustainability plan is integrated into LOE 5 of the Senior Commander's Campaign Plan. As such, the goal proponent will be responsible for coordinating activity, providing periodic information as part the performance review of the Senior Commander's Campaign Plan, informing the Garrison Commander of progress, and providing progress data and information for the annual sustainability report (managed by the PAIO).

Additional needs for integration with other Installation and Garrison functions, standing committees and boards, and external meetings have not been identified at this time. Integration opportunities will be identified and documented as implementation proceeds.

\subsubsection{Reporting}

Progress briefings to the Senior Commander and the senior leaders on LOE 5 of the MSCoE campaign plan, which includes ISSP as Objective 5.2, are scheduled at the Senior Commander's Executive Sessions. 


\subsubsection{Review}

FLW plans to eventually conduct annual reviews. However, in the short term, quarterly meetings will be conducted.

\subsection{Goal 3: Full and effective community engagement}

\subsubsection{Description}

An effective and enduring strategic communications program that empowers and engages the Installation with the greater community and stakeholders to support mutual missions and efforts, and enhance jobs to make FLW the "station of choice."

\subsubsection{Indicator}

The process to develop this indicator includes identifying where partnerships between community stakeholders and FLW are critical, selecting a scoring for each issue, and creating a weighted indicator for the FLW goal based upon a composite score that represents progress (or lack of progress) in addressing these issues. The team identified the following topics as areas where partnerships are critical.

- Regional education

- Community safety

- Utilities

- Jobs

- Medical/health services

- Regional transportation
- Recreation

- Services - retail

- Housing

- Economic development

- Research and technology development

- Recreation.

\subsubsection{Proponent}

Plans, Analysis, and Integration Office (PAIO)

\subsubsection{Objectives}

Objectives for Goal 3 are shown in Table 10 - Table 14. 
Table 10. Objective 3.1 - FLW quality of life.

Objective 3.1: Actively participate in the planning and execution of regional, community, and economic development programs that enhance the $\mathrm{QOL}$ for the greater FLW community.

Description: Coordinated regional activities that define community direction, establishing regional development patterns, identifying and pursuing economic development that will improve quality of life in the region, and establishing forums where community stakeholders, including FLW, can work together to accomplish beneficial goals and objectives including:

- Economics

- Education

- Health Care and Social Services

- Housing
- Land Use

- Public Safety

- Transportation
Lead Organization: PAIO, State of Missouri DED, and Communities

Leading Measure(s):

- Number of relevant memberships in regional planning organizations.
Requirements: E013514§2(f)(i)

\section{Lagging Measure(s):}

- CG approves FLW Goal-team to work on economic development issues.

Next Step(s):

- Explore cooperation with regional planning organizations to develop a regional plan focused on Quality of Life.

- Explore combination of this objective with the Sustainable Ozarks Objective.

Target(s): Complete by Oct 2014

Resources Required: No additional resources

needed beyond those currently available

Table 11. Objective 3.2 - Partnerships.

Objective 3.2: Leverage enduring partnerships with academia, industry, and government to solve defenserelated science and technology challenges; establish FLW as a thriving national security center; and promote regional, sustainable economic development.

Description: Use partnerships effectively through policy and actions to enhance mission, support regional economic development, and support mission requirements that pose unique challenges to the Installation. Solidify partnerships with:

- The University of Missouri Technical Park

- The Leonard Wood Institute

- Missouri University of Science and Technology (Missouri S\&T)

- Park Service

\begin{tabular}{|c|c|}
\hline $\begin{array}{l}\text { Lead Organization: } \\
\text { - MSCoE, JIIM-IA }\end{array}$ & Requirements: IR4, SW4 \\
\hline $\begin{array}{l}\text { Leading Measure(s): } \\
\text { - Number of partnering agreements } \\
\text { - Number of enabling processes }\end{array}$ & $\begin{array}{l}\text { Lagging Measure(s): } \\
\text { - Presence in Tech Park of more acader } \\
\text { R\&D, and other government agencies } \\
\text { - Amount of funding }\end{array}$ \\
\hline \multicolumn{2}{|c|}{$\begin{array}{l}\text { Next Step(s): } \\
\text { - Document current partnerships and their function }\end{array}$} \\
\hline Target(s): Completed FY20. & $\begin{array}{l}\text { Resources Required: } \\
\text { - } 0.5 \text { FTE in STRATCOM in 3Q FY11-20. } \\
\text { - } \$ 300 \mathrm{k} / \mathrm{yr} \text { in FY11-20 }\end{array}$ \\
\hline
\end{tabular}


Table 12. Objective 3.3 - National media coverage.

Objective 3.3 FLW has consistent, positive, national media coverage that promotes FLW commands, missions, and expertise.

Description: Active communication that illustrates the importance of FLW to the Army, the State of Missouri, regional partners, and the local community.

\begin{tabular}{|l|l|}
\hline Lead Organization: PAO & Requirements: SW4, SR3 \\
\hline $\begin{array}{c}\text { Leading Measure(s): } \\
\text { - Funding and staff allocated to support }\end{array}$ & $\begin{array}{l}\text { Lagging Measure(s): } \\
\text { - Number of successful storylines picked up and } \\
\text { covered by national news outlets }\end{array}$ \\
\hline
\end{tabular}

Next Step(s):

- Complete STRATCOM

- Develop a list of targets and messages

Target(s):

- One news story per quarter to the Installation website about military life; highlight programs and services to assist Soldiers, Families and Civilians (SW4-5)

- Completed FY20.
Resources Required:

- 1.0 FTE in STRATCOM in 3Q FY11- 1Q FY12 and 1.0 FTE in PAO in 1Q FY12-14

- Funding Required:

- If the 2.0 FTEs not obtained, then $\$ 150 \mathrm{k} / \mathrm{yr}$ in FY11-12 for STRATCOM and another \$150k/yr in FY12-14 for PAO for contracted services.

Table 13. Objective 3.4 - Community Engagement.

Objective 3.4 A regional partnership forum that promotes outreach to local communities, inspiring community support. Community partnerships support the FLW mission and enhance stakeholder interaction (including Installation visits).

Description: Senior leadership participates in making presentations to additional regional partnerships and activities as a means for strengthening ties with the surrounding community.

\begin{tabular}{|l|l|}
\hline Lead Organization: PAO & $\begin{array}{l}\text { Requirements: SW2-4, SW4-1, SW4-2, SW4-3, SW4- } \\
\text { 4, SW4-5 }\end{array}$ \\
\hline $\begin{array}{l}\text { Leading Measure(s): } \\
\text { - Number of partnership activities }\end{array}$ & $\begin{array}{l}\text { Lagging Measure(s): } \\
\text { - Results of community support survey }\end{array}$ \\
\hline
\end{tabular}

Next Step(s):

- Coordinate with CG's community outreach to insure message is spread consistently and widely to stakeholder communities

- Identify and customize survey mechanism for following up with community stakeholders who receive a leadership briefing

- Develop sustainable Fort Leonard Wood leadership message slide set

Target(s):

- Establish by CY2012

- One civic meeting per quarter for each community support organization on a rotating basis to provide information on Installation issues or initiatives (SW4-3)

- Four civilian community briefings per year to provide an opportunity for Army leadership to share military quality of life issues with their communities (SW4-5)
Resources Required: No additional resources needed beyond those currently available. 
Table 14. Objective 3.5 - Regional sustainability initiative.

\begin{tabular}{|c|c|}
\hline \multicolumn{2}{|l|}{ Objective 3.5: Ozark Regional Sustainability Initiative. } \\
\hline \multicolumn{2}{|c|}{$\begin{array}{l}\text { Description: Establish an initiative to encourage and support sustainable development to the benefit of all } \\
\text { within the region. }\end{array}$} \\
\hline Lead Organization: PAIO & Requirements: IR4, IR6 \\
\hline $\begin{array}{l}\text { Leading Measure(s): } \\
\text { - Amount of funding for regional sustainability ef- } \\
\text { fort }\end{array}$ & $\begin{array}{l}\text { Lagging Measure(s): } \\
\text { - Local organization takes leadership role (will } \\
\text { define lagging measures for success with } \\
\text { stakeholders) }\end{array}$ \\
\hline \multicolumn{2}{|c|}{$\begin{array}{l}\text { Next Step(s): } \\
\text { - Establish effort to initiate and launch Sustainable Ozarks effort }\end{array}$} \\
\hline $\begin{array}{l}\text { Target(s): } \\
\text { Regional goals and charter established by the end of } \\
2012\end{array}$ & $\begin{array}{l}\text { Resources Required: } \\
\text { - } 0.2 \text { FTE in 4Q FY11 - 2Q FY12 (Sustainability } \\
\text { Coordinator - PAIO) } \\
\text { - } \$ 100 \mathrm{~K} \text { per year from 1Q FY12- 4Q FY14 }\end{array}$ \\
\hline
\end{tabular}

\subsubsection{Implementation}

The current schedule for implementation of Goal 3 is shown in Appendix $B$. The timeline includes a list of actions to support accomplishment of the objectives listed above. Appendix B also identifies the estimated resources (beyond those currently available) needed to implement each objective in support of the strategic goal.

The planning team developed initial resource estimates for the actions. These estimates are not complete, so they will continue to be developed and refined as the plan is implemented. The following general guidelines were used:

- Estimates are provided for new efforts or significant workload increases.

- If the teams thought that the action can be accomplished within existing resources, no new requirements are identified.

- If the team thought that the action cannot be completed with existing personnel, a staff hours/ FTE estimate is provided.

- If the team thought that the action would be contracted or purchased, a dollar estimate is provided. 


\subsubsection{Stakeholders}

\begin{tabular}{|ll|}
\hline Fort Leonard Wood Stakeholders & \\
MSCoE STRATCOM Office & $\begin{array}{l}\text { Joint, Interagency, Intergovernmental, } \\
\text { Multinational, Industry, Academia (JIIM-IA) } \\
\text { Capability Development and Integration } \\
\text { Directorate (CDID) }\end{array}$ \\
Public Affairs Office (PAO) & $\begin{array}{l}\text { Secretary of the General Staff (SGS) } \\
\text { DPW Master Plans }\end{array}$ \\
PAIO & $\begin{array}{l}\text { Directorate Plans, Training and Mobilization } \\
\text { (DPTM) }\end{array}$ \\
Medical Command (MEDCOM) & DPW Environmental \\
University of Missouri Liaison & \\
Off-Post Stakeholders & \\
State of Missouri DED & Chamber Director \\
Communities & Meramec Regional Planning Commission \\
Leonard Wood Institute & \\
\hline
\end{tabular}

\subsubsection{Approach}

A FLW sustainability coordinator (in PAIO) would support this activity and coordinate initial participation with community stakeholders. The proponents for specific objectives will provide PAIO with information on scheduled activities, progress in accomplishing activities and meeting targets, and documentation of activities/meetings. As partnerships evolve, especially the regional sustainability partnership, leadership will transition to an external organization that will lead the effort with FLW participating as a regional stakeholder.

\subsubsection{Governance}

The strategic sustainability plan is integrated into Line of Effort 5 of the Senior Commander's Campaign Plan. As such, the goal proponent will be responsible for coordinating activity, providing periodic information as part the performance review of the Senior Commander's Campaign Plan, informing the Garrison Commander of progress, and providing progress data and information for the annual sustainability report (managed by the PAIO). 
Additional needs for integration with other Installation and Garrison functions, standing committees and boards, and external meetings have not been identified at this time. Integration opportunities will be identified and documented as implementation proceeds.

\subsubsection{Reporting}

Progress briefing to the Senior Commander and senior leaders on LOE 5 of the MSCoE campaign plan, which includes ISSP as Objective 5.2, are scheduled are scheduled at the Senior Commander's Executive Sessions.

\subsubsection{Review}

FLW plans to eventually conduct annual reviews. However, in the short term, quarterly meetings will be conducted.

\subsection{Goal 4: Service Members, Families, and Civilians resilient in mind, body, and spirit}

\subsubsection{Description}

Provide Service Members, Families, and Civilians opportunities, programs, and facilities that enable them to become resilient ${ }^{1}$ in mind, body, and spirit. Provide holistic, consolidated, and multi-functional (educational, physical fitness, recreational/leisure, and religious) services. Ensure that all services are based on an ongoing needs assessment.

\subsubsection{Indicators}

- The amount of training and services (or "contact opportunities") for FLW community related to resiliency; roll up into a percentage of population contacted within a year and/ or hours per person of resiliency support

- An aggregate of negative-behavior indicators (e.g., crime statistics, alcoholism, suicide rates, domestic violence).

\subsubsection{Proponent}

Directorate Family Morale, Welfare, and Recreation (DFMWR)

\footnotetext{
${ }^{1}$ Resiliency is defined as the ability to bounce back from difficulty.
} 


\subsubsection{Objectives}

\section{Objectives for Goal 4 are listed in Table 15 - Table 18.}

Table 15. Objective 4.1 - Installation Resiliency Campus.

\section{Objective 4.1: Develop an Installation Resiliency Campus.}

Description: A health and wellness resiliency campus for comprehensive Soldier and family wellness (e.g., Chaplain, ACS, Behavioral Health, ASAP, and Suicide Prevention resources).

\begin{tabular}{|l|l|}
\hline $\begin{array}{l}\text { Lead Organization: DFMWR and the Community Health } \\
\text { Promotion Council }\end{array}$ & Requirements: SR2-2 \\
\hline $\begin{array}{l}\text { Leading Measure(s): } \\
\text { Actions as milestones in development - targets are } \\
\text { completion of actions on schedule }\end{array}$ & $\begin{array}{l}\text { Lagging Measure(s): } \\
\text { Utilization rates of campus activities compared to } \\
\text { pre-campus baseline (increase desired) }\end{array}$ \\
\hline Target(s): See action items in Appendix B & $\begin{array}{l}\text { Target(s): 15\% increase in utilization rates first full } \\
\text { year after opening, then maintain new level annually }\end{array}$ \\
\hline
\end{tabular}

Next Step(s):

- Develop a list of all functions that should be eventually located in the campus - define the desired endstate

- Develop materials to market the Campus and locations of functions

FTEs Required: 60 hours total in 2Q-4Q FY11 and 0.1 FTE in 4Q FY12-13 for support planning; additional FTE to support Campus is TBD

Funding Required: TBD

Table 16. Objective 4.2 - Educational opportunities.

Objective 4.2: Provide access to state-of-the-art, after-hours-accessible classrooms and laboratories to improve all approved degree programs and educational opportunities.

Description: Improve continuing education, civilian degree programs, and all other off-duty training and education through upgrading and/or improved access to state-of-art classrooms and labs. May include facility development through partnerships with educational organizations (schools, universities).

\begin{tabular}{|l|l|}
\hline Lead Organization: DHR-ESO & Requirements: SR4-1 \\
\hline $\begin{array}{l}\text { Leading Measure(s): } \\
\text { Square footage of classrooms available }\end{array}$ & $\begin{array}{l}\text { Lagging Measure(s): } \\
\text { Usage/occupancy rates of available space used for } \\
\text { education }\end{array}$ \\
\hline $\begin{array}{l}\text { Target(s): } \\
\text { - TBD }\end{array}$ & $\begin{array}{c}\text { Target(s): } \\
\text { - TBD }\end{array}$ \\
\hline $\begin{array}{l}\text { Next Step(s): } \\
\text { - Evaluate demand for classroom space and document current allocation process. Identify which facilities } \\
\text { are available at what times. }\end{array}$ \\
- Meet with interested education stakeholders to better understand their needs for expanding education- \\
- Ul opportunities using FLW classrooms \\
$\begin{array}{l}\text { FTE Required: 0.5 FTE in 3Q FY11-1Q FY12 } \\
\text { Funding Required: TBD }\end{array}$ \\
\hline
\end{tabular}


Table 17. Objective 4.3 - Interconnected trail system.

\begin{tabular}{|l|l|}
\hline \multicolumn{2}{|l|}{ Objective 4.3: Construct diverse, interconnected trail system. } \\
$\begin{array}{l}\text { Description: Linked to Mark Twain National Forest and local municipalities. Includes bicycle, pedestrian, and } \\
\text { PARCOURS trails/use with various physical fitness, recreation, and leisure stations. Will also support distance } \\
\text { training for service members. }\end{array}$ \\
\hline $\begin{array}{l}\text { Lead Organization: DFMWR } \\
\begin{array}{l}\text { Leading Measure(s): (Milestones): } \\
\text { - Get funding }\end{array}\end{array} \quad \begin{array}{l}\text { Requirements: } \\
\text { Target(s): TBD once baseline is established }\end{array}$ \\
$\begin{array}{l}\text { Next Step(s): } \\
\text { - Identify any plans local municipalities have with recreational/leisure growth programs. }\end{array}$ \\
\hline $\begin{array}{l}\text { FTE Required: } 40 \text { hours total in 3Q FY11-1Q FY12 + additional FTE is TBD. } \\
\text { Funding Required: TBD }\end{array}$
\end{tabular}

Table 18. Objective 4.4 - Fitness and wellness.

Objective 4.4 Develop, maintain, and sustain facilities and capabilities on the Installation that support Soldier fitness and Family wellness.

Description: Construct indoor physical fitness, recreation, and leisure centers to accommodate growing population. Design and siting considerations should include access/availability of child care services. Includes support to all eligible users (ID card holders - service members, family members, retirees, eligible civilians). Develop and implement a strategy to approve and program additional indoor fitness recreation and leisure center space without being limited by BDE Fitness Centers counting against the Installation's authorized space. May include re-designation of BDE Gyms from Fitness Centers to Multi-use or other type of space since they are used for more than fitness training. Supports IMCOM SR1-3: Develop, maintain, and sustain facilities and capabilities on the installations that support Soldier fitness and a warrior ethos.

\begin{tabular}{|l|l|}
\hline Lead Organization: DFMWR & Requirements: SR1-3 \\
\hline $\begin{array}{l}\text { Leading Measure(s): } \\
\text { Percent of fitness centers compared to R-plan }\end{array}$ & $\begin{array}{l}\text { Lagging Measure(s): } \\
\text { Percentage of fitness centers operating at ISR } \\
\text { Services Green level to support Soldiers and } \\
\text { Families }\end{array}$ \\
\hline $\begin{array}{l}\text { Next Step(s) } \\
\text { - Baseline status of facilities and usage }\end{array}$ & Target(s): 100\% (currently at 100\%) \\
\hline $\begin{array}{l}\text { FTE Required: } 24 \text { hours total in 2Q-3Q FY11 + additional FTE is TBD } \\
\text { Funding Required: \$500k in 1Q FY13 for design charrettes, approximately \$16 million for MCA fitness center } \\
\text { in FY14, and funding for the other activities TBD }\end{array}$
\end{tabular}

\subsubsection{Implementation}

The current schedule for implementation of Goal 4 is shown in Appendix B. The timeline includes a list of actions to support accomplishment of the objectives listed above. Appendix B also identifies the estimated resources 
(beyond those currently available) that will be needed to implement each objective in support of the strategic goal. The planning team developed initial resource estimates for the actions. These estimates are not complete, so they will continue to be developed and refined as the plan is implemented. The following general guidelines were used:

- Estimates are provided for new efforts or significant workload increases.

- If the teams thought that the action can be accomplished within existing resources, no new requirements are identified.

- If the team thought that the action cannot be completed with existing personnel, a staff hours/ FTE estimate is provided.

- If the team thought that the action would be contracted or purchased, a dollar estimate is provided.

\subsubsection{Stakeholders}

\begin{tabular}{ll}
\hline Fort Leonard Wood Stakeholders & \\
Community Health Promotion Council & Public Affairs Office \\
Directorate of Public Works & Family and Morale, Welfare and Recreation \\
Directorate of Human Resources-ESO & MSCoE \\
Medical Command (MEDCOM) & NEC \\
Chaplain &
\end{tabular}

Off-Post Stakeholders

Regional Schools/Universities

\subsubsection{Approach}

The approach for this goal is yet to be determined.

\subsubsection{Governance}

The strategic sustainability plan is integrated into LOE 5 of the Senior Commander's Campaign Plan. As such, the goal proponent will be responsible for coordinating activity, providing periodic information as part the performance review of the Senior Commander's Campaign Plan, informing the Garrison Commander of progress, and providing progress data and information for the annual sustainability report (managed by the PAIO). 
Additional needs for integration with other Installation and Garrison functions, standing committees and boards, and external meetings have not been identified at this time. Integration opportunities will be identified and documented as implementation proceeds.

\subsubsection{Reporting}

Progress briefing to the Senior Commander and the senior leaders on LOE 5 of the MSCoE campaign plan which includes ISSP as Objective 5.2 is scheduled at the Senior Commander's Executive Sessions.

\subsubsection{Review}

FLW plans to eventually conduct annual reviews. However, in the short term, quarterly meetings will be conducted.

\subsection{Goal 5: A culture of pride and trust throughout the Fort Leonard Wood workforce}

\subsubsection{Description}

A sustainable workforce that utilizes employment services and educational opportunities so that it:

- Meets rapidly changing mission requirements

- Has a high level of total fitness and well-being (mental, spiritual, emotional, physical health)

- Is demographically blended (mix of military, retiree, spouses and local and external talent, ages, races, gender)

- Transitions institutional knowledge within the workforce from experienced to new workers

- Has technical knowledge, certification, degrees, ongoing training, licenses

- Is motivated through incentives, rewards, recognition

- Feels they are stakeholders in mission accomplishment

- Has physical facilities and an organizational working environment that support high performance

- Operates within positive people dynamics

- Believes individual and career grouth is institutionally and socially encouraged, rewarded, supported, and balanced with organizational missions and community goals. 


\subsubsection{Indicator}

Components of a sustainable workforce indicator include:

- Retention rate-normalized for deployment and retirement

- Average worker age compared to industry

- Positions filled

- Time to fill open positions

- Coursework military enrollment rates

- Civilian education/ enrollment rates-percentage of staff enrolled in classes.

\subsubsection{Proponent}

\section{Directorate of Human Resources (DHR)}

\subsubsection{Objectives}

Objectives related to Goal 5 are shown in Table 19 - Table 22.

Table 19. Objective 5.1 - Community use of all employment services.

\section{Objective 5.1: Fort Leonard Wood community fully utilizes employment services.}

Description: Workforce organizations work to ensure that the Fort Leonard Wood community is aware of, has access to, and can properly utilize all available employment services, both Federal and local.

Lead Organization:

- DHR

Measure(s):

- Number of applicants/open job compared to expected number (based upon industry standards)

Target(s): All eligible community members seeking employment know of and have access to the Missouri Career Center by 2015
Requirements:

- TBD
Resources Required:

- 0.25 FTE in 3Q FY11-36 and 1.0 FTE in 1Q FY12-36

Funding Required:

- \$50k/yr FY12-27

Next Step(s)

- Baseline usage data 
Table 20. Objective 5.2 - Provide skilled education to workforce.

\begin{tabular}{|c|c|}
\hline \multicolumn{2}{|c|}{$\begin{array}{l}\text { Objective 5.2: Fort Leonard Wood provides opportunities and encouragement for technical knowledge, } \\
\text { certification, degrees, ongoing training, and licenses for the workforce (through posted training events, } \\
\text { partnerships, and tenants, etc.) to build a professional, skilled workforce best positioned to support the mission. }\end{array}$} \\
\hline \multicolumn{2}{|c|}{$\begin{array}{l}\text { Description: Create an environment where the FLW community is motivated to identify, receive, and } \\
\text { document value-added training to insure that training and education needs are identified and appropriate } \\
\text { courses are provided to meet those needs. Training is easily accessible, convenient, and timely. }\end{array}$} \\
\hline $\begin{array}{l}\text { Lead Organization: } \\
\text { - DHR }\end{array}$ & $\begin{array}{l}\text { Requirements: LW1-3, LW2-1, LW4-2, LW5-1, LW5-2, } \\
\text { LW6-1, SF2-1, SF2-2, SF4-1 }\end{array}$ \\
\hline $\begin{array}{l}\text { Leading Measure(s): } \\
\text { - Percent workforce that has completed required } \\
\text { leadership development education for their posi- } \\
\text { tion (as per KTS 3.1.1) }\end{array}$ & $\begin{array}{l}\text { Lagging Measure(s): } \\
\text { - Percentage of staff with IDPs (as per KTS } \\
\text { 3.5.1) } \\
\text { - Workforce satisfaction rating in ACAS (KTS } \\
\text { 3.5.2) } \\
\text { - Percentage of staff meeting IDPs (future) }\end{array}$ \\
\hline Leading Target(s): & $\begin{array}{l}\text { Lagging Target(s): } \\
\text { - Baseline percentage of staff meeting IDPs by } \\
2015 \text { (future) } \\
\text { - All standard new government employees will } \\
\text { have an IDP within } 6 \text { months of starting em- } \\
\text { ployment }\end{array}$ \\
\hline \multicolumn{2}{|l|}{$\begin{array}{l}\text { Next Step(s) } \\
\text { - Document IDP development process } \\
\text { - Describe IDP use }\end{array}$} \\
\hline \multicolumn{2}{|c|}{$\begin{array}{l}\text { Resources Required: } \\
\text { - } 1.0 \text { FTE G37 in 3Q FY11-20 to implement Army Learning Plan (2015-2020) } \\
\text { - } 0.1 \text { FTE DHR, 0.1 FTE CPAC, and 0.1 FTE G37 in 4Q FY11-13 } \\
\text { - } 0.5 \text { FTE CPAC and 0.5 FTE G37 in 1Q FY12-35 } \\
\text { Funding Required: } \\
\text { - } \$ 300 \mathrm{k} / \mathrm{yr} \text { to implement Army Learning Plan (2015-2020) }\end{array}$} \\
\hline
\end{tabular}

Table 21. Objective 5.3 - Workforce sustainability training.

Objective 5.3: Develop a workforce with strong leaders, continuity, and cross-functional support that builds
unstoppable momentum for safe and sustainable use of land, energy (fuel and electricity), and materials.

Description: Integrate sustainability into the culture of the Fort Leonard Wood workforce and leadership. All work should be accomplished with sustainability (as well as safety and occupational health) integrated into all activities and decision-making.

\begin{tabular}{|l|l|}
\hline $\begin{array}{l}\text { Lead Organization: } \\
\text { - DHR }\end{array}$ & $\begin{array}{l}\text { Requirements: IR6-4, EN1-4, EO 13514§2(e)(vi), } \\
\text { EO13514 §2(d)(i) and §2(d)(iii), E013514 §2(e)(i), } \\
\text { §2(e)(viii), and §2(e)(ix), EO13514 §2(j). }\end{array}$ \\
\hline $\begin{array}{l}\text { Measure(s): } \\
\text { - Percent of workforce provided sustainability awareness training } \\
\text { - Number of sustainability events and activities }\end{array}$ \\
$\begin{array}{l}\text { Target(s): } \\
\text { - Training efforts initiated by 4Q 2012, 25\% trained per year through 2015 }\end{array}$
\end{tabular}


Objective 5.3: Develop a workforce with strong leaders, continuity, and cross-functional support that builds unstoppable momentum for safe and sustainable use of land, energy (fuel and electricity), and materials.

Next Step(s):

- Form a sustainability workgroup and forum that people can join to participate in sustainability activities. Provide teachable moments/events on sustainability.

- Coordinate with installation organizations to sponsor events.

Resources Required:

- None, since the DHR Workforce Development Specialist and the PAIO Sustainability Coordinator are accounted for elsewhere in the action plan.

Funding Required:

- $\$ 306 \mathrm{k}$ in FY12

- $\$ 150 k / y r F Y 13-20$

Table 22. Objective 5.4 - Employer of choice.

Objective 5.4: Become an enlightened employer of choice that sustains a workforce that is adaptable, dynamic, collaborative, motivated, and functions sustainably in meeting current and future mission needs.

Description: FLW will meet rapidly changing mission requirements, transition institutional knowledge and address lack of specialized personnel (that will be compounded by future silver tsunami), through the development of a strong workforce through such mechanisms as internships, retention bonuses, internal training, and educational programs/development. FLW enhances its reputation by promoting its outstanding benefits including sustainable workplace options, health care, time for fitness and well-being, and opportunities for advancement as incentives to attract skilled professionals. Mission-accomplishment capabilities are enhanced by developing a workforce with creative ideas.

FLW workforce of supervisors and staff learn and advance in accordance with a staff succession plan as per IMCOM CP LW1-2. Develop and maintain a requirements-driven system of leader development that builds breadth and depth in targeted leader competencies and meets Army and Installation Management needs as per IMCOM CP LW1-1.

\begin{tabular}{|c|c|}
\hline Lead Organization: DHR & Requirements: LW1-1, LW1-2 \\
\hline $\begin{array}{l}\text { Leading Measure(s): } \\
\text { - Percent workforce that has completed required } \\
\text { leadership development education for their posi- } \\
\text { tion (as per KTS 3.1.1) }\end{array}$ & $\begin{array}{l}\text { Lagging Measure(s): } \\
\text { - Combined score of \% of workforce who respond } \\
\text { positively on the Command climate survey for } \\
\text { the following topics: } \\
\text { - Employee climate } \\
\text { - Trust climate } \\
\text { - Empowerment climate }\end{array}$ \\
\hline $\begin{array}{l}\text { Target(s): } \\
\text { - Establish targets for \# of respondents and scores } \\
\text { for the three specified Command climate survey } \\
\text { areas }\end{array}$ & $\begin{array}{l}\text { FTEs Required: } \\
\text { - Approx. } 1.1 \mathrm{FTE} \text { for } 4 \mathrm{Q} \text { FY11-2025 } \\
\text { Funding Required: } \\
\text { - } \$ 225 \mathrm{k} \text { in FY11, } \$ 325 \mathrm{k} \text { in FY12, \$135k in FY13, } \\
\text { \$225k in FY14, \$135k in FY15-36 plus an ad- } \\
\text { ditional \$40k in the years FY15, FY20, FY25, } \\
\text { FY30, and FY35. }\end{array}$ \\
\hline \multicolumn{2}{|c|}{$\begin{array}{l}\text { Next Steps: } \\
\text { - Identify an installation that has a strong workforce development process that has a working succession } \\
\text { plan in place } \\
\text { - Engage with that installation and summarize their lessons learned }\end{array}$} \\
\hline
\end{tabular}




\subsubsection{Implementation}

The current schedule for implementation of Goal 5 is shown in Appendix B. The timeline includes a list of actions to support accomplishment of the objectives listed above. Appendix B also identifies the estimated resources (beyond those currently available) needed to implement each objective in support of the strategic goal. The planning team developed initial resource estimates for the actions. These estimates are not complete, so they will continue to be developed and refined as the plan is implemented. The following general guidelines were used:

- Estimates are provided for new efforts or significant workload increases.

- If the teams thought that the action can be accomplished within existing resources, no new requirements are identified.

- If the team thought that the action cannot be completed with existing personnel, a staff hours/ FTE estimate is provided.

- If the team thought that the action would be contracted or purchased, a dollar estimate is provided.

\subsubsection{Stakeholders}

\begin{tabular}{|ll|}
\hline Fort Leonard Wood Stakeholders & \\
CPAC & Safety Office \\
PAIO & Occupational Health Office \\
Army Career and Alumni Program (ACAP) & DPW \\
MSCoE STRATCOM & DPW - Master Plans \\
MEDCOM & MSCoE G-3/5/7 \\
ACS Employment Readiness Office & \\
Off-Post Stakeholders & \\
Regional Commerce and Growth Association & \\
(RCGA) & \\
\hline
\end{tabular}

\subsubsection{Approach}

A FLW workforce development specialist (hired into DHR) would support this activity in conjunction with CPAC ${ }^{1}$ and G-3/5/7 staff. The DHR lead would work with functional areas and the sustainability lead to identify

\footnotetext{
${ }^{1}$ CPAC: Civilian Personnel Advisory Center.
} 
and obtain or develop sustainability training materials to be integrated into existing training courses. The DHR lead would also conduct training as appropriate and in conjunction with subject matter experts. The DHR lead, CPAC, and G-3/5/ 7 representatives would work together on the succession plan as well as the process for improving the use and accountability of the Individual Development Plan (IDP). DHR, CPAC, and G-3/5/ 7 would also work together to evaluate and where appropriate develop policies with respect to alternate workplace options.

\subsubsection{Governance}

The strategic sustainability plan is integrated with LOE 5 of the Senior Commander's Campaign Plan. As such, the goal proponent will be responsible for coordinating activity, providing periodic information as part the performance review of the Senior Commander's Campaign Plan, informing the Garrison Commander of progress, and providing progress data and information for the annual sustainability report (managed by the PAIO).

Additional needs for integration with other Installation and Garrison functions, standing committees and boards, and external meetings have not been identified at this time. Integration opportunities will be identified and documented as implementation proceeds.

\subsubsection{Reporting}

Progress briefing given to the Senior Commander and the senior leaders on LOE 5 of the MSCoE campaign plan, which includes ISSP as Objective 5.2, are scheduled at the Senior Commander's Executive Sessions.

\subsubsection{Review}

FLW plans to eventually conduct annual reviews. However, in the short term, quarterly meetings will be conducted.

\subsection{Goal 6: Modern, adaptable and high-performance training facilities, ranges, and land}

\subsubsection{Description}

Identify, provide, operate, sustain, and protect the training areas, ranges, and facilities needed to support the current and future missions conducted at FLW. 


\title{
4.6.2 Indicators
}

- Ratio of land needed versus land available for maneuver areas and ranges (acres/ acres).

- Ratio of instructional facilities needed versus available for institutional training (square feet/ square feet) (includes FAC 1711 General Instructional Facilities, FAC 1712 Applied Instructional Facilities).

\subsubsection{Proponent}

\author{
Director of Plans, Training, and Mobilization (DPTM)
}

\subsubsection{Objectives}

\section{Objectives for Goal 6 are shown in Table 23 - Table 26.}

Table 23. Objective 6.1 - Training lands requirements.

Objective 6.1: Accurate, timely, and complete identification of training facilities, ranges, and land requirements.

Description: Improve how training assets requirements are identified, collected, and conveyed to the Garrison from the supported units/organizations. Streamline process for identifying requirements. Training units land and range requirements are input into the Army Range Requirements Model (ARRM) when commandantapproved POIs are sent to TRADOC Training Operations Management Activity (TOMA). Therefore, School Commandants/G3 must ensure that POI developers have identified all training area, land, facility, and road requirements, and that they are correctly annotated in the POls before they are sent to TOMA for validation. There is a constant backlog on POI development. Schools are forced to adjust training based on emerging lessons learned and best practices vs. current POls to ensure training stays current and relevant. This creates a lag in identifying the changes to include increased utilization or new facility requirements training. Requirements for FLW-supported Operational Units and other tenant organizations, as identified in the Army Stationing and Installation Plan, primarily come from Combined Arms Training Strategies (CATS) and Standards in Training Commission (STRAC) guidance. Similar to POIs, CATS, and STRAC generally lag in capturing Commander's training requirements. A streamlined process needs to link G3 to CATS and STRAC proponents, as well as force design and modernization activities to be able to adequately forecast requirement changes. Process must include tracking of changes while under development through approval, capturing the MSCoE Sustainable Range Program doctrinal analysis, then verification of requirements in the ARRM.

Lead Organization: G3

Requirements:

- TBD

Measure(s):

- Percentage of courses in ATRRS that will train on FLW that were evaluated in the doctrinal analysis

- Percentage of units in ASIP that will train on FLW that were evaluated in the doctrinal analysis

- Number of range training days not executable due to requirements not being identified in the doctrinal analysis

- Number of $\mathrm{Km} 2$ days not executable due to requirements not being identified in the doctrinal analysis

- Percentage of Commandant-approved POls that have range or training land requirement errors

- Percentage of POls that are current (less than 2 years old)

Target(s):

- TBD based upon baselines 
Objective 6.1: Accurate, timely, and complete identification of training facilities, ranges, and land requirements.

Next Step(s):

- Develop and maintain a list of the courses delivered (by school) through 2016 to include estimated throughput

- Develop list that documents institutional, operational, and Reserve Component training activities

- Continue developing a policy and procedure that ensures staffing of requirement documents through G3 and MSCoE resource managers before approval and submission to TRADOC

FTE Required:

- 0.9 FTE in FY11

- $1.1 \mathrm{FTE}$ in FY12

- 1.0 FTE in FY13-36

Funding Required: $\$ 0$

Table 24. Objective 6.2 - Facility and land acquisition conservation strategies.

Objective 6.2: Develop plan and implement an acquisition strategy to provide modern, adaptable, sustainable, and high-performance training facilities on FLW for all training requirements.

Description: Develop sufficient capabilities so that units can accomplish all required training on FLW in accordance with the doctrinal analysis. Develop multi-purpose ranges and facilities as much as possible. May be implemented through various funding and management methods (i.e., Range Development Plan (RDP), Range Complex Master Plan (RCMP)). Includes taking advantage of existing/available mission encroachment planning tools to help optimize the location and development of new ranges/training areas and eliminate or reduce any potential limitations/constraints.

Lead Organization: DPTMS/DPW Master Planner

Requirements:

- TBD

Measure(s):

- Number of range training days captured in doctrinal analysis that are not executable due to not being addressed in the RDP/RDMP

- Number of $\mathrm{Km} 2$ days captured in doctrinal analysis that are not executable due to not being addressed in the RDP/RDMP

- Percentage of range training days by tope deficit or not fulfilled by alternate means IAW RCMP

- Percentage of $\mathrm{Km} 2$ days maneuver land by type deficit or not fulfilled by alternate means IAW RCMP

Target(s):

- Determine after baseline is developed

Next Step(s):

- Define desired buffers for training land (during Master Plan update?)

- Determine current land and status (owned by Army, USFS or private interest) serving as buffer

- Explore buffer development tools like conservation easements

FTEs Required:

- 0.5 FTE in 3Q FY11-13

Funding Required:

- \$250K in 3Q FY11 
Table 25. Objective 6.3 - Training lands and facilities for missions.

\begin{tabular}{|c|c|}
\hline \multicolumn{2}{|c|}{$\begin{array}{l}\text { Objective 6.3: Operate, modernize, and sustain training land, ranges, and facilities to meet mission } \\
\text { requirements. (SR4-2) }\end{array}$} \\
\hline \multicolumn{2}{|c|}{$\begin{array}{l}\text { Description: Operate includes receiving requests, scheduling, prioritizing, and operational support. } \\
\text { Sustainment includes SRM and target maintenance. Implement includes updated technology, equipment, } \\
\text { targetry, and support facilities to modernize ranges and enhance capabilities. Ties into DPTM Range } \\
\text { Development Plan and Integrated Training Area Management program. Supports SR1-4: Develop more } \\
\text { effective and efficient practices to deliver training support to units throughout the ARFORGEN cycles; and } \\
\text { SR3-1: Utilize and adapt existing training capabilities and facilities to a transformed Army. }\end{array}$} \\
\hline Lead Organization: DPTM & Requirements: SR1-4, SR3-1, and SR4-2 \\
\hline $\begin{array}{l}\text { Leading Measure(s): } \\
\text { - Percentage of SCINI requirements supported by } \\
\text { projects in WAM (approximately 70\% FY2008- } \\
\text { 2011) }\end{array}$ & $\begin{array}{l}\text { Lagging Measure(s): } \\
\text { - Percentage of training requirements (unit and } \\
\text { institutional, excludes MTT instruction) met by } \\
\text { FLW facilities }\end{array}$ \\
\hline \multicolumn{2}{|l|}{ Target(s): Determine using current baselines } \\
\hline \multicolumn{2}{|c|}{$\begin{array}{l}\text { Next Step(s) } \\
\text { - Continue to improve communication among DPTM, G37, S3's, and end users to develop better under- } \\
\text { standing of capabilities and limitations (manage expectations). }\end{array}$} \\
\hline $\begin{array}{l}\text { FTE Required: } 0.5 \text { FTE in 3Q FY11-2025 } \\
\text { Funding Required: TBD (project specific) }\end{array}$ & \\
\hline
\end{tabular}

Table 26. Objective 6.4 - Protect training lands.

Objective 6.4. Protect and preserve training lands for current and future missions.

Description: Use all available and emerging tools/mechanisms/programs and partnerships to buffer and protect training areas from internal and external encroachment. Effective regional sustainable land-use management will also enhance the ability to have watershed and ecosystem-based programs in partnerships between FLW and the surrounding communities to protect drinking water supplies, manage stormwater, manage critical habitats, and provide expanded recreational opportunities.

\begin{tabular}{|c|c|}
\hline Lead Organization: DPW & $\begin{array}{l}\text { Requirements: } \\
\text { - TBD }\end{array}$ \\
\hline $\begin{array}{l}\text { Leading Measure(s): } \\
\text { - Percentage of training areas protected from en- } \\
\text { croachment (external) } \\
\text { - Percentage of mission-scape requirements sup- } \\
\text { ported by projects in WAM }\end{array}$ & $\begin{array}{l}\text { Lagging Measure(s): } \\
\text { - Square feet of facilities that are incompatible } \\
\text { zoning areas } \\
\text { - Percent of buffer in place }\end{array}$ \\
\hline Target(s): TBD & Target(s): TBD \\
\hline \multicolumn{2}{|c|}{$\begin{array}{l}\text { Next Step(s): } \\
\text { - Develop and installation-wide real property master plan that defines compatible development zones for } \\
\text { all areas within FLW }\end{array}$} \\
\hline \multicolumn{2}{|l|}{ FTE Required: 0.5 FTE in 3Q FY11-13 } \\
\hline
\end{tabular}




\subsubsection{Implementation}

The current schedule for implementation of Goal 6 is shown in Appendix $B$. The timeline includes a list of actions to support accomplishment of the objectives listed above. Appendix B also identifies the estimated resources (beyond those currently available) needed to implement each objective in support of the strategic goal.

The planning team developed initial resource estimates for the actions. These estimates are not complete, so they will continue to be developed and refined as the plan is implemented. The following general guidelines were used.

- Estimates are provided for new efforts or significant workload increases.

- If the teams thought that the action can be accomplished within existing resources, no new requirements are identified.

- If the team thought that the action cannot be completed with existing personnel, a staff hours/ FTE estimate is provided.

- If the team thought that the action would be contracted or purchased, a dollar estimate is provided.

\subsubsection{Stakeholders}

\section{Fort Leonard Wood Stakeholders}

MSCoE G3 MSCoE G37

DPTM DPW

DPW Master Planner DPW Real Property

DPTM Range Master Planner DPW Environmental

DPTM Range Planner DPTM Range Division

Off-Post Stakeholders

IMCOM HQ and NE Region

Surrounding communities

\subsubsection{Approach}

Ongoing identification of training requirements is correctly input into the POIs, generating accurate range requirements. Coordinate with G37 to ensure the updated POIs are set to Training Operations Management Activity (TOMA) and uploaded into Army Range Requirements Model (ARRM). Updated ARRM requirements are imported into the Range Complex Mas- 
ter Plan (RCMP) tool to support land acquisition. Specific projects to be developed from acquisition strategy, based on requirements.

\subsubsection{Governance}

The strategic sustainability plan is integrated into LOE 5 of the Senior Commander's Campaign Plan. As such, the goal proponent will be responsible for coordinating activity, providing periodic information as part the performance review of the Senior Commander's Campaign Plan, informing the Garrison Commander of progress, and providing progress data and information for the annual sustainability report (managed by the PAIO).

Additional needs for integration with other Installation and Garrison functions, standing committees and boards, and external meetings has not been identified at this time. Integration opportunities will be identified and documented as implementation proceeds.

\subsubsection{Reporting}

Progress briefings to the Senior Commander and the senior leaders on LOE 5 of the MSCoE campaign plan, which includes ISSP as Objective 5.2 are scheduled at the Senior Commander's Executive Sessions.

\subsubsection{Review}

FLW plans to eventually conduct annual reviews. However, in the short term, quarterly meetings will be conducted. 


\section{Glossary}

\begin{tabular}{|c|c|c|}
\hline Term & Definition & Reference \\
\hline Action & $\begin{array}{l}\text { Organized activity (specific tasks or steps) to accomplish } \\
\text { an objective. }\end{array}$ & \\
\hline Action Plans & $\begin{array}{l}\text { Documents that describe the specific method or process } \\
\text { for achieving the results called for by one or more } \\
\text { objectives of the strategic plan. }\end{array}$ & Army Regulation 5-1 \\
\hline $\begin{array}{l}\text { Army's Triple } \\
\text { Bottom Line-Plus } \\
(\mathrm{TBL}+)\end{array}$ & $\begin{array}{l}\text { Mission, Community, Environment, and Economic Benefits. } \\
\text { A shorthand tool to assist with integration of sustainability } \\
\text { in planning and decision making. }\end{array}$ & \\
\hline $\begin{array}{l}\text { Challenge } \\
\text { Statement }\end{array}$ & $\begin{array}{l}\text { A brief statement that assimilates multiple issues of } \\
\text { concern for a given planning team or core business area } \\
\text { and is intended to focus subsequent planning steps on the } \\
\text { key (or most significant) issues. }\end{array}$ & Challenge Statement \\
\hline Goal & $\begin{array}{l}\text { A specific end toward which resources and effort are } \\
\text { expended. }\end{array}$ & Army Regulation 5-1 \\
\hline Governance & $\begin{array}{l}\text { The system of management and controls exercised in the } \\
\text { stewardship of an organization. }\end{array}$ & $\begin{array}{l}\text { Baldrige National } \\
\text { Quality Program 2009- } \\
2010 \text { Criteria for } \\
\text { Performance Excellence }\end{array}$ \\
\hline Indicators & See "Measure" & \\
\hline $\begin{array}{l}\text { Integrated Strategic } \\
\text { And Sustainability } \\
\text { Planning (ISSP) }\end{array}$ & $\begin{array}{l}\text { The primary goal of the ongoing ISSP process is the } \\
\text { expansion of garrison planning to include the principles of } \\
\text { sustainability. When garrison planning is already mature, } \\
\text { ISSP serves to enhance integration of the principles of } \\
\text { sustainability with other planning efforts and to encourage } \\
\text { innovation. When garrison planning is less mature, the } \\
\text { ISSP helps planners through a process (backcasting) that } \\
\text { results in an initial long- and short-range plan while } \\
\text { providing training and tools necessary for measurable } \\
\text { progress and continual improvement. }\end{array}$ & $\begin{array}{l}\text { IMCOM HQ OPORD 11- } \\
480 \text { and IMCOM Policy } \\
\text { Memorandum 11-32-1 }\end{array}$ \\
\hline Measure & $\begin{array}{l}\text { How progress for a particular Objective will be assessed; a } \\
\text { fact or statistic reflecting a particular aspect of } \\
\text { performance. }\end{array}$ & \\
\hline Objective & $\begin{array}{l}\text { Specific, measurable, achievable, relevant, and time- } \\
\text { sensitive, an objective is an intermediate end-state that } \\
\text { accomplishes one or more of the goals in part or in whole. }\end{array}$ & \\
\hline $\begin{array}{l}\text { Principles of } \\
\text { Sustainability }\end{array}$ & $\begin{array}{l}\text { Mission Excellence, Community Collaboration, } \\
\text { Environmental Stewardship, Economic Impact, and } \\
\text { Systems Thinking }\end{array}$ & $\begin{array}{l}\text { IMCOM HQ OPORD 11- } \\
480 \text { and IMCOM Policy } \\
\text { Memorandum 11-32-1 }\end{array}$ \\
\hline Stakeholders & $\begin{array}{l}\text { All groups that might be affected by an organization's } \\
\text { actions and success. Examples of key stakeholders } \\
\text { include leaders, customers, employees, partners, and local } \\
\text { or professional communities. }\end{array}$ & Army Regulation 5-1 \\
\hline
\end{tabular}




\begin{tabular}{|c|c|c|}
\hline Term & Definition & Reference \\
\hline $\begin{array}{l}\text { Strategic } \\
\text { Challenges }\end{array}$ & $\begin{array}{l}\text { Pressures that exert a decisive influence on an } \\
\text { organization's likelihood of future success. }\end{array}$ & $\begin{array}{l}\text { Baldrige National } \\
\text { Quality Program 2009- } \\
2010 \text { Criteria for } \\
\text { Performance Excellence }\end{array}$ \\
\hline Strategic Plan & $\begin{array}{l}\text { The document produced by the process in which an } \\
\text { organization envisions its future and develops special } \\
\text { management strategies and action or implementation } \\
\text { plans to achieve that future. }\end{array}$ & Army Regulation 5-1 \\
\hline Strategic Planning & $\begin{array}{l}\text { The process by which managers at higher levels envision } \\
\text { their organization's future and develop the necessary } \\
\text { procedures and operations to achieve that vision. It is a } \\
\text { continuous and systematic effort to determine and meet } \\
\text { the future needs of customers. }\end{array}$ & Army Regulation 5-1 \\
\hline \multirow[t]{4}{*}{ Sustainability } & $\begin{array}{l}\text { Managing resources so they are available when needed to } \\
\text { accomplish the mission. Resources include: Human } \\
\text { Capital (including knowledge), Natural Resources, } \\
\text { Infrastructure (fixed and mobile), Information Technology, } \\
\text { Financial, and Energy. }\end{array}$ & $\begin{array}{l}\text { IMCOM HQ OPORD 11- } \\
480 \text { and IMCOM Policy } \\
\text { Memorandum 11-32-1 }\end{array}$ \\
\hline & $\begin{array}{l}\text { Meeting current as well as future mission requirements } \\
\text { worldwide while safeguarding human health, improving } \\
\text { quality of life, and enhancing our natural environment. }\end{array}$ & $\begin{array}{l}\text { Army Sustainability } \\
\text { Campaign Plan (Draft) }\end{array}$ \\
\hline & $\begin{array}{l}\text { To create and maintain conditions, under which humans } \\
\text { and nature can exist in productive harmony, that permit } \\
\text { fulfilling the social, economic, and other requirements of } \\
\text { present and future generations. }\end{array}$ & Executive Order 13514 \\
\hline & $\begin{array}{l}\text { An organization's ability to address current business needs } \\
\text { and to have the agility and strategic management to } \\
\text { prepare successfully for the future business, market, and } \\
\text { operating environments. }\end{array}$ & $\begin{array}{l}\text { Baldrige National } \\
\text { Quality Program 2009- } \\
2010 \text { Criteria for } \\
\text { Performance Excellence }\end{array}$ \\
\hline Target & $\begin{array}{l}\text { A single-year intermediate end-state to measure progress } \\
\text { toward an objective in terms of the applicable measures. }\end{array}$ & \\
\hline
\end{tabular}




\section{Abbreviations}

\begin{tabular}{|c|c|}
\hline Term & Meaning \\
\hline AAFES & Army, Air Force Exchange Service \\
\hline AC & air conditioning \\
\hline ACAP & Army Career and Alumni Program \\
\hline ACS & Army Community Services \\
\hline ACUB & Army Compatible Use Buffer Program \\
\hline $\mathrm{AF}$ & appropriated funds \\
\hline AFORGEN & Army Force Generation \\
\hline AMC & Army Materiel Command, US Army \\
\hline AP & airport \\
\hline APA & aircraft parking area \\
\hline ARFORGEN & Army Force Generation Process \\
\hline ARL & Army Research Laboratory \\
\hline ARRM & Army Range Requirements Model \\
\hline ASAP & Army Substance Abuse Program \\
\hline ASST & assistance \\
\hline $\mathrm{BDE}$ & Brigade \\
\hline BEM & Best Energy Management \\
\hline BRAC & Base Realignment And Closure \\
\hline C\&D & construction and demolition \\
\hline CAC & Common Access Card or Combined Arms Center \\
\hline CATS & Combined Arms Training Strategies \\
\hline CBRN & chemical, biological, radiological, and nuclear \\
\hline CDID & Capability Development and Integration Directorate \\
\hline CERL & Construction Engineering Research Laboratory \\
\hline CES & Civilian Education System \\
\hline CLS & common level of services \\
\hline CPAC & Civilian Personnel Advisory Center \\
\hline CRADA & Cooperative Research and Development Agreement \\
\hline $\mathrm{CY}$ & calendar year \\
\hline $\mathrm{DA}$ & Department of the Army \\
\hline DED & Department of Economic Development \\
\hline DEERS & Defense Enrollment Eligibility Reporting System \\
\hline DEP & deployment \\
\hline DFAC & dining facility \\
\hline DFMWR & Directorate of Family and Morale, Welfare, and Recreation \\
\hline
\end{tabular}




\begin{tabular}{|c|c|}
\hline Term & Meaning \\
\hline DHR & Directorate of Human Resources \\
\hline DHR-ESO & Directorate of Human Resources - Education Services Office \\
\hline DOD & Department of Defense \\
\hline DOJ & Department of Justice \\
\hline DOL & Directorate of Logistics \\
\hline DOM & Directorate of Maintenance \\
\hline DOS & Department of State \\
\hline DOSS & Directorate of Support Services \\
\hline DPTM & Directorate of Plans, Training, and Mobilization \\
\hline DPW & Directorate of Public Works \\
\hline DPW ED & DPW Engineering Division \\
\hline DPW Env & DPW Environmental \\
\hline DPW MP & DPW Master Planning \\
\hline DPW Ops & DPW Operations \\
\hline DRM & Directorate of Resource Management \\
\hline DUSDA-I\&E & Deputy Under Secretary of Defense - Installations and Environment \\
\hline ED & Economic Development \\
\hline EISA & Energy Independence and Security Act \\
\hline EN & Energy Efficiency and Security (IMCOM Campaign Plan LOE 6) \\
\hline EO & Equal Opportunity (employment); also, Executive Order \\
\hline EPA & US Environmental Protection Agency \\
\hline EPAct & Energy Policy Act \\
\hline ERDC & Engineer Research and Development Center \\
\hline ESCO & Energy Service Company \\
\hline $\mathrm{ESOH}$ & Environment, Safety and Occupational Health \\
\hline ESPC & Energy Savings Performance Contract \\
\hline FAA & Federal Aviation Administration \\
\hline FAC & facility analysis category \\
\hline FAQ & frequently asked question \\
\hline $\mathrm{FCl}$ & Facility Condition Index \\
\hline FLO & Family Liaison Office (Department of State) \\
\hline FMWR & Family and Morale, Welfare and Recreation \\
\hline FORSCOM & Forces Command \\
\hline FTE & full-time equivalent \\
\hline $\mathrm{FY}$ & fiscal year \\
\hline GC & Garrison Commander \\
\hline G1 & Deputy Chief of Staff for Personnel (General Officer level organization) \\
\hline G3 & Deputy Chief of Staff for Operations (General Officer level organization) \\
\hline G-3/5/7 & Army Staff designation for Operations, Plans, and Policy \\
\hline
\end{tabular}




\begin{tabular}{|c|c|}
\hline Term & Meaning \\
\hline G37 & Deputy Chief of Staff for Operations and Training \\
\hline G6 & Deputy Chief of Staff for Information \\
\hline GS-13 & General Schedule Pay Grade 13 \\
\hline GSA & General Services Administration \\
\hline HAZMAT & hazardous material \\
\hline HVAC & heating, ventilating, and air conditioning \\
\hline IAW & in accordance with \\
\hline ICE & Interactive Customer Evaluation \\
\hline ID & identification \\
\hline IDG & Installation Design Guide \\
\hline IDP & Individual Development Plan \\
\hline IED & improvised explosive device \\
\hline IEDD & Improvised Explosive Device Defeat \\
\hline IMCOM & U.S. Army Installation Management Command \\
\hline IMCOM CP & U.S. Army Installation Management Command Campaign Plan \\
\hline IMCP & Installation Management Campaign Plan \\
\hline IR & Installation Readiness (from IMCOM Campaign Plan LOE 4) \\
\hline ISO & International Organization for Standardization \\
\hline ISR & Installation Status Report \\
\hline ISR-I & Installation Status Report - Infrastructure \\
\hline ISR-NI & Installation Status Report -Natural Infrastructure \\
\hline ISR-S & Installation Status Report - Services \\
\hline ISSP & Integrated Strategic Sustainability Plan \\
\hline ISV & initial site visit \\
\hline ITRO & Interservice Training Review Organization \\
\hline JIIM-IA & $\begin{array}{l}\text { Joint, Interagency, Intergovernmental, and Multinational - Industry, } \\
\text { Academia }\end{array}$ \\
\hline JLUS & Joint Land Use Study \\
\hline LEED & Leadership in Energy and Environmental Design \\
\hline LGFS & Local Government Finance System \\
\hline LOE & Line of Effort \\
\hline LTD & long-term delay \\
\hline LW & Leader and Workforce Development (from IMCOM Campaign Plan, LOE 3) \\
\hline LWI & Leonard Wood Institute \\
\hline MCA & Military Construction, Army \\
\hline MEB & Maneuver Enhancement Brigade \\
\hline MEDCOM & US Army Medical Command \\
\hline MILCON & Military Construction \\
\hline MO & Missouri \\
\hline
\end{tabular}




\begin{tabular}{|c|c|}
\hline Term & Meaning \\
\hline MOA & memorandum of agreement \\
\hline MOB & mobilization \\
\hline MOU & memorandum of understanding \\
\hline MP & Master Plan; Military Police \\
\hline MRPC & Meramec Regional Planning Commission \\
\hline MSCoE & Maneuver Support Center of Excellence \\
\hline MTT & Mobile Training Teams \\
\hline MWR & morale, welfare, and recreation \\
\hline N/A & not applicable \\
\hline NAF & non-appropriated funds \\
\hline NATO & North Atlantic Treaty Organization \\
\hline $\mathrm{NCO}$ & Non-Commissioned Officer \\
\hline NE & northeast \\
\hline NEC & Network Enterprise Center \\
\hline NOV & Notice of Violation \\
\hline O\&M & operation and maintenance \\
\hline OASS & One Army School System \\
\hline Obj & objective \\
\hline OEA & Office of Economic Adjustment \\
\hline OMA & Operations and Maintenance, Army \\
\hline OPA & Other Procurement, Army \\
\hline OPM & Office of Personnel Management \\
\hline OPTEMPO & operational tempo \\
\hline OTC & Ozark Technical Community College \\
\hline P2 & pollution prevention \\
\hline PAIO & Plans, Analysis, and Integration Office \\
\hline PAO & Public Affairs Office \\
\hline PARCOURS & $\begin{array}{l}\text { A fitness trail consisting of a path or course equipped with obstacles or } \\
\text { stations distributed along its length }\end{array}$ \\
\hline PCGA & Pulaski County Growth Alliance \\
\hline PCS & Permanent Change of Station \\
\hline POC & point of contact \\
\hline POI & Program of Instruction \\
\hline POM & Program Objective Memorandum \\
\hline PR & public relations \\
\hline $\mathrm{Q}$ & quarter (i.e., quarter of a fiscal year) \\
\hline $\mathrm{QA}$ & quality assurance \\
\hline QAE & quality assurance elements \\
\hline QOL & quality of life \\
\hline
\end{tabular}




\begin{tabular}{|c|c|}
\hline Term & Meaning \\
\hline$R \& D$ & research and development \\
\hline RCGA & Regional Commerce and Growth Association \\
\hline $\mathrm{RCl}$ & Residential Communities Initiative \\
\hline RCMP & Range Complex Master Plan \\
\hline RDP & Range Development Plan \\
\hline RIF & reduction in force \\
\hline RM & resource management \\
\hline ROI & return on investment \\
\hline $\mathrm{RPC}$ & Regional Planning Commission \\
\hline RPMP & Real Property Master Plan \\
\hline S\&T & science and technology \\
\hline S3 & Brigade or Battalion Operations and Training Officer \\
\hline SASC & Senate Armed Services Committee \\
\hline SATB & Semiannual Training Briefing \\
\hline SC & Senior Commander \\
\hline SCINI & Senior Commander's Installation Needs and Issues \\
\hline SF & safety (from IMCOM Campaign Plan LOE 5) \\
\hline SGS & Secretary to the General Staff \\
\hline SME & subject matter expert \\
\hline SOP & standing operating procedure \\
\hline SR & IMCOM Campaign Plan LOE 1: Soldier, Family and Civilian Readiness \\
\hline SRM & sustainment, restoration, and modernization \\
\hline SRP & Soldier Readiness Processing \\
\hline STEP/SCEP & $\begin{array}{l}\text { Student Temporary Employment Program / Student Career Experience } \\
\text { Program }\end{array}$ \\
\hline STRAC & Standards in Training Commission \\
\hline STRATCOM & Strategic Communications \\
\hline Sust & sustainability \\
\hline SW & Soldier, Family and Civilian Well-being (from IMCOM Campaign Plan LOE 2) \\
\hline SWOT & strengths, weaknesses, opportunities, and threats \\
\hline TA & training area \\
\hline TAPES & Total Army Performance Evaluation System \\
\hline TBD & to be determined \\
\hline TDY & temporary duty \\
\hline TNG & training \\
\hline TOMA & Training Operations Management Activity \\
\hline TRADOC & US Army Training and Doctrine Command \\
\hline TRAP & Training Resource Arbitration Panel \\
\hline TSSE & training support systems and equipment \\
\hline
\end{tabular}




\begin{tabular}{|l|l|}
\hline Term & Meaning \\
\hline ULEV & ultra-low emissions vehicles \\
\hline UM & University of Missouri \\
\hline UMCS & Utility Management Control System \\
\hline USACE & US Army Corps of Engineers \\
\hline VA & Veterans Administration \\
\hline WAM & work plan analysis model \\
\hline WMD-CST & Weapons of Mass Destruction Civil Support Teams \\
\hline WTU & Warrior Transition Unit \\
\hline
\end{tabular}




\section{Appendix A: SWOT Analyses}

The six FLW Core Business Areas were subdivided into major activities purposes of a more detailed SWOT analyses. These are listed below.

1. Caring for Soldiers and Families

o Physical fitness and recreation

o Support programs, services, and training

o Spiritual and relational support

2. Community Engagement

o Support economic development

o Communication

o Stakeholder engagement

o Marketing FLW to regional and national partners

3. Infrastructure

o Design/build

o Operate/renovate/ recycle

4. Mission Services

o Force protection/safety

o Maintenance

- DOL/DOSS/ DOM Transportation

5. Training

o Plan

o Resources

o Execute

o Assess

6. Workforce

o Training and Development (EO)

o Management

o Information/Communication

o Benefits

Reproductions of actual SWOT matrices are given as Figure 6- Figure 25. 
Caring for Soldiers/Families: Physical Fitness/Recreation

\begin{tabular}{|c|c|c|c|c|}
\hline & Mission & Community & Environment & Cost \\
\hline 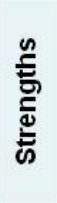 & $\begin{array}{l}\text { - Hi-profile physical } \\
\text { fitness. } \\
\text {-Variety of services } \\
\text {-Comprehensive } \\
\text {-Quality } \\
\text { - Communication }\end{array}$ & $\begin{array}{l}\text { - Local partnerships } \\
\text { - Growing population } \\
\text { - Location } \\
\text { - Strong Congressional } \\
\text { support }\end{array}$ & $\begin{array}{l}\text { - Climate } \\
\text { - Natural resources }\end{array}$ & $\begin{array}{l}\text { - Minimal cost to } \\
\text { participants }\end{array}$ \\
\hline 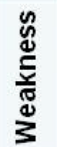 & $\begin{array}{l}\text { - Need for additional } \\
\text { physical fitness space }\end{array}$ & & $\begin{array}{l}\text { - Lack of physical } \\
\text { space (green space) } \\
\text { - Lack of parking } \\
\text { - Bicycle trail (Polla Rd) }\end{array}$ & $\begin{array}{l}\text { - Unfunded } \\
\text { - Funding } \\
\text { restrictions }\end{array}$ \\
\hline 总 & $\begin{array}{l}\text { - Aging infrastructure } \\
\text { - Deployments } \\
\text { - OPTEMPO }\end{array}$ & $\begin{array}{l}\text { - Local competition } \\
\text { - Remote location } \\
\text { - Expandingpopulation } \\
\text { - Public perception } \\
\text { - Lack of outside (community) } \\
\text { private/public physical fitness } \\
\text { opportunities }\end{array}$ & $\begin{array}{l}\text { - Political change } \\
\text { - Public perception } \\
\text { - Economy }\end{array}$ & $\begin{array}{l}\text { - Funding } \\
\text { uncertainty } \\
\text { - Hi-cost } \\
\text { maintenance }\end{array}$ \\
\hline 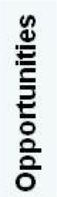 & $\begin{array}{l}\text { - Family oriented } \\
\text { programs } \\
\text { - Comprehensive } \\
\text { soldier fitness }\end{array}$ & $\begin{array}{l}\text { - Expandingpopulation } \\
\text { - Remote uniqueness } \\
\text { - Location } \\
\text { - FLWlocal focal point } \\
\text { - Census }\end{array}$ & - Natural resources & $\begin{array}{l}\text { - Increase local } \\
\text { recreational } \\
\text { partnerships } \\
\text {-Army Family } \\
\text { Covenant funds } \\
\text { - Recycling funds }\end{array}$ \\
\hline
\end{tabular}

Figure 6. SWOT analysis for Physical Fitness/Recreation.

\begin{tabular}{|c|c|c|c|c|}
\hline 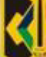 & \multicolumn{4}{|c|}{ Caring for Soldiers/Families: Support Services } \\
\hline & Mission & Community & Environment & Cost \\
\hline 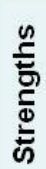 & $\begin{array}{l}\text {-Quality of services } \\
\text { - Communication } \\
\text { - Local university } \\
\text { partnership }\end{array}$ & $\begin{array}{l}\text {-Partnership - industry, } \\
\text { academia } \\
\text { - Strong Congressional } \\
\text { support }\end{array}$ & - Recycling center & -Army Covenant \\
\hline 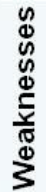 & $\begin{array}{l}\text {-Access to specialty } \\
\text { care } \\
\text { - Lack of physical } \\
\text { fitness space } \\
\text { - Lack of parking }\end{array}$ & - Employee turnover & $\begin{array}{l}\text { - Lack of physical } \\
\text { space }\end{array}$ & $\begin{array}{l}\text { - Contract } \\
\text { providers }\end{array}$ \\
\hline 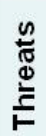 & $\begin{array}{l}\text { - Aging infrastructure } \\
\text {-OP tempo } \\
\text { - Deployments }\end{array}$ & $\begin{array}{l}\text { - Growth } \\
\text { - Public perception }\end{array}$ & -Weather & $\begin{array}{l}\text { - Economy } \\
\text { - Funding } \\
\text { uncertainty }\end{array}$ \\
\hline 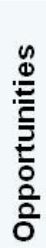 & $\begin{array}{l}\text { - Consolidation of } \\
\text { support services }\end{array}$ & $\begin{array}{l}\text { - Growth } \\
\text { - Census } 2010 \\
\text { - FLW a focal point in SC } \\
\text { MO }\end{array}$ & -Natural resources & $\begin{array}{l}\text { - Increase local } \\
\text { recreational } \\
\text { partnerships }\end{array}$ \\
\hline
\end{tabular}

Figure 7. SWOT analysis for Support Services. 


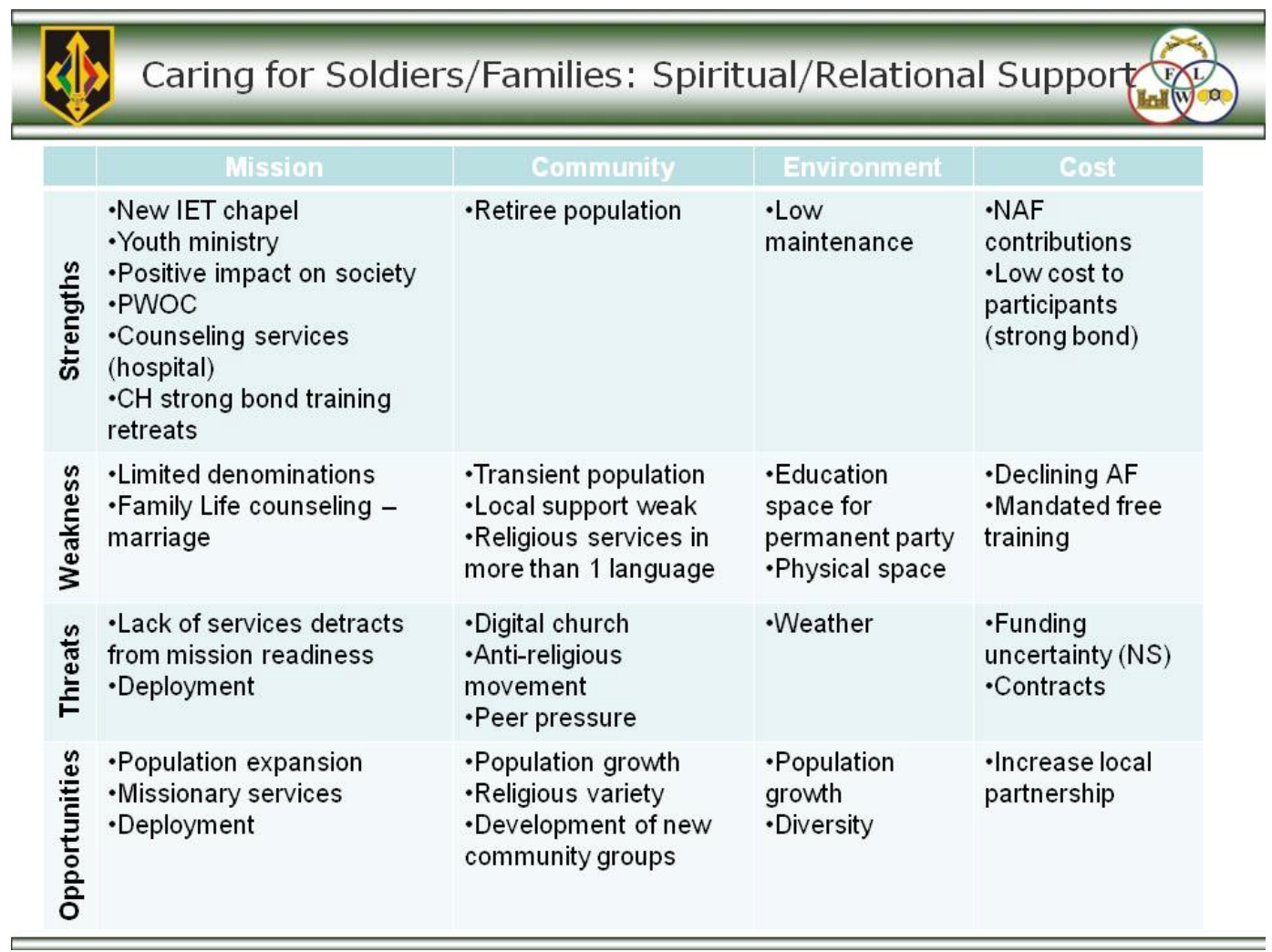

Figure 8. SWOT analysis for Spiritual/Relational Support.

\begin{tabular}{|c|c|c|c|c|}
\hline & Mission & Community & Environment & Cost \\
\hline 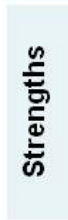 & $\begin{array}{l}\text {-Provide opportunity } \\
\text {-Provide job fairs }\end{array}$ & $\begin{array}{l}\text {-Encouragement of } \\
\text { development } \\
\text { - Local contracting } \\
\text { - Missouri Job Service is } \\
\text { available } \\
\text { - Highly trained workforce }\end{array}$ & $\begin{array}{l}\text { - Contract } \\
\text { recycling }\end{array}$ & \\
\hline 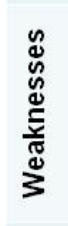 & $\begin{array}{l}\text {-Fairness between } \\
\text { cities } \\
\text {-Friendship can be a } \\
\text { negative for } \\
\text { development } \\
\text {-No promises }\end{array}$ & $\begin{array}{l}\text {-The only game in town for } \\
\text { employees }\end{array}$ & $\begin{array}{l}\text { - Topographic } \\
\text { challenges - } \\
\text { no flat areas } \\
\text { to build }\end{array}$ & \\
\hline 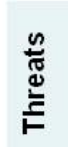 & - Closure of FLW & $\begin{array}{l}\text {-Multi-community interest } \\
\text { - Lack technology }\end{array}$ & $\begin{array}{l}\text { Regulation } \\
\text { changes in } \\
\text { laws/policies }\end{array}$ & - Lack of funding \\
\hline 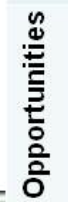 & $\begin{array}{l}\text {-Additional missions } \\
\cdot R \& D \\
\cdot \text {-More direct funding }\end{array}$ & $\begin{array}{l}\text { - Growth to bring in other } \\
\text { business/industrial } \\
\text {-Plenty of land }\end{array}$ & $\begin{array}{l}\text {-Undeveloped } \\
\text { land }\end{array}$ & $\begin{array}{l}\text { - Direct funding } \\
\text { - More military retirees } \\
\text { - Cost of living } \\
\text { - Many contractors }\end{array}$ \\
\hline
\end{tabular}

Figure 9. SWOT analysis for Economic Development. 


\begin{tabular}{|c|c|c|c|c|}
\hline & Mission & Community & Environment & Cost \\
\hline 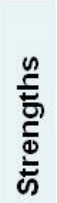 & $\begin{array}{l}\text { - Dedicated org outlets } \\
\text { - Trained professionals } \\
\text { - Proactive and } \\
\text { transparent CMD } \\
\text { involvement }\end{array}$ & $\begin{array}{l}\text {-Interest in the community } \\
\text { supportive } \\
\text { - Tech park }\end{array}$ & & $\begin{array}{l}\text { - Low ad rates } \\
\text { - Local interest in FLW } \\
\text { activities }\end{array}$ \\
\hline 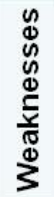 & $\begin{array}{l}\text {-Too many } \\
\text { communicators } \\
\text {-Mixed messages } \\
\text {-Inadequate/immature } \\
\text { STRATCOM }\end{array}$ & $\begin{array}{l}\text {-FLW TV is not seen off } \\
\text { post }\end{array}$ & & $\begin{array}{l}\text { - Lack of funds } \\
\text {-Technology upgrades }\end{array}$ \\
\hline 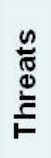 & $\begin{array}{l}\text { - Lack of } \\
\text { understanding of what } \\
\text { happens on FLW }\end{array}$ & $\begin{array}{l}\text { - Fear of the unknown } \\
\text { - Lack of interest }\end{array}$ & $\begin{array}{l}\text { Remote from } \\
\text { mass comm } \\
\text { (TV radio) (big } \\
\text { city) }\end{array}$ & \\
\hline 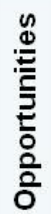 & - Tech park growth & $\begin{array}{l}\text { - Tech park } \\
\text { - LWI }\end{array}$ & $\begin{array}{l}\cdot \text { Tech } \\
\text { expansion }\end{array}$ & \\
\hline
\end{tabular}

Figure 10. SWOT analysis for Communication.

\begin{tabular}{|c|c|c|c|c|}
\hline & Mission & Community & Environment & Cost \\
\hline 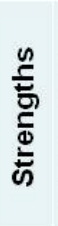 & $\begin{array}{l}\text { - } 3 \text { CASA(s) } \\
\text {-Multiple stakeholders } \\
\text { - CMD interest } \\
\text { - Liaisons w/ major } \\
\text { institutions } \\
\text { - LWI }\end{array}$ & $\begin{array}{l}\text { - Excellent spt and mutual } \\
\text { interaction } \\
\text { - Chairman SASC } \\
\text { - Most comm. Covenants }\end{array}$ & $\begin{array}{l}\text { - Our ENV branch } \\
\text { has positive } \\
\text { relationships w/ } \\
\text { state and regional } \\
\text { counterparts }\end{array}$ & $\begin{array}{l}\text { - Cost sharing wl } \\
\text { stakeholders (very } \\
\text { frequent) }\end{array}$ \\
\hline 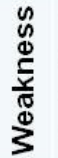 & $\begin{array}{l}\text { - CMD relationship w/ } \\
\text { stakeholders fluctuates } \\
\text { - Stakeholders interests } \\
\text { can conflict w/ ours }\end{array}$ & $\begin{array}{l}\text { - Multiple communities level } \\
\text { of engagement varies by } \\
\text { proximity and other factors }\end{array}$ & & \\
\hline 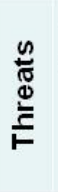 & $\begin{array}{l}\text {-Potential reduction of } \\
\text { stakeholder influence }\end{array}$ & $\begin{array}{l}\text { - Stakeholder specific } \\
\text { interests } \\
\text { - Lack of cooperation } \\
\text { between supported } \\
\text { stakeholders }\end{array}$ & & \\
\hline 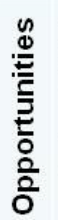 & $\begin{array}{l}\text {-Very high stakeholder } \\
\text { interest } \\
\text { - Tech park growth } \\
\text { - LWI } \\
\text { - UnivMO system }\end{array}$ & $\begin{array}{l}\text { - Tech park growth } \\
\text { - LWI } \\
\text {-Univ MO system }\end{array}$ & & \\
\hline
\end{tabular}

Figure 11. SWOT analysis for Stakeholder Engagement. 


\begin{tabular}{|c|c|c|c|c|}
\hline & Mission & Community & Environment & Cost \\
\hline 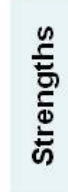 & $\begin{array}{l}\text { - Current } \\
\text { understanding of } \\
\text { necessity to market } \\
\text { command intent }\end{array}$ & $\begin{array}{l}\text { - Local communities } \\
\text { support \& understand } \\
\text { value of FLW \& potential } \\
\text { - Tourism Board }\end{array}$ & $\begin{array}{l}\text { - Outdoor } \\
\text { recreation } \\
\text { activities }\end{array}$ & $\begin{array}{l}\text { - Unique partnerships } \\
\text { as enablers, } \\
\text { leveraging technology } \\
\text { - No-cost partnerships } \\
\text { - Not } 4 \text { profits }\end{array}$ \\
\hline 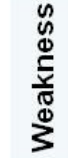 & $\begin{array}{l}\text { - STRATCOM needs } \\
\text { continued emphasis } \\
\text { - Not mature }\end{array}$ & $\begin{array}{l}\text { - Local communities have } \\
\text { limited ability to help } \\
\text { market outside } \\
\text { - Rural communities }\end{array}$ & $\begin{array}{l}\text { - Isolation } \\
\text {-MO laws } \\
\text { requiring env. } \\
\text { considerations }\end{array}$ & $\begin{array}{l}\text { - Difficult to get here } \\
\text { (travel) }\end{array}$ \\
\hline 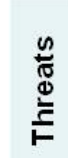 & $\begin{array}{l}\text { - Change in } \\
\text { leadership can } \\
\text { change perspective } \\
\text { on STRATCOM }\end{array}$ & $\begin{array}{l}\text { - Perceptions of community } \\
\text { about industry being on- } \\
\text { vs. off-post (tech park) } \\
\text { business enterprise }\end{array}$ & $\begin{array}{l}\text { Impact of } \\
\text { increase in } \\
\text { population }\end{array}$ & $\begin{array}{l}\text { - Cost of technology } \\
\text { increase }\end{array}$ \\
\hline 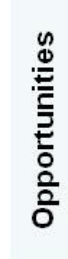 & $\begin{array}{l}\text { - Bringing industry \& } \\
\text { academia to FLW to } \\
\text { enhance soldier } \\
\text { readiness/training/ } \\
\text { survivability } \\
\text { capabilities thru tech } \\
\text { (tech park) }\end{array}$ & $\begin{array}{l}\text { - Help communities } \\
\text { improve general quality of } \\
\text { life thru growth, etc. } \\
\text { - Increase partnerships } \\
\text { - Political leadership is } \\
\text { under stakeholder } \\
\text { engagement }\end{array}$ & $\begin{array}{l}\text { - Quality of life } \\
\text { (outdoor } \\
\text { recreation) }\end{array}$ & $\begin{array}{l}\text { - Multiple Army/Joint } \\
\text { activities reduce } \\
\text { marketing costs } \\
\text { - Low TAX rates }\end{array}$ \\
\hline
\end{tabular}

Figure 12. SWOT analysis for Marketing FLW.

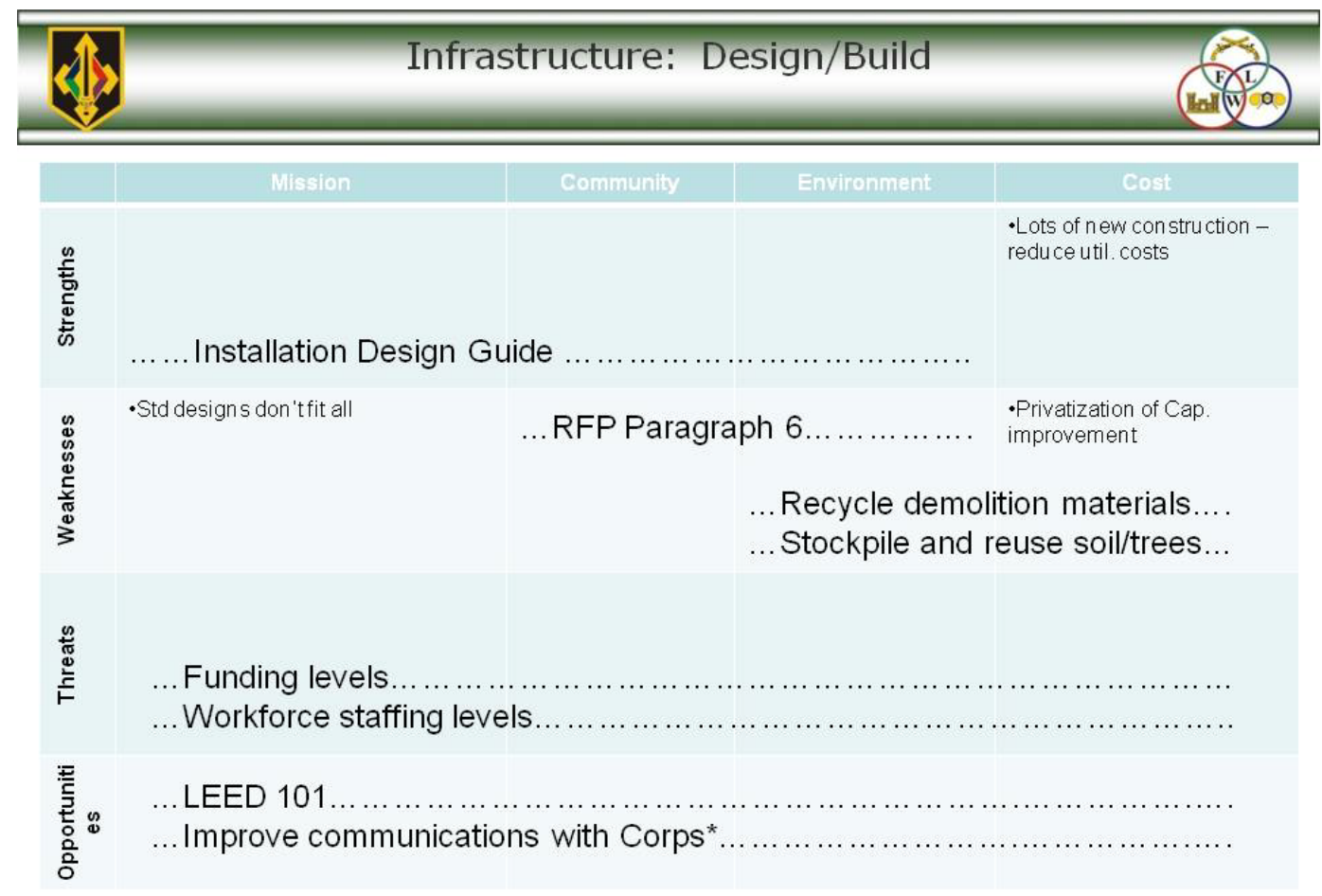

Figure 13. SWOT analysis for Design/Build. 


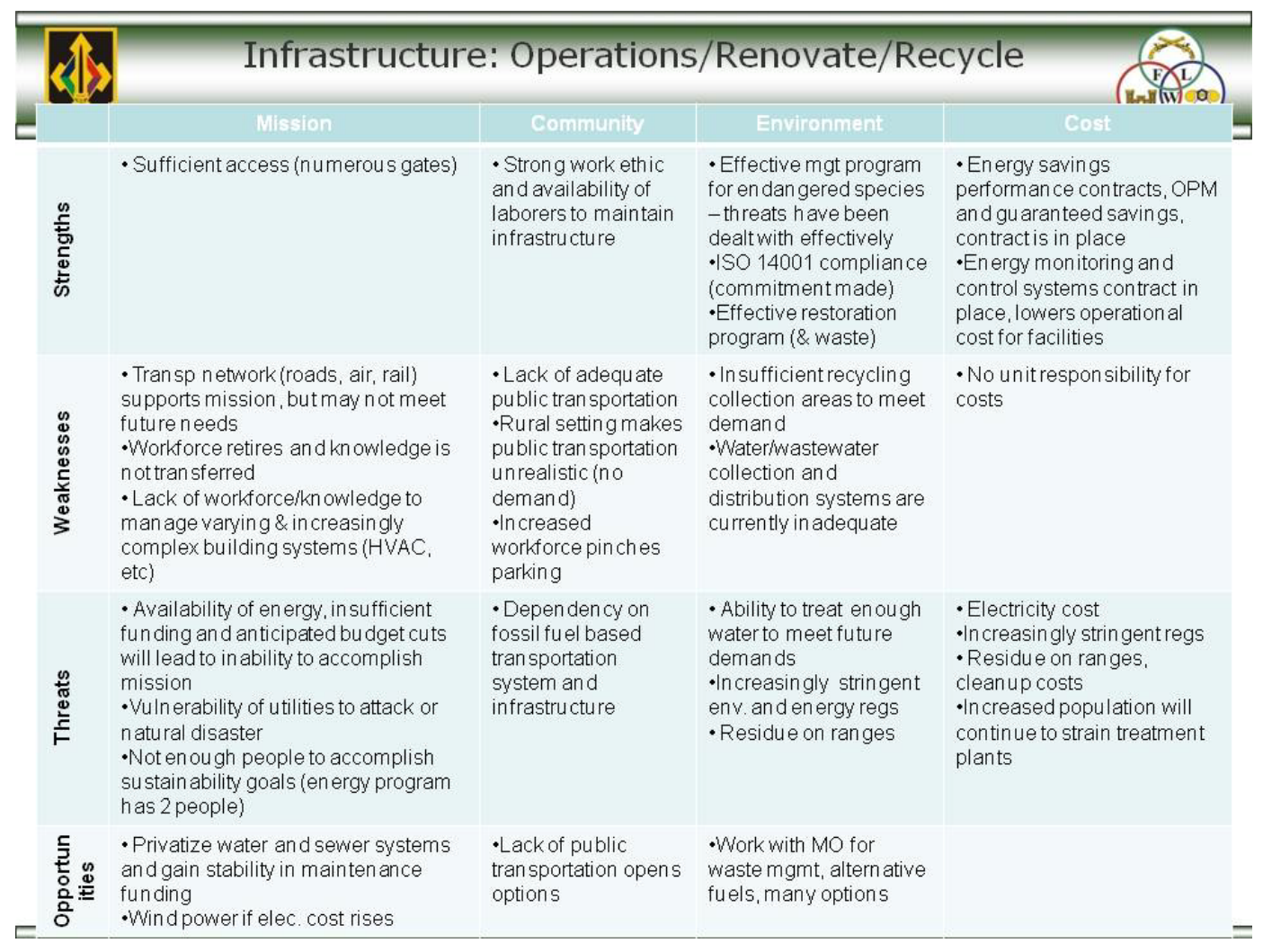

Figure 14. SWOT analysis for Operations/Renovate/Recycle.

\begin{tabular}{|c|c|c|c|c|}
\hline 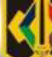 & \multicolumn{4}{|c|}{ Mission Services: Force Protection/Safety } \\
\hline & Mission & Community & Environment & Cost \\
\hline 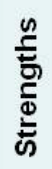 & $\begin{array}{l}\text { - Preparedness } \\
\text {-WMD-CST }\end{array}$ & $\begin{array}{l}\text { - Protection - a } \\
\text { sense of } \\
\text { safety/security }\end{array}$ & $\begin{array}{l}\text { - Wildland fire } \\
\text { response } \\
\text { - Hazmat } \\
\text { response }\end{array}$ & $\begin{array}{l}\text { - Availability of Borrowed } \\
\text { Mil Manpower } \\
\text { - Assets are secure } \\
\text { - MOA's }\end{array}$ \\
\hline 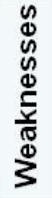 & $\begin{array}{l}\text { - Access control } \\
\text { (timeliness) due to } \\
\text { congestion }\end{array}$ & $\begin{array}{l}\text { - Limited or restricted } \\
\text { access to hospital } \\
\text { and other services }\end{array}$ & - Fuel use & $\begin{array}{l}\text { - Budget constraints, } \\
\text { hiring freeze, } \\
\text { police/fire/guards } \\
\text { - Reduced services IAW } \\
\text { common levels of support }\end{array}$ \\
\hline 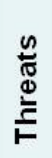 & $\begin{array}{l}\text { - Terrorist groups } \\
\text { - General criminal }\end{array}$ & $\begin{array}{l}\text { - Terrorist groups } \\
\text { - General criminal }\end{array}$ & $\begin{array}{l}\text { - Quality of life } \\
\text {-Weather, } \\
\text { tornadoes }\end{array}$ & - Loss/reduced funding \\
\hline 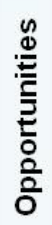 & $\begin{array}{l}\text { - MOA with off-post } \\
\text { agencies } \\
\text { - Relationships with } \\
\text { off-post leadership }\end{array}$ & $\begin{array}{l}- \text { Training - use of } \\
\text { facilities, instructors }\end{array}$ & $\begin{array}{l}\text { - Employment } \\
\text { - Individual } \\
\text { preparedness } \\
\text { - Mutual aid }\end{array}$ & $\begin{array}{l}\text { - Interagency cooperation, } \\
911 \text { thru MOA }\end{array}$ \\
\hline
\end{tabular}

Figure 15. SWOT analysis for Force Protection/Safety. 


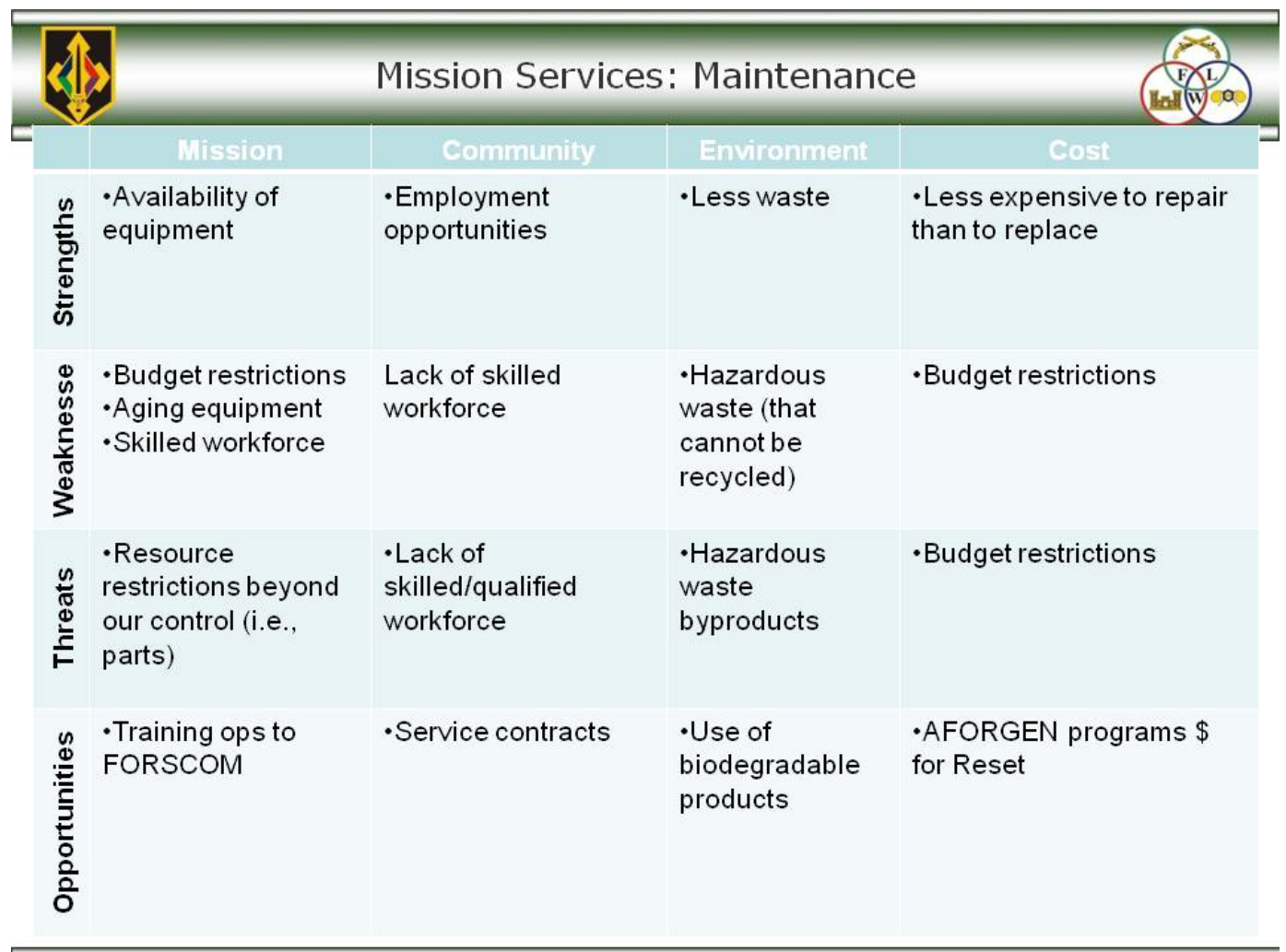

Figure 16. SWOT analysis for Maintenance.

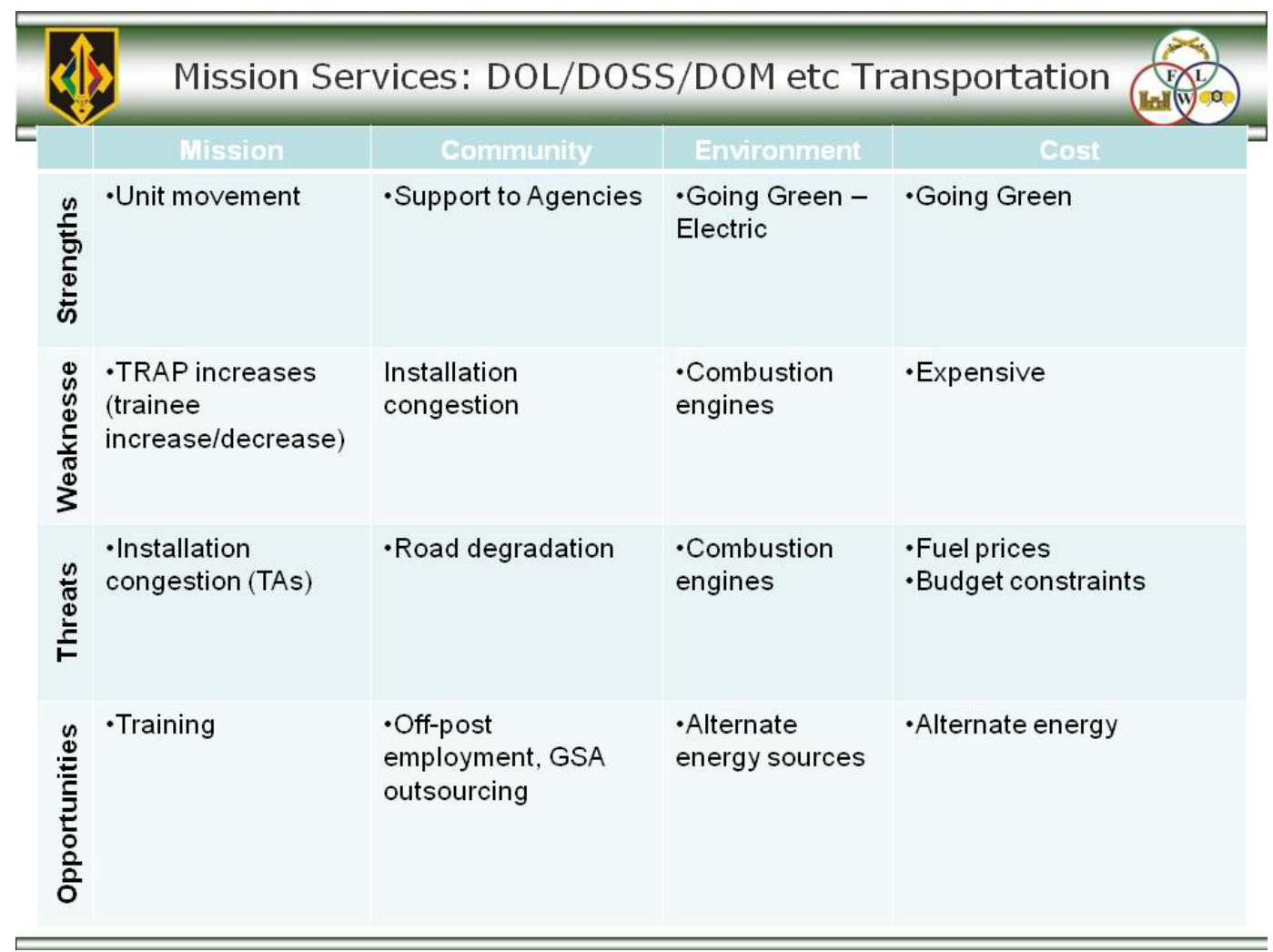

Figure 17. SWOT analysis for Transportation. 


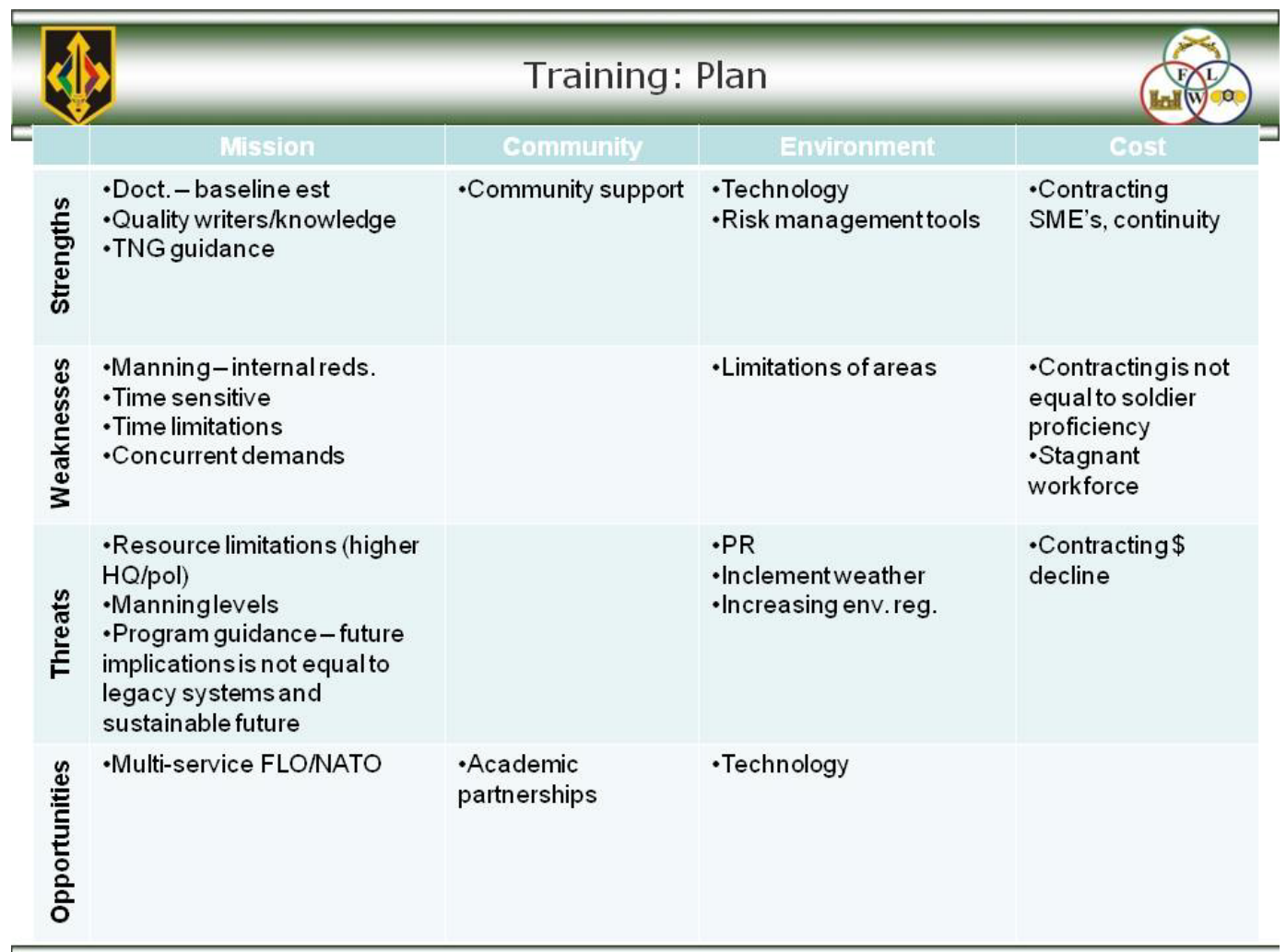

Figure 18. SWOT analysis for Training: Plan.

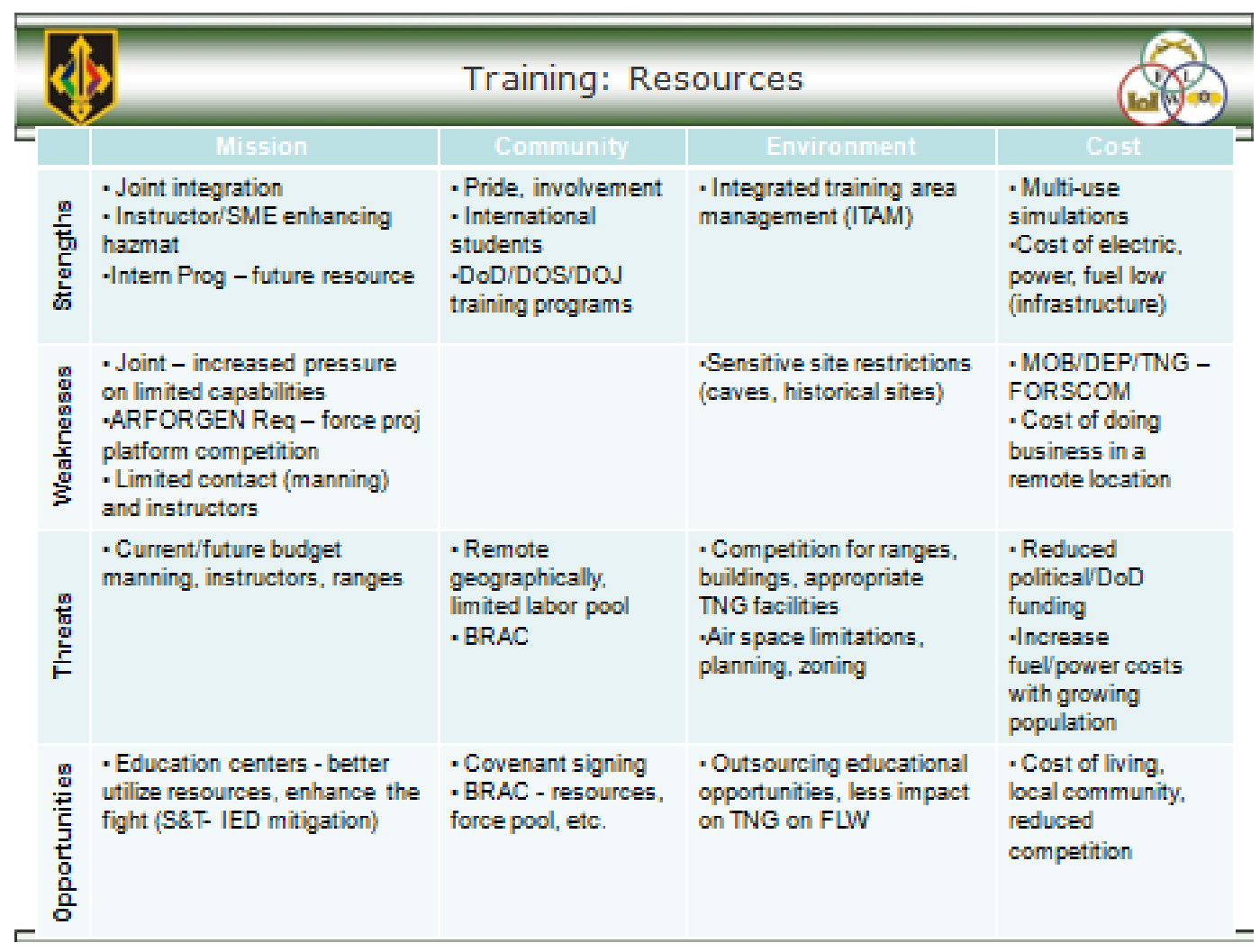

Figure 19. SWOT analysis for Training: Resources. 


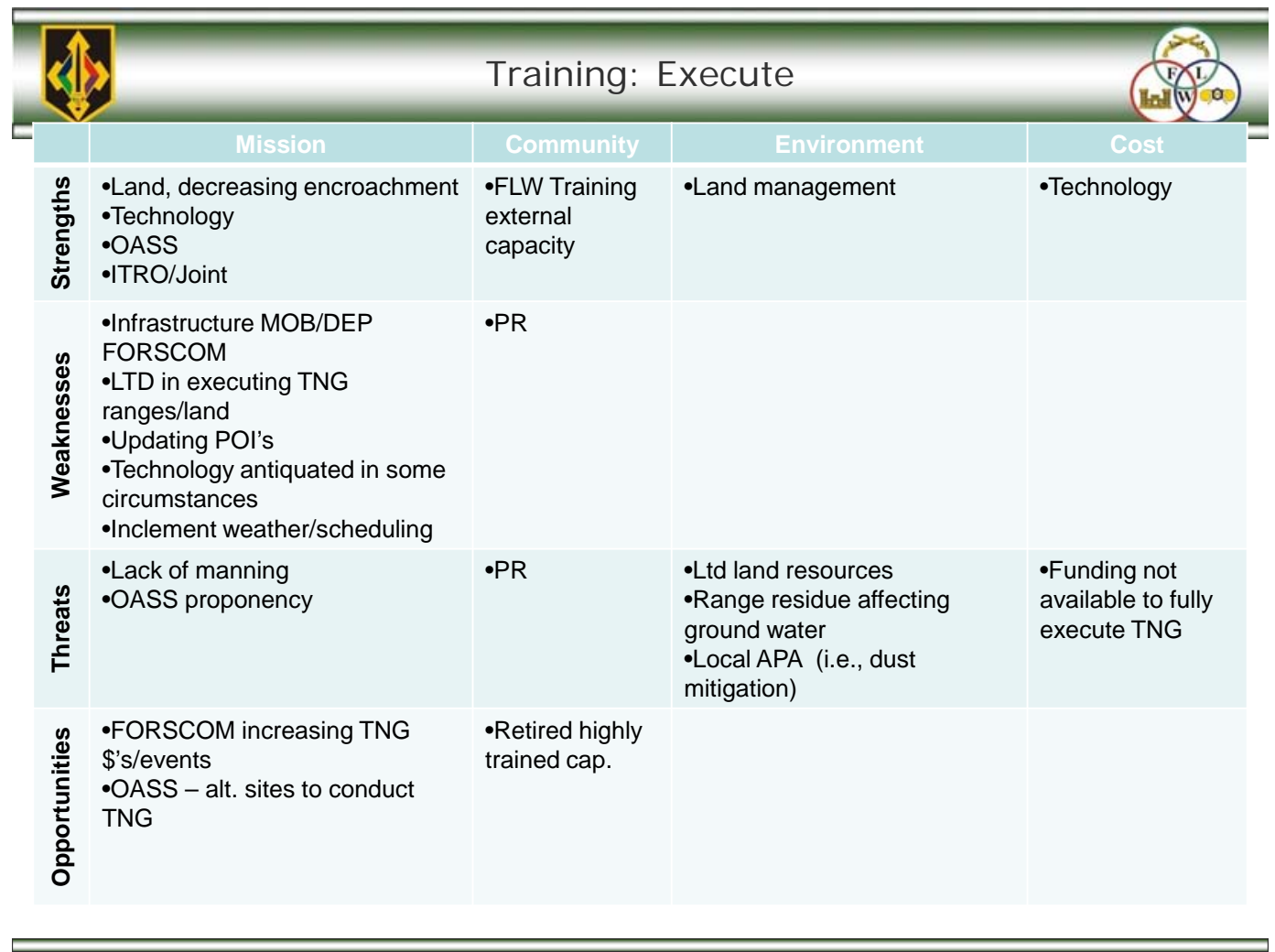

Figure 20. SWOT analysis for Training: Execution.

\begin{tabular}{|c|c|c|c|c|}
\hline 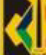 & \multicolumn{4}{|c|}{ Training: Assess } \\
\hline & Mission & Community & Environment & Cost \\
\hline 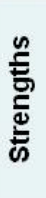 & $\begin{array}{l}\text { - EstablishedQAE staff (internal } \\
\text { \& external) }\end{array}$ & $\begin{array}{l}\text { - Reinforced } \\
\text { positive } \\
\text { relationsw/ } \\
\text { community that } \\
\text { we are } \\
\text { enforcing }\end{array}$ & $\begin{array}{l}\text {-Range control ensures } \\
\text { procedural compliancew/ } \\
\text { environmental regs }\end{array}$ & $\begin{array}{l}\text {-Minimizes fines } \\
\text {-Preserves } \\
\text { resources }\end{array}$ \\
\hline 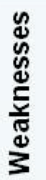 & $\begin{array}{l}\text { - Lack of manning \& skillsets for } \\
\text { inspectors } \\
\text { - Inspected org perceives as a } \\
\text { training distractor }\end{array}$ & & & \\
\hline 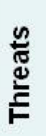 & $\begin{array}{l}\text {-QA has not been inspected in } \\
\text { some years }\end{array}$ & & & $\begin{array}{l}\text { - Lessonslearned } \\
\text { labor not funded } \\
\text { by CAC } \\
\text { - Funding }\end{array}$ \\
\hline 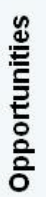 & $\begin{array}{l}\text {-Shared "best practices"w/Cdrs } \\
\text { - unit improvement }\end{array}$ & $\begin{array}{l}\text {-PAO ensures } \\
\text { positive } \\
\text { assessments } \\
\text { perceives local } \\
\text { media coverage }\end{array}$ & & \\
\hline
\end{tabular}

Figure 21. SWOT analysis for Training: Assessment. 


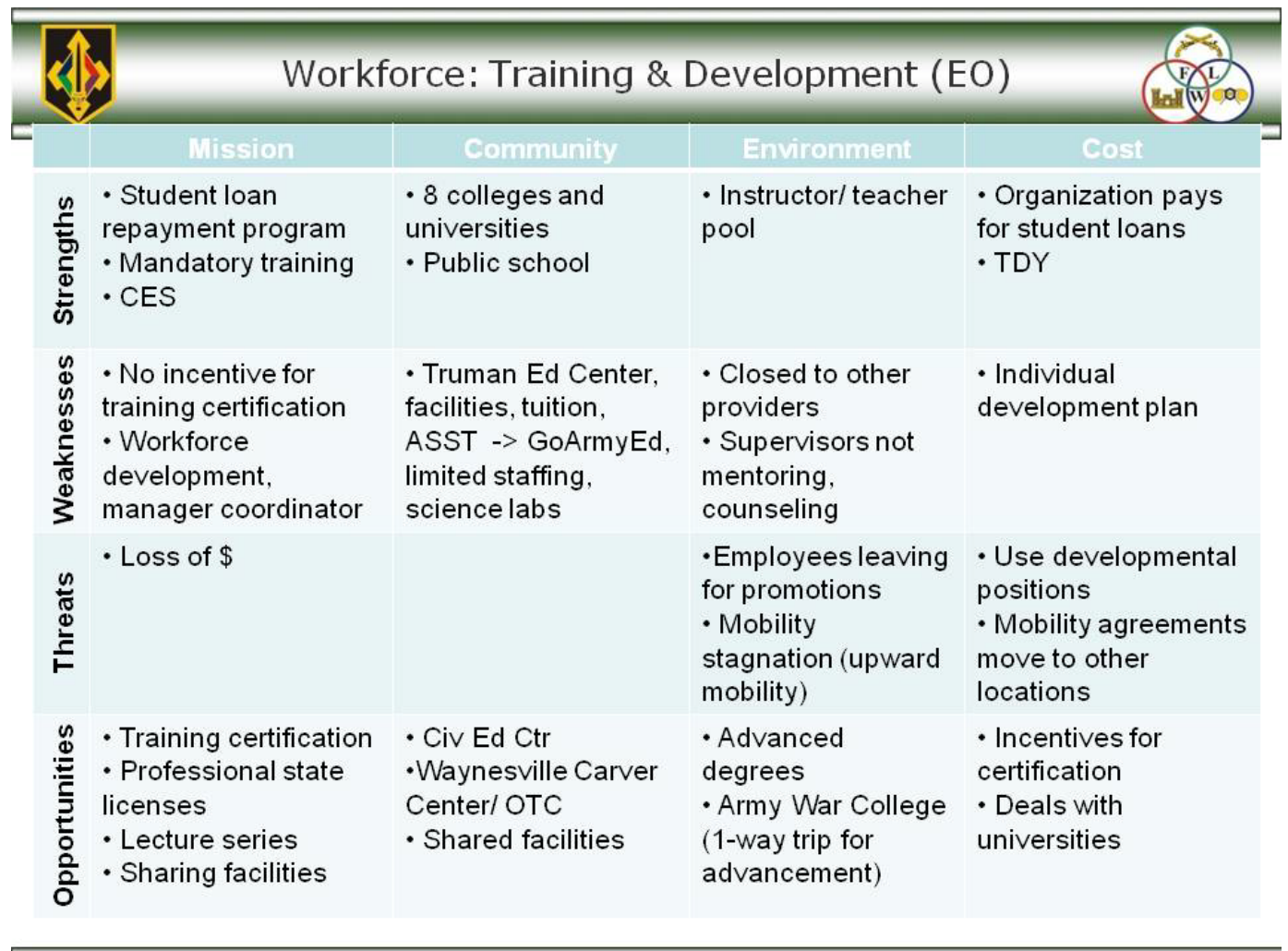

Figure 22. SWOT analysis for Workforce: Training and Development.

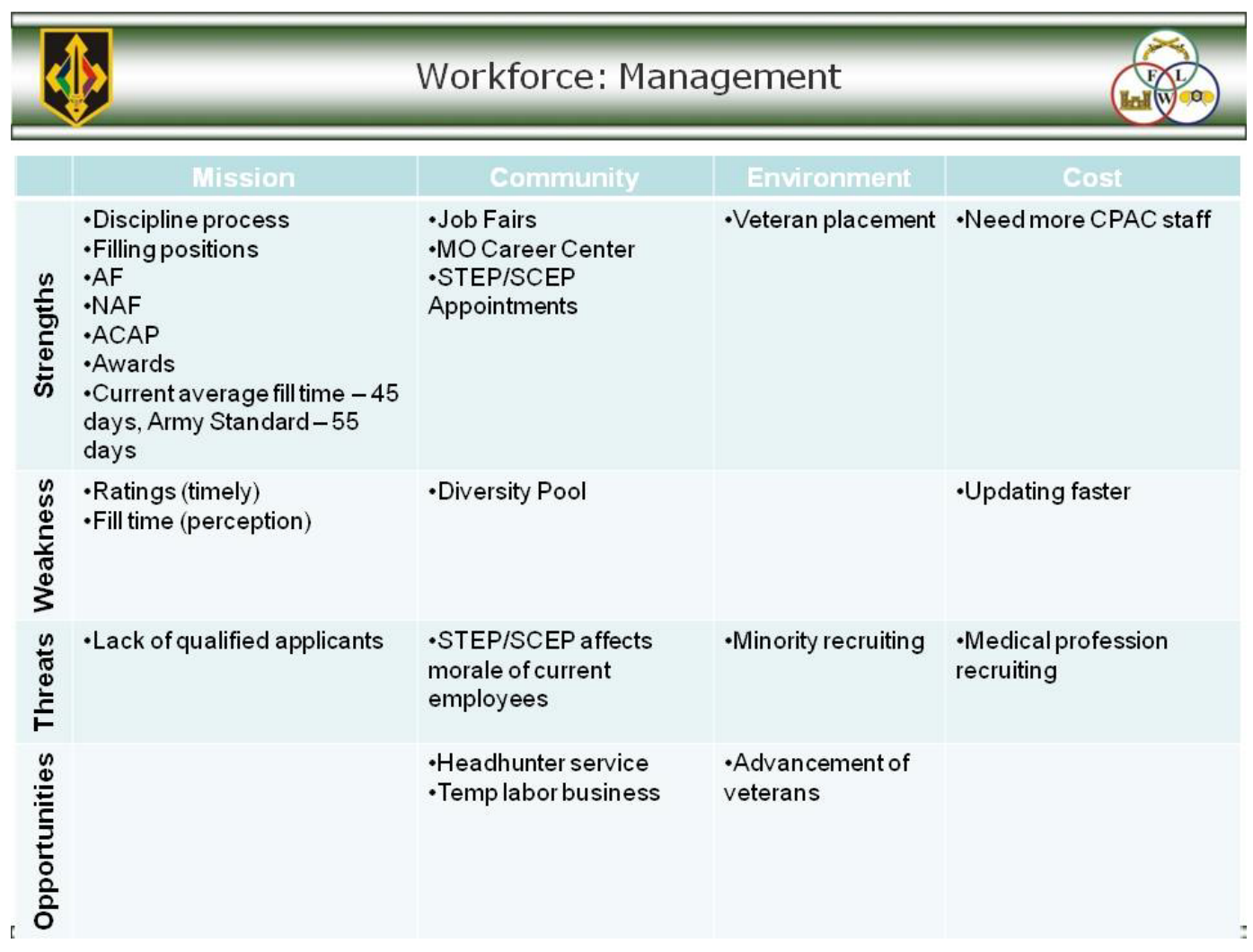

Figure 23. SWOT analysis for Workforce: Management. 


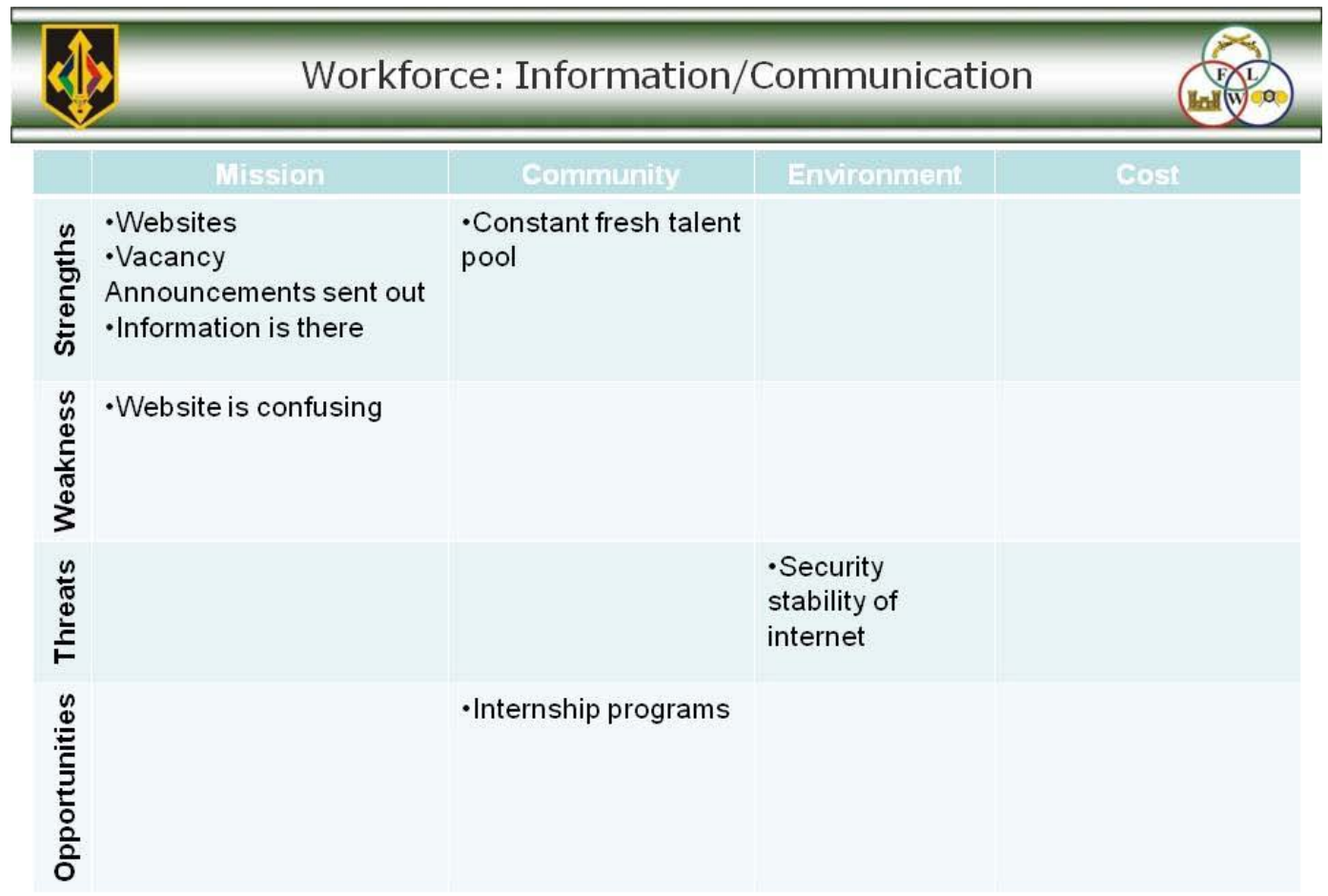

Figure 24. SWOT analysis for Workforce: Information/Communication.

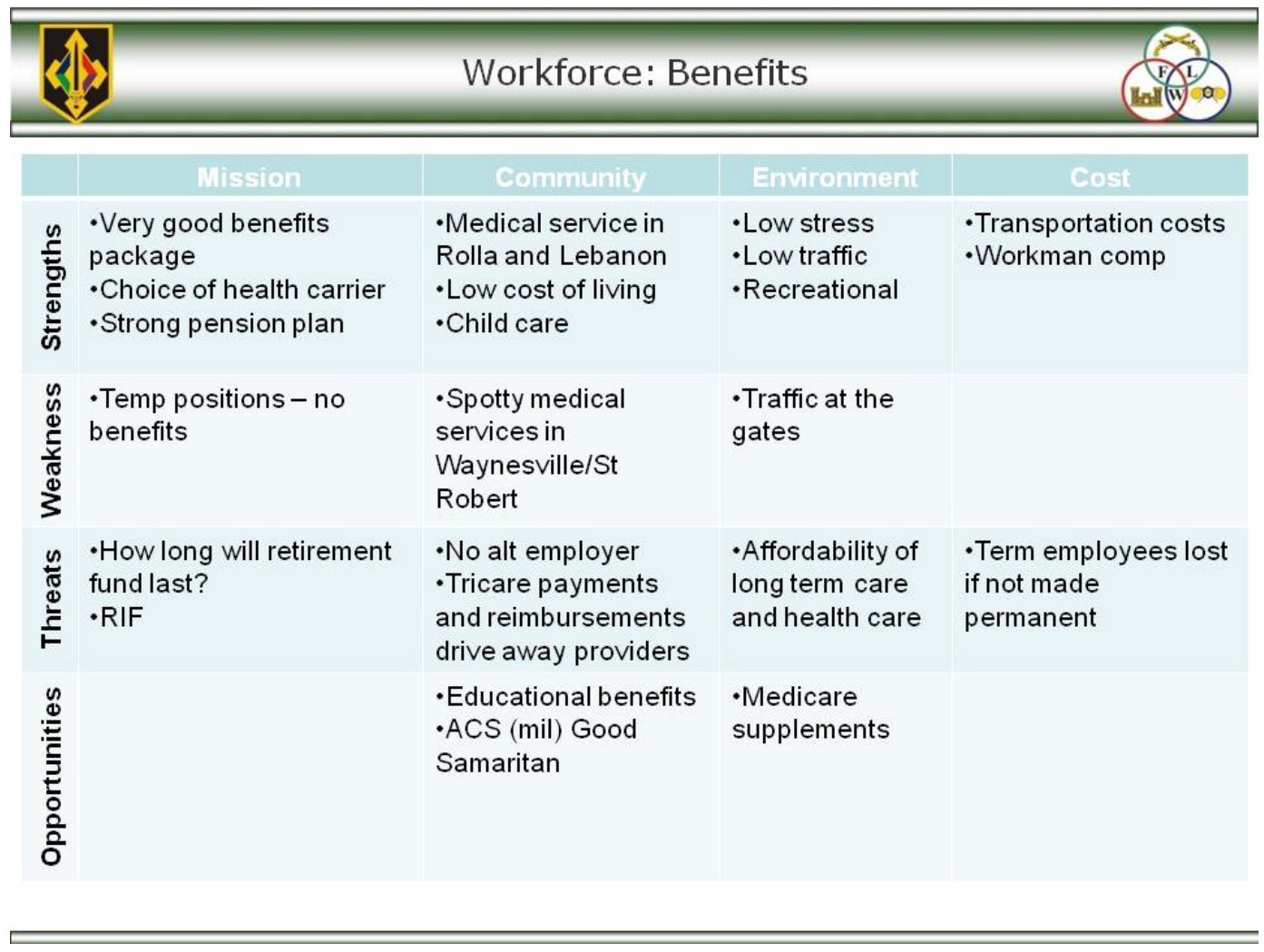

Figure 25. SWOT analysis for Workforce: Benefits. 


\section{Appendix B: Action Plans}

The following action plans identify estimated actions, timelines, and resource requirements (i.e., FTEs and/ or dollar amounts) needed to achieve the respective objectives. It is anticipated these action plans may be revised in an effort to achieve the objectives, and ultimately, the strategic sustainability goals of FLW (Table 27 - Table 38). 
Goal 1 Description: Fort Leonard Wood will, in the next 25 years, transform into an installation with an efficient network of high performance, sustainable, and resilient infrastructure systems enabling mission assurance and mission expansion.
Total FTE Required for Goal 1: 1.6 FTE in FY11, approx. 5.0 FTE in FY12, approx. 4.0 FTE/yr in FY13-15, 4.7 FTE/yr in FY16, 3.5 FTE/yr in FY17-19, and 5.7 FTE/yr in FY20-36.

Total Funding Required for Goal 1: \$550k in FY11, approx. \$1.97M in FY12, \$725k in FY13, \$475k in FY14, \$225/yr in FY15-16, and \$125k/yr in FY17-36.

Objective 1.1: Buildings in Campus setting that employ high-performance and adaptable systems to progressively reduce the use of nonrenewable resources.

Description: A community of smartly placed buildings in a campus setting that best supports the mission, which will occur while the following takes place:

- Minimizing on-post vehicle use;

- Reducing the loss of training land to cantonment area development;

- Taking advantage of on-post renewable power generation;

- Using distributed energy micro-grids; and

- Maximizing accessibility to services and creating a pedestrian-friendly FLW community.

\section{Lead/Proponent: DPW}

FTE Required for Obj.1.1: 0.2 FTE in 1Q FY12 - 2 Q FY13 to support installation master planning for storm water; 1.0 FTE in $4 Q$ FY12 - 2036 to support sustainable development and transportation.

Funding Required for Obj. 1.1: \$300k in FY12 to develop sustainable master plan (visioning); \$550k in FY12 for Capital Improvement Strategy (Facilities Baseline), storm water plan, and revised IDG; and \$250k in FY13 for transportation plan and \$250k/yr in FY13 and FY14 for Environmental Assessment.

\begin{tabular}{|c|c|c|c|c|c|c|c|c|c|c|c|c|c|c|c|c|}
\hline Actions for Objective 1.1 & $\begin{array}{c}\text { Lead/ } \\
\text { Proponent }\end{array}$ & $\begin{array}{l}\text { Funding } \\
\text { Required }\end{array}$ & $\begin{array}{l}\text { Add'I FTE } \\
\text { Required }\end{array}$ & $\begin{array}{l}\mathrm{FY} \\
12\end{array}$ & $\begin{array}{l}\text { FY } \\
13\end{array}$ & $\begin{array}{l}\text { FY } \\
14\end{array}$ & $\begin{array}{l}\text { FY } \\
15\end{array}$ & $\begin{array}{l}\mathrm{FY} \\
16\end{array}$ & $\begin{array}{l}\text { FY } \\
17\end{array}$ & $\begin{array}{l}\text { FY } \\
18\end{array}$ & $\begin{array}{l}\text { FY } \\
19\end{array}$ & $\begin{array}{l}\mathrm{FY} \\
20\end{array}$ & $\begin{array}{l}F Y \\
25\end{array}$ & $\begin{array}{l}\text { FY } \\
30\end{array}$ & $\begin{array}{l}\text { FY } \\
35\end{array}$ & $\begin{array}{l}\text { FY } \\
36\end{array}$ \\
\hline $\begin{array}{l}\text { Update Master Plan for Sustainable Development and } \\
\text { Net Zero design. Identify future cantonment area for } \\
\text { growth as part of the Campus-driven Master Plan. }\end{array}$ & DPW MP & $\begin{array}{l}\$ 800 k \text { (in } \\
\text { place) }\end{array}$ & $\begin{array}{l}\text { Sust. } \\
\text { Design } \\
\text { Eng. } \\
\text { (see Obj. } \\
1.3 \text { ) } \\
\end{array}$ & $2 \mathrm{Q}$ & $2 \mathrm{Q}$ & & & & & & & & & & & \\
\hline Define Zoning as part of Master Plan Development & DPW MP & None & & $2 \mathrm{Q}$ & $2 \mathrm{Q}$ & & & & & & & & & & & \\
\hline Insert Resiliency Campus into Master Plan & DPW MP & None & & $2 \mathrm{Q}$ & $2 \mathrm{Q}$ & & & & & & & & & & & \\
\hline
\end{tabular}




\begin{tabular}{|c|c|c|c|c|c|c|c|c|c|c|c|c|c|c|c|c|}
\hline Actions for Objective 1.1 & $\begin{array}{l}\text { Lead/ } \\
\text { Proponent }\end{array}$ & $\begin{array}{l}\text { Funding } \\
\text { Required }\end{array}$ & $\begin{array}{l}\text { Add'I FTE } \\
\text { Required }\end{array}$ & $\begin{array}{l}\mathrm{FY} \\
12\end{array}$ & $\begin{array}{l}\mathrm{FY} \\
13\end{array}$ & $\begin{array}{l}\text { FY } \\
14\end{array}$ & $\begin{array}{l}\text { FY } \\
15\end{array}$ & $\begin{array}{l}\text { FY } \\
16\end{array}$ & $\begin{array}{l}\text { FY } \\
17\end{array}$ & $\begin{array}{l}\text { FY } \\
18\end{array}$ & $\begin{array}{l}\text { FY } \\
19\end{array}$ & $\begin{array}{l}\text { FY } \\
20\end{array}$ & $\begin{array}{l}\mathrm{FY} \\
25\end{array}$ & $\begin{array}{l}\text { FY } \\
30\end{array}$ & $\begin{array}{l}\mathrm{FY} \\
35\end{array}$ & $\begin{array}{l}\text { FY } \\
36\end{array}$ \\
\hline $\begin{array}{l}\text { Complete Master Plan Programmatic Environmental As- } \\
\text { sessment. }\end{array}$ & DPW MP & $\begin{array}{l}\$ 250 \mathrm{k} / \mathrm{yr} \\
\text { in FY13 } \\
\text { and } \\
\text { FY14 }\end{array}$ & & & $2 \mathrm{Q}$ & $4 \mathrm{Q}$ & & & & & & & & & & \\
\hline $\begin{array}{l}\text { Integrate recommendations of the water and waste water } \\
\text { study into the Master Plan. [Ongoing effort.] }\end{array}$ & $\begin{array}{l}\text { DPW Env } \\
\text { \& MP }\end{array}$ & $\begin{array}{l}\text { (Already } \\
\text { funded) }\end{array}$ & & $4 \mathrm{Q}$ & $3 Q$ & & & & & & & & & & & \\
\hline $\begin{array}{l}\text { Develop and integrate Installation Storm water Mgmt } \\
\text { Plan into Installation MP: 1) Calculate pre-development } \\
\text { hydrology baseline per EPA guidance; 2) Develop strate- } \\
\text { gies and approaches FLW will use to meet standard; 3) } \\
\text { Integrate into IDG and contracts -- identify pilot projects } \\
\text { for FLW; 4) Develop SOP to test emerging technologies; } \\
\text { 5) Integrate results into DD Form 1391s. }\end{array}$ & $\begin{array}{l}\text { DPW Env } \\
\quad \& \text { MP }\end{array}$ & $\$ 300 k$ & $\begin{array}{l}.2 \text { to } \\
\text { monitor } \\
\text { imp. }\end{array}$ & $1 \mathrm{Q}$ & $2 \mathrm{Q}$ & & & & & & & & & & & \\
\hline $\begin{array}{l}\text { Develop baseline of inadequate facilities to demolish } \\
\text { (unneeded / sub-standard facilities per IMCOM CMP IR3- } \\
1 \text { and EO 13514). To do this: develop a triple-bottom-line } \\
\text { protocol for assessing facilities performance with respect } \\
\text { to mission, workforce well-being, resource consumption, } \\
\text { location, cost to maintain, and general utility; compile } \\
\text { data to support evaluation; and evaluate buildings. }\end{array}$ & DPW MP & $\$ 250 k$ & $\begin{array}{l}\text { Sust. } \\
\text { Design } \\
\text { Eng. } \\
\text { (see Obj. } \\
\text { 1.3) }\end{array}$ & $1 \mathrm{Q}$ & $3 Q$ & & & & & & & & & & & \\
\hline $\begin{array}{l}\text { Develop plan / process for repurposing / reusing existing } \\
\text { facilities to best suit mission requirements and reduce } \\
\text { need for new construction. Identify alternatives to renova- } \\
\text { tion to reduce existing assets deferred-maintenance } \\
\text { costs, as per EO } 13514 \text {. }\end{array}$ & DPW MP & & $\begin{array}{l}\text { Sust. } \\
\text { Design } \\
\text { Eng. } \\
\text { (see Obj. } \\
\text { 1.3) }\end{array}$ & $2 \mathrm{Q}$ & & & & & & & & & & & & \\
\hline $\begin{array}{l}\text { Revise Master Plan to ensure planning for new facili- } \\
\text { ties/leases considers pedestrian-friendly sites near exist- } \\
\text { ing employment centers and accessible to public: }\end{array}$ & DPW MP & $\begin{array}{l}\$ 250 k \\
\text { FY13 }\end{array}$ & $\begin{array}{l}1.0 \\
\text { (Trans- } \\
\text { portation } \\
\text { Planner) }\end{array}$ & $4 Q$ & & \multicolumn{11}{|c|}{$\begin{array}{l}\text { Transportation Planner continues to support installation after } \\
\text { plan is completed. }\end{array}$} \\
\hline $\begin{array}{l}\text { - Develop a comprehensive transportation plan that } \\
\text { supports a campus development strategy. Integrate into } \\
\text { revised Master Plan. }\end{array}$ & DPW MP & & & $4 \mathrm{Q}$ & & & & & & & & & & & & \\
\hline $\begin{array}{l}\text { - Include regional mass transportation development into } \\
\text { transportation master plan. Coordinate with Regional } \\
\text { Cooperation (Goal 3) team to coordinate with community } \\
\text { efforts. Use plan and development patterns to create } \\
\text { incentives to use mass transit options. }\end{array}$ & DPW MP & & & & $1 \mathrm{Q}$ & & & & & & & & & & & \\
\hline
\end{tabular}




\begin{tabular}{|c|c|c|c|c|c|c|c|c|c|c|c|c|c|c|c|c|}
\hline Actions for Objective 1.1 & $\begin{array}{l}\text { Lead/ } \\
\text { Proponent }\end{array}$ & $\begin{array}{l}\text { Funding } \\
\text { Required }\end{array}$ & $\begin{array}{l}\text { Add'I FTE } \\
\text { Required }\end{array}$ & $\begin{array}{l}\mathrm{FY} \\
12\end{array}$ & $\begin{array}{l}\mathrm{FY} \\
13\end{array}$ & $\begin{array}{l}\text { FY } \\
14\end{array}$ & $\begin{array}{l}\mathrm{FY} \\
15\end{array}$ & $\begin{array}{l}\mathrm{FY} \\
16\end{array}$ & $\begin{array}{l}\mathrm{FY} \\
17\end{array}$ & $\begin{array}{l}\mathrm{FY} \\
18\end{array}$ & $\begin{array}{l}\mathrm{FY} \\
19\end{array}$ & $\begin{array}{l}\mathrm{FY} \\
20\end{array}$ & $\begin{array}{l}\mathrm{FY} \\
25\end{array}$ & $\begin{array}{l}\mathrm{FY} \\
\mathbf{3 0}\end{array}$ & $\begin{array}{l}\mathrm{FY} \\
35\end{array}$ & $\begin{array}{l}\mathrm{FY} \\
36\end{array}$ \\
\hline $\begin{array}{l}\text { - Redevelop transportation system as part of the sus- } \\
\text { tainable development effort to improve traffic flow to re- } \\
\text { lieve congestion and reduce trip time. }\end{array}$ & DPW MP & & & $4 Q$ & & & & & & & & & & & & \\
\hline $\begin{array}{l}\text { - Integrate bike, troop, and pedestrian network into MP } \\
\text { development pattern and transportation system. }\end{array}$ & DPW MP & & & $4 Q$ & & & & & & & & & & & & \\
\hline $\begin{array}{l}\text { - Develop transportation network to better connect } \\
\text { training sites to barracks. }\end{array}$ & DPW MP & & & $4 Q$ & & & & & & & & & & & & \\
\hline $\begin{array}{l}\text { Coordinate with DOL to identify alternative fuel system } \\
\text { infrastructure needs and integrate into the Master Plan } \\
\text { as needed. }\end{array}$ & $\begin{array}{l}\text { DPW MP } \\
\& \text { DOL }\end{array}$ & & & & & & & & & & & & & & & \\
\hline $\begin{array}{l}\text { Identify and integrate into the Master Plan areas to sup- } \\
\text { port sustainable community activities (e.g., community } \\
\text { gardens, open space, and habitat protection. }\end{array}$ & $\begin{array}{l}\text { DPW MP } \\
\text { \& DPW } \\
\text { ENV }\end{array}$ & & & $4 Q$ & & & & & & & & & & & & \\
\hline
\end{tabular}


Goal 1 Description: Fort Leonard Wood will, in the next 25 years, transform into an installation with an efficient network of high-performance, sustainable, and resilient infrastructure systems enabling mission assurance and mission expansion.

Objective 1.2: Efficient use and management of energy and water that is provided from cost-competitive, secure, and renewable sources.

Description: Institutionalize energy and water savings by using conservation procedures and technologies throughout FLW. FLW heats primarily with natural gas which is a nonrenewable source. There are also cost and security issues to consider with this energy source. FLW will develop an energy production and management portfolio that will:

- Provide a mix of purchased and self-produced, conventional and renewable energy sources;

- Explore and pursue on-site power production that will support development of sustainable power generation and use patterns;

- Be integrated into designed facilities that can use recovered heat from energy production

- Exploit renewable on-post power sources like bio-mass, solar, waste-to-heat, and co-generation;

- Integrate micro-grids into future development as well as improved and efficient transmission technologies; and

- Support the evolution of Fort Leonard Wood to a net-zero Installation.

- Reaching the goal of efficient use of energy (and water) must include education/outreach to all Soldiers, Families, civilians, and contractors.

\section{Lead/Proponent: DPW Energy Manager}

FTE Required for Obj. 1.2: 0.7 FTE in 3Q FY11, approximately 3.0 FTE in 4Q FY11-3Q FY12, approximately 1.0 FTE in 4Q FY12-4Q FY15, 2.7 FTE in FY16, 0.5 FTE in FY17-19, and 2.7 FTE in FY20-36.

Funding Required for Obj. 1.2: \$350k in FY11, \$790k in FY12, \$200k/yr in FY13-16, and \$100k/yr in FY17-36.

\begin{tabular}{|c|c|c|c|c|c|c|c|c|c|c|c|c|c|c|c|c|c|}
\hline Actions for Objective 1.2 & $\begin{array}{c}\text { Lead / } \\
\text { Proponent }\end{array}$ & $\begin{array}{l}\text { Funding } \\
\text { Required }\end{array}$ & $\begin{array}{l}\text { Add'I } \\
\text { FTE } \\
\text { Required }\end{array}$ & $\begin{array}{l}\mathrm{FY} \\
11\end{array}$ & $\begin{array}{l}F Y \\
12\end{array}$ & $\begin{array}{l}\mathrm{FY} \\
13\end{array}$ & $\begin{array}{l}\mathrm{FY} \\
14\end{array}$ & $\begin{array}{l}\mathrm{FY} \\
15\end{array}$ & $\begin{array}{l}\mathrm{FY} \\
16\end{array}$ & $\begin{array}{l}\text { FY } \\
17\end{array}$ & $\begin{array}{l}\mathrm{FY} \\
18\end{array}$ & $\begin{array}{l}\mathrm{FY} \\
19\end{array}$ & $\begin{array}{l}\text { FY } \\
20\end{array}$ & $\begin{array}{l}\mathrm{FY} \\
25\end{array}$ & $\begin{array}{l}\text { FY } \\
30\end{array}$ & $\begin{array}{l}\text { FY } \\
35\end{array}$ & $\begin{array}{l}\text { FY } \\
36\end{array}$ \\
\hline $\begin{array}{l}\text { Meter representative number of types of buildings, under } \\
29,000 \text { sq. } \mathrm{ft} . \text {, to compare / baseline performance for new small } \\
\text { constructions (OMA-funded). (ON-GOING) }\end{array}$ & $\begin{array}{l}\text { DPW Ener- } \\
\text { gy \& Env }\end{array}$ & $\begin{array}{l}\text { OMA Fund- } \\
\text { ing }\end{array}$ & 0.1 & $3 Q$ & & $4 Q$ & & & & & & & & & & & \\
\hline $\begin{array}{l}\text { Install energy meters by } 1 \text { October } 2012 \text { IAW EPAct } 2005 . \\
\text { [Phase I is ongoing; Phase II starts 4Q12.] }\end{array}$ & $\begin{array}{l}\text { DPW Ener- } \\
\text { gy }\end{array}$ & $\begin{array}{l}\$ 400 k \\
\text { Phase II }\end{array}$ & $\begin{array}{l}0.1 \text { for } \\
\text { oversight }\end{array}$ & & 10 & & & & & & & & & & & & \\
\hline Install water meters & DPW & & & & & 10 & & $4 Q$ & & & & & & & & & \\
\hline Work with CERL to streamline data assessment and monitoring & DPW & & & & $2 Q$ & & & & & & & & & & & & \\
\hline
\end{tabular}




\begin{tabular}{|c|c|c|c|c|c|c|c|c|c|c|c|c|c|c|c|c|c|}
\hline Actions for Objective 1.2 & $\begin{array}{l}\text { Lead / } \\
\text { Proponent }\end{array}$ & $\begin{array}{l}\text { Funding } \\
\text { Required }\end{array}$ & $\begin{array}{l}\text { Add'I } \\
\text { FTE } \\
\text { Required }\end{array}$ & $\begin{array}{l}\text { FY } \\
11\end{array}$ & $\begin{array}{l}\mathrm{FY} \\
12\end{array}$ & $\begin{array}{l}\text { FY } \\
13\end{array}$ & $\begin{array}{l}\mathrm{FY} \\
14\end{array}$ & $\begin{array}{l}\text { FY } \\
15\end{array}$ & $\begin{array}{l}\mathrm{FY} \\
16\end{array}$ & $\begin{array}{l}\text { FY } \\
17\end{array}$ & $\begin{array}{l}\mathrm{FY} \\
18\end{array}$ & $\begin{array}{l}\text { FY } \\
19\end{array}$ & $\begin{array}{l}\text { FY } \\
20\end{array}$ & $\begin{array}{l}\text { FY } \\
25\end{array}$ & $\begin{array}{l}\text { FY } \\
30\end{array}$ & $\begin{array}{l}\text { FY } \\
35\end{array}$ & $\begin{array}{l}\text { FY } \\
36\end{array}$ \\
\hline \multicolumn{18}{|l|}{$\begin{array}{l}\text { protocols to identify means to tie occupant behavior to energy } \\
\text { consumption. }\end{array}$} \\
\hline $\begin{array}{l}\text { Incorporate government and ESCO monitoring systems to pro- } \\
\text { vide a single Utility Mgmt Control System (UMCS) that controls } \\
\text { and reduces energy and water use. One report for all energy } \\
\text { and water. }\end{array}$ & ESCO & $\begin{array}{l}\text { ESCO to } \\
\text { provide } \\
\text { cost }\end{array}$ & $\begin{array}{l}0.1 \text { for } \\
\text { oversight }\end{array}$ & & $3 Q$ & 10 & & & & & & & & & & & \\
\hline $\begin{array}{l}\text { Integrate energy and water management accountability into the } \\
\text { job performance objectives of key individuals at the installation. }\end{array}$ & DGC/CPAC & & & & 30 & $1 Q$ & & & & & & & & & & & \\
\hline $\begin{array}{l}\text { Develop comprehensive energy security plan to develop on-site } \\
\text { power generation portfolio that defines impacts associated with } \\
\text { energy use, identifies optimal renewable power options and } \\
\text { emerging (viable) technologies. Integrate into the installation } \\
\text { Master Plan. Energy portfolio plan should: }\end{array}$ & $\begin{array}{l}\text { DPW Ener- } \\
\text { gy \& MP }\end{array}$ & $\begin{array}{l}\$ 150 \mathrm{kF} \\
12 \text { to de- } \\
\text { velop plan }\end{array}$ & 0 & & 1Q & & $4 Q$ & & & & & & & & & & \\
\hline $\begin{array}{l}\text { - Document viable sources, options: biomass, geo-thermal, } \\
\text { gas-fired (nonrenewable), waste to energy, solar. } \\
\text { (COMPLETED) }\end{array}$ & $\begin{array}{l}\text { USACE } \\
\text { study }\end{array}$ & & 0 & & & & & & & & & & & & & & \\
\hline $\begin{array}{l}\text { - Conduct cost comparison and cost effectiveness. [Start 1Q11 } \\
\text { and ongoing.] }\end{array}$ & $\begin{array}{l}\text { USACE } \\
\text { study }\end{array}$ & & 0 & & & & & & & & & & & & & & \\
\hline $\begin{array}{l}\text { - Define technical feasibility and risk for viable sources. [Start } \\
1 Q 11 \text { and ongoing.] }\end{array}$ & $\begin{array}{l}\text { USACE } \\
\text { study }\end{array}$ & & 0 & & $2 Q$ & & & & & & & & & & & & \\
\hline - Create a timeline. (ON-GOING) & $\begin{array}{l}\text { DPW Ener- } \\
\text { gy \& MP }\end{array}$ & & 0 & & $2 Q$ & & & & & & & & & & & & \\
\hline - Develop recommendations for development and execution. & $\begin{array}{l}\text { DPW Ener- } \\
\text { gy \& MP }\end{array}$ & & 0 & & $\begin{array}{l}10- \\
3 Q\end{array}$ & & & & & & & & & & & & \\
\hline $\begin{array}{l}\text { - Conduct in-depth evaluation of approaches to power genera- } \\
\text { tion: on-site vs. off-site percentages, use of viable new technol- } \\
\text { ogies (fuel cells, micro grids, etc.), strategy for the next } 20 \text { years. }\end{array}$ & $\begin{array}{c}\text { DPW Ener- } \\
\text { gy \& MP }\end{array}$ & & 0 & & $4 Q$ & & & & & & & & & & & & \\
\hline $\begin{array}{l}\text { - Investigate load factor penalty and how to minimize cost. } \\
\text { Develop and implement load shedding and peak reduction } \\
\text { strategies. }\end{array}$ & $\begin{array}{l}\text { DPW Ener- } \\
\text { gy }\end{array}$ & & 0.1 & & 10 & & & & & & & & & & & & \\
\hline
\end{tabular}




\begin{tabular}{|c|c|c|c|c|c|c|c|c|c|c|c|c|c|c|c|c|c|}
\hline Actions for Objective 1.2 & $\begin{array}{l}\text { Lead / } \\
\text { Proponent }\end{array}$ & $\begin{array}{l}\text { Funding } \\
\text { Required }\end{array}$ & $\begin{array}{l}\text { Add'I } \\
\text { FTE } \\
\text { Required }\end{array}$ & $\begin{array}{l}\text { FY } \\
11\end{array}$ & $\begin{array}{l}\text { FY } \\
12\end{array}$ & $\begin{array}{l}\text { FY } \\
13\end{array}$ & $\begin{array}{l}\text { FY } \\
14\end{array}$ & $\begin{array}{l}\text { FY } \\
15\end{array}$ & $\begin{array}{l}\mathrm{FY} \\
16\end{array}$ & $\begin{array}{l}\text { FY } \\
17\end{array}$ & $\begin{array}{l}\text { FY } \\
18\end{array}$ & $\begin{array}{l}\mathrm{FY} \\
19\end{array}$ & $\begin{array}{l}\mathrm{FY} \\
20\end{array}$ & $\begin{array}{l}\text { FY } \\
25\end{array}$ & $\begin{array}{l}\mathrm{FY} \\
30\end{array}$ & $\begin{array}{l}\mathrm{FY} \\
35\end{array}$ & $\begin{array}{l}\mathrm{FY} \\
36\end{array}$ \\
\hline $\begin{array}{l}\text { - Evaluate purchase options from market to minimize cost and } \\
\text { maximize use of renewably generated power. Hire contract } \\
\text { expert support (PNEL, private). [Start 3Q11 and complete } \\
\text { 2Q12.] }\end{array}$ & $\begin{array}{l}\text { DPW Ener- } \\
\text { gy }\end{array}$ & $\$ 50 \mathrm{k}$ & $\begin{array}{l}0.3 \text { for } \\
\text { contract } \\
\text { oversight }\end{array}$ & & $2 Q$ & & & & & & & & & & & & \\
\hline $\begin{array}{l}\text { Establish contract to purchase power to be phased out as power } \\
\text { generation capability develops. Must have PPA in place by June } \\
2012\end{array}$ & $\begin{array}{l}\text { DPW Ener- } \\
\text { gy }\end{array}$ & & & & $3 Q$ & & & & & & & & & & & & \\
\hline $\begin{array}{l}\text { By } 1 \text { October 2012, monitor data provided at least daily and } \\
\text { electricity consumption measured hourly IAW EPAct } 2005 .\end{array}$ & DPW & $\$ 40 k$ & 0.3 & & $4 Q$ & & & & & & & & & & & & \\
\hline $\begin{array}{l}\text { Develop program of command accountability for energy and } \\
\text { water use (i.e., individual / unit usage comparison or bill pay- } \\
\text { ment). }\end{array}$ & G3 \& DPW & & 0.1 & & $2 Q$ & & & & & & & & & & & & \\
\hline $\begin{array}{l}\text { Incorporate energy savings into performance appraisals of man- } \\
\text { agers and staff who use installation facilities. }\end{array}$ & $\begin{array}{l}\text { Garrison } \\
\text { Cmdr. }\end{array}$ & & & & 10 & $3 Q$ & & & & & & & & & & & \\
\hline $\begin{array}{l}\text { Begin energy inspections and audits, } 25 \% \text { annually. Incorporate } \\
\text { into OIP. [Start } 4 Q 11 \text { and execute on a rotational basis to audit } \\
\text { entire installation every } 4 \text { years.] }\end{array}$ & & $\$ 200 k$ & 0.1 & & $4 Q$ & & & & & & & & & & & & \\
\hline $\begin{array}{l}\text { Identify and prioritize energy and water improvements execut- } \\
\text { ed in near term with limited impact to operations. }\end{array}$ & DPW & & & & $3 Q$ & & & & & & & & & & & & \\
\hline $\begin{array}{l}\text { Program for recommendations of annual operations and } \\
\text { maintenance cycle / improvement. }\end{array}$ & DPW & & & & $4 Q$ & $2 Q$ & & & & & & & & & & & \\
\hline $\begin{array}{l}\text { Develop and roll out an installation energy usage policy and Best } \\
\text { Energy Management (BEM) program to include those actions } \\
\text { below: }\end{array}$ & $\begin{array}{l}\text { DPW Ener- } \\
\text { gy }\end{array}$ & $\$ 100 k$ & 2.0 & & $4 Q$ & & & & & & & & & & & & \\
\hline $\begin{array}{l}\text { - Eliminate incandescent lights, inefficient appliances, personal } \\
\text { heaters and refrigerators, old pumps and motors. }\end{array}$ & & & & & 10 & & & & & & & & & & & & \\
\hline $\begin{array}{l}\text { - Establish uniform thermostat temperature set points within } \\
\text { Army guidelines. }\end{array}$ & & & & & $1 Q$ & & & & & & & & & & & & \\
\hline $\begin{array}{l}\text { - Disable systems with } 24 \text { / } 7 \text { circulating pumps (e.g., hot wa- } \\
\text { ter), consider timing controls (when hot water is not required } \\
\text { immediately) with high usage times. }\end{array}$ & & $\begin{array}{l}\$ 100 \mathrm{k} / \mathrm{yr} \text { in } \\
\mathrm{FY} 12-16\end{array}$ & & & 10 & & & & & & & & & & & & \\
\hline - Eliminate non-energy star appliances or replace oldest units. & & & & & 10 & & & & & & & & & & & & \\
\hline
\end{tabular}




\begin{tabular}{|c|c|c|c|c|c|c|c|c|c|c|c|c|c|c|c|c|c|}
\hline Actions for Objective 1.2 & $\begin{array}{l}\text { Lead / } \\
\text { Proponent }\end{array}$ & $\begin{array}{l}\text { Funding } \\
\text { Required }\end{array}$ & $\begin{array}{l}\text { Add'I } \\
\text { FTE } \\
\text { Required }\end{array}$ & $\begin{array}{l}\text { FY } \\
11\end{array}$ & $\begin{array}{l}\text { FY } \\
12\end{array}$ & $\begin{array}{l}\text { FY } \\
13\end{array}$ & $\begin{array}{l}\text { FY } \\
14\end{array}$ & $\begin{array}{l}\text { FY } \\
15\end{array}$ & $\begin{array}{l}\mathrm{FY} \\
16\end{array}$ & $\begin{array}{l}\mathrm{FY} \\
17\end{array}$ & $\begin{array}{l}\mathrm{FY} \\
18\end{array}$ & $\begin{array}{l}\mathrm{FY} \\
19\end{array}$ & $\begin{array}{l}\mathrm{FY} \\
20\end{array}$ & $\begin{array}{l}\mathrm{FY} \\
25\end{array}$ & $\begin{array}{l}\mathrm{FY} \\
30\end{array}$ & $\begin{array}{l}\mathrm{FY} \\
35\end{array}$ & $\begin{array}{l}\mathrm{FY} \\
36\end{array}$ \\
\hline — Remove non-compliant appliances. & & & & & 10 & & & & & & & & & & & & \\
\hline $\begin{array}{l}\text { - Develop incentives to motivate non-reimbursable facilities } \\
\text { (e.g., MWR) and tenants to conserve energy. }\end{array}$ & & & & & 10 & & & & & & & & & & & & \\
\hline $\begin{array}{l}\text { - Determine how to impact brigade and battalion command- } \\
\text { ers: appraisals, competitions, weekly briefings, etc. }\end{array}$ & & & & & 10 & & & & & & & & & & & & \\
\hline - Start new competition among facilities (per capita). & & & & & $\begin{array}{l}1 Q- \\
4 Q\end{array}$ & & & & & & & & & & & & \\
\hline $\begin{array}{l}\text { - Investigate other installations for potential incentive pro- } \\
\text { grams. (ON-GOING) }\end{array}$ & & & & & $4 Q$ & & & & & & & & & & & & \\
\hline $\begin{array}{l}\text { - Integrate best peak-shaving practices identified in Obj. } 1.2 \\
\text { into policy and BEM program to improve demand-side man- } \\
\text { agement. }\end{array}$ & & & & & 10 & & & & & & & & & & & & \\
\hline $\begin{array}{l}\text { - Conduct energy and water consumption assessments once } \\
\text { every } 4 \text { years for each facility. }\end{array}$ & & & & & 10 & & & & & & & & & & & & \\
\hline $\begin{array}{l}\text { - Use operation scheduling of generation vs. power procure- } \\
\text { ment to reduce cost. }\end{array}$ & & & & & & 10 & & & & & & & & & & & \\
\hline $\begin{array}{l}\text { - Develop training materials (in-person and on-line) for out- } \\
\text { reach and conduct training (e.g., safety days, institute energy } \\
\text { days). Conduct refresher training. Develop and provide quarter- } \\
\text { ly reports / newsletter. }\end{array}$ & & $\begin{array}{l}\$ 100 \mathrm{k} / \mathrm{yr} \text { in } \\
\text { support }\end{array}$ & & & $1 Q$ & & & & & & & & & & & & \\
\hline $\begin{array}{l}\text { - Properly scheduled programmable thermostats for all unoc- } \\
\text { cupied time. }\end{array}$ & $\begin{array}{l}\text { DPW Ener- } \\
\text { gy \& Ops/ } \\
\text { ESPC }\end{array}$ & $\$ 0$ & 0 & & & $3 Q$ & & & & & & & & & & & \\
\hline $\begin{array}{l}\text { - Improve reset schedules and economizer settings to reduce } \\
\text { re-heat requirements of outside air. }\end{array}$ & $\begin{array}{l}\text { DPW Ener- } \\
\text { gy \& Ops/ } \\
\text { ESPC }\end{array}$ & $\$ 0$ & 0 & & & 30 & & & & & & & & & & & \\
\hline $\begin{array}{l}\text { - Improve controls of chilled water set points and room supply } \\
\text { air temperature for AC energy use. }\end{array}$ & DPW & TBD & 0 & & & $3 Q$ & & & & & & & & & & & \\
\hline $\begin{array}{l}\text { - Assign responsibility for commissioning and decommission- } \\
\text { ing equipment to facility energy managers. }\end{array}$ & $\begin{array}{l}\text { Garrison } \\
\text { Cmdr. }\end{array}$ & TBD & TBD & & & 30 & & & & & & & & & & & \\
\hline $\begin{array}{l}\text { - Facility energy managers responsible for establishing O\&M } \\
\text { plans for measuring, verifying, and reporting energy and water } \\
\text { savings, per EISA } 432 \text {. }\end{array}$ & DPW & TBD & TBD & & & 30 & & & & & & & & & & & \\
\hline - Perform reimbursable evaluation (MWR, laundry, etc.). & $\begin{array}{l}\text { DPW Ener- } \\
\text { gy/ Utilities }\end{array}$ & $\$ 0$ & 0.1 & & & 30 & & & & & & & & & & & \\
\hline
\end{tabular}




\begin{tabular}{|c|c|c|c|c|c|c|c|c|c|c|c|c|c|c|c|c|c|}
\hline Actions for Objective 1.2 & $\begin{array}{l}\text { Lead / } \\
\text { Proponent }\end{array}$ & $\begin{array}{l}\text { Funding } \\
\text { Required }\end{array}$ & $\begin{array}{l}\text { Add'I } \\
\text { FTE } \\
\text { Required }\end{array}$ & $\begin{array}{l}\text { FY } \\
11\end{array}$ & $\begin{array}{l}\text { FY } \\
12\end{array}$ & $\begin{array}{l}\mathrm{FY} \\
13\end{array}$ & $\begin{array}{l}\text { FY } \\
14\end{array}$ & $\begin{array}{l}\text { FY } \\
15\end{array}$ & $\begin{array}{l}\text { FY } \\
16\end{array}$ & $\begin{array}{l}\text { FY } \\
17\end{array}$ & $\begin{array}{l}\text { FY } \\
18\end{array}$ & $\begin{array}{l}\text { FY } \\
19\end{array}$ & $\begin{array}{l}\mathrm{FY} \\
20\end{array}$ & $\begin{array}{l}\mathrm{FY} \\
25\end{array}$ & $\begin{array}{l}\mathrm{FY} \\
\mathbf{3 0}\end{array}$ & $\begin{array}{l}\text { FY } \\
35\end{array}$ & $\begin{array}{l}\text { FY } \\
36\end{array}$ \\
\hline $\begin{array}{l}\text { Conduct baseline assessments of water usage to identify facili- } \\
\text { ties that need retrofits. }\end{array}$ & DPW & & & & $1 Q$ & 10 & & & & & & & & & & & \\
\hline $\begin{array}{l}\text { Develop comprehensive potable water and sanitary sewer im- } \\
\text { provement programs. Update existing infrastructure to reduce } \\
\text { water losses and ensure water to support current and future } \\
\text { missions and development. [1Q11 and ongoing.] }\end{array}$ & DPW & $\begin{array}{l}\text { Need CLS } \\
\text { funds for } \\
\text { sewer \& } \\
\text { water } \\
\text { systems }\end{array}$ & $\begin{array}{c}\text { Fund } \\
\text { yearly } \\
\text { per } \\
\text { study - } \\
\text { maint. } \\
\text { upgrades }\end{array}$ & & $2 Q$ & & & & & & & & & & & & \\
\hline Sewer, reduce in-flow (document benefits) and ensure capacity. & DPW & & & & $2 Q$ & $2 Q$ & & & & & & & & & & & \\
\hline $\begin{array}{l}\text { Comprehensive water / sewer study. [Awarding contract FY10, } \\
\text { expected completion in FY12.] }\end{array}$ & DPW & & & & $3 Q$ & & & & & & & & & & & & \\
\hline $\begin{array}{l}\text { Sewer, reduce in-flow (document benefits) and ensure capacity. } \\
\text { [Ongoing through } 3 Q 12 .]\end{array}$ & DPW & & & & $3 Q$ & & & & & & & & & & & & \\
\hline $\begin{array}{l}\text { Comprehensive water / sewer study [awarding contract FY10, } \\
\text { expected completion in FY12.] }\end{array}$ & DPW & & & & $3 Q$ & & & & & & & & & & & & \\
\hline $\begin{array}{l}\text { Program for recommendations of annual operations and } \\
\text { maintenance cycle / improvement. }\end{array}$ & DPW & & & & $4 Q$ & $2 Q$ & & & & & & & & & & & \\
\hline
\end{tabular}


Goal 1 Description: Fort Leonard Wood will, in the next 25 years, transform into an installation with an efficient network of high-performance, sustainable, and resilient infrastructure systems enabling mission assurance and mission expansion.

Objective 1.3: By 2030, develop new and modernize existing facilities to perform at net-zero with respect to energy, water, and waste, while providing a high quality of life and adaptable work environment.

Description: Change the way we build and renovate buildings to ensure that all future infrastructures are sustainable to the greatest extent technologically feasible, cost effective to maintain and operate, and eventually meet Army net-zero waste, energy, and water goals.

Lead/Proponent: DPW

\section{FTE Required for Obj. 1.3: 2.0 FTEs in 4Q FY11-FY36}

Funding Required for Obj. 1.3: \$200k in FY11, \$331k in FY12 and \$25k/yr in FY13-36. Annual update conference begins in FY12, actions will identify additional investments to upgrade infrastructure. These additional investments will be integrated into subsequent POM budgets.

\begin{tabular}{|c|c|c|c|c|c|c|c|c|c|c|c|c|c|c|c|c|c|}
\hline Actions for Objective 1.3 & $\begin{array}{c}\text { Lead / } \\
\text { Proponent }\end{array}$ & $\begin{array}{l}\text { Funding } \\
\text { Required }\end{array}$ & $\begin{array}{l}\text { Add'I } \\
\text { FTE } \\
\text { Required }\end{array}$ & $\begin{array}{l}\text { FY } \\
11\end{array}$ & $\begin{array}{l}\text { FY } \\
12\end{array}$ & $\begin{array}{l}\mathrm{FY} \\
13\end{array}$ & $\begin{array}{l}\text { FY } \\
14\end{array}$ & $\begin{array}{l}\text { FY } \\
15\end{array}$ & $\begin{array}{l}\mathrm{FY} \\
16\end{array}$ & $\begin{array}{l}\text { FY } \\
17\end{array}$ & $\begin{array}{l}\mathrm{FY} \\
18\end{array}$ & $\begin{array}{l}\text { FY } \\
19\end{array}$ & $\begin{array}{l}\mathrm{FY} \\
20\end{array}$ & $\begin{array}{l}\text { FY } \\
25\end{array}$ & $\begin{array}{l}\text { FY } \\
30\end{array}$ & $\begin{array}{l}\text { FY } \\
35\end{array}$ & $\begin{array}{l}\text { FY } \\
36\end{array}$ \\
\hline $\begin{array}{l}\text { Establish a sustainability coordinator in PAIO to track progress, } \\
\text { provide support, and promote sustainability throughout the } \\
\text { installation. In addition, hire and designate a sustainable design } \\
\text { engineer to work with the sustainability coordinator with respect } \\
\text { to sustainable development. Engineer will support actions identi- } \\
\text { fied under objectives } 1.1 \text { and } 1.3 \text {. (ON-GOING) }\end{array}$ & $\begin{array}{c}\text { PAIO \& } \\
\text { DPW }\end{array}$ & $\$ 0$ & 2.0 & & $2 Q$ & & & & & & & & & & & & \\
\hline $\begin{array}{l}\text { Revise IDG and develop Sustainable Design Strategy to guide all } \\
\text { future construction and renovation to meet sustainability goals. } \\
\text { Start with USACE Zero-footprint Design Study started 2Q11. Use } \\
\text { IDG to integrate sustainability into infrastructure usage and de- } \\
\text { velopment decision-making. }\end{array}$ & $\begin{array}{c}\text { DPW Eng. \& } \\
\text { MP }\end{array}$ & $\$ 200 k$ & $\begin{array}{c}\text { Sust. } \\
\text { Design } \\
\text { Engineer }\end{array}$ & & $2 Q$ & $2 Q$ & & & & & & & & & & & \\
\hline $\begin{array}{l}\text { Mandate that all local new construction, restoration, and mod- } \\
\text { ernization projects (SRM and OMA) meet IDG direction to inte- } \\
\text { grate sustainable design into all infrastructure by } 2030 \text {. }\end{array}$ & $\mathrm{DPW} / \mathrm{GC}$ & $\$ 0$ & & & $3 Q$ & & & & & & & & & & & & \\
\hline
\end{tabular}




\begin{tabular}{|c|c|c|c|c|c|c|c|c|c|c|c|c|c|c|c|c|c|}
\hline Actions for Objective 1.3 & $\begin{array}{l}\text { Lead / } \\
\text { Proponent }\end{array}$ & $\begin{array}{l}\text { Funding } \\
\text { Required }\end{array}$ & $\begin{array}{l}\text { Add'I } \\
\text { FTE } \\
\text { Required }\end{array}$ & $\begin{array}{l}\text { FY } \\
11\end{array}$ & $\begin{array}{l}\text { FY } \\
12\end{array}$ & $\begin{array}{l}\text { FY } \\
13\end{array}$ & $\begin{array}{l}\text { FY } \\
14\end{array}$ & $\begin{array}{l}\text { FY } \\
15\end{array}$ & $\begin{array}{l}\text { FY } \\
16\end{array}$ & $\begin{array}{l}\text { FY } \\
17\end{array}$ & $\begin{array}{l}\text { FY } \\
18\end{array}$ & $\begin{array}{l}\text { FY } \\
19\end{array}$ & $\begin{array}{l}\text { FY } \\
20\end{array}$ & $\begin{array}{l}\text { FY } \\
25\end{array}$ & $\begin{array}{l}\text { FY } \\
30\end{array}$ & $\begin{array}{l}\text { FY } \\
35\end{array}$ & $\begin{array}{l}\text { FY } \\
36\end{array}$ \\
\hline $\begin{array}{l}\text { In support of the IDG revision, participate in a net-zero design } \\
\text { demonstration including selecting and training staff in building } \\
\text { re-commissioning techniques and approaches and evidence- } \\
\text { based design. Use webinars and live training. [Start 2Q11 USACE } \\
\text { Net Zero Design Project.] (COMPLETED) }\end{array}$ & DPW & $\$ 0$ & & $\begin{array}{l}2 Q- \\
4 Q\end{array}$ & & & & & & & & & & & & & \\
\hline $\begin{array}{l}\text { Using the results of inventory of inadequate buildings and repur- } \\
\text { posing evaluation (Objective 1.1), develop roadmap to high- } \\
\text { performance sustainable development and construction. }\end{array}$ & DPW ED & $\begin{array}{l}\text { IMCOM/ } \\
\text { Corps } \\
\text { Support }\end{array}$ & $\begin{array}{l}\text { Sust. } \\
\text { Design } \\
\text { Engineer }\end{array}$ & & $3 Q$ & & & & & & & & & & & & \\
\hline Train DPW Engineering/Design/Master Planning Staff: & DPW & & & & $\begin{array}{l}1 Q- \\
2 Q\end{array}$ & & & & & & & & & & & & \\
\hline $\begin{array}{l}\text { - LEED orientation for all FLW PDC staff. Support those seeking } \\
\text { to become LEED Green Associates. }\end{array}$ & $\begin{array}{l}\text { DPW/USACE } \\
\text { ERDC-CERL }\end{array}$ & $\$ 20 k$ & & & $\begin{array}{l}10 \\
\text { Start } \\
\& \\
\text { End }\end{array}$ & & & & & & & & & & & & \\
\hline $\begin{array}{l}\text { - For interested/appropriate staff, provide LEED Advanced } \\
\text { training. Support their efforts to become LEED Accredited Pro- } \\
\text { fessionals. }\end{array}$ & $\begin{array}{l}\text { DPW/USACE } \\
\text { ERDC-CERL }\end{array}$ & $\begin{array}{l}\text { \$1k Engi- } \\
\text { neer }\end{array}$ & & & 1Q & & & & & & & & & & & & \\
\hline $\begin{array}{l}\text { - Provide LEED Prospect Class for the application of LEED in } \\
\text { military construction. }\end{array}$ & $\begin{array}{l}\text { DPW/USACE } \\
\text { ERDC-CERL }\end{array}$ & $\$ 10 k$ & & & $3 Q$ & & & & & & & & & & & & \\
\hline $\begin{array}{l}\text { - Integrate LEED into IDPs of the appropriate staff (see Goal } 5 \\
\text { on workforce development). }\end{array}$ & DPW & & & & $1 Q$ & & & & & & & & & & & & \\
\hline $\begin{array}{l}\text { Develop standards and policy to ensure major replacement of } \\
\text { installed equipment, renovation or expansion of existing space } \\
\text { using the most energy-efficient designs, systems, equipment and } \\
\text { control effective lifecycle cost per EISA, para } 434 \text {. }\end{array}$ & DPW & & $\begin{array}{l}\text { Sust. } \\
\text { Design } \\
\text { Engineer }\end{array}$ & & $3 Q$ & & & & & & & & & & & & \\
\hline $\begin{array}{l}\text { Hire interns to support technical evaluations to ensure preferen- } \\
\text { tial selection of energy-efficient materials, systems, and designs } \\
\text { when available and cost neutral or beneficial (for major systems). } \\
\text { [First interns in place - initial work supports development of the } \\
\text { installation standard 3Q11.] }\end{array}$ & DPW & $\$ 150 k$ & $\begin{array}{l}\text { Sust. } \\
\text { Design } \\
\text { Engineer }\end{array}$ & & $2 Q$ & & & & & & & & & & & & \\
\hline
\end{tabular}




\begin{tabular}{|c|c|c|c|c|c|c|c|c|c|c|c|c|c|c|c|c|c|}
\hline Actions for Objective 1.3 & $\begin{array}{c}\text { Lead / } \\
\text { Proponent }\end{array}$ & $\begin{array}{l}\text { Funding } \\
\text { Required }\end{array}$ & $\begin{array}{l}\text { Add'I } \\
\text { FTE } \\
\text { Required }\end{array}$ & $\begin{array}{l}\text { FY } \\
11\end{array}$ & $\begin{array}{l}\mathrm{FY} \\
12\end{array}$ & $\begin{array}{l}\text { FY } \\
13\end{array}$ & $\begin{array}{l}\text { FY } \\
14\end{array}$ & $\begin{array}{l}\text { FY } \\
15\end{array}$ & $\begin{array}{l}\mathrm{FY} \\
16\end{array}$ & $\begin{array}{l}\text { FY } \\
17\end{array}$ & $\begin{array}{l}\text { FY } \\
18\end{array}$ & $\begin{array}{l}\text { FY } \\
19\end{array}$ & $\begin{array}{l}\mathrm{FY} \\
20\end{array}$ & $\begin{array}{l}F Y \\
25\end{array}$ & $\begin{array}{l}\text { FY } \\
30\end{array}$ & $\begin{array}{l}\text { FY } \\
35\end{array}$ & $\begin{array}{l}\mathrm{FY} \\
36\end{array}$ \\
\hline $\begin{array}{l}\text { Conduct quarterly sustainability functional champions. Reassess } \\
\text { periodically after two years. Sustainability coordinator will sup- } \\
\text { port quarterly meetings to provide the Command Group (CG, } \\
\text { DCG, GC and DGC) with progress reports from team leaders. } \\
\text { (ON-GOING - contracted support in place by Nov 2011) }\end{array}$ & PAIO & $\$ 0$ & $\begin{array}{l}\text { Sust. } \\
\text { Coor. } \\
\text { PAIO }\end{array}$ & & $2 Q$ & $2 Q$ & & & & & & & & & & & \\
\hline $\begin{array}{l}\text { Based upon the results of the facilities evaluation to identify } \\
\text { inadequate infrastructure (under Obj 1.1), develop and execute a } \\
\text { capital investment strategy for the systematic improvement of } \\
\text { existing buildings that will not be demolished. }\end{array}$ & DPW & $\begin{array}{l}\$ 125 \mathrm{k} \text { to } \\
\text { develop } \\
\text { plan. } \\
\text { Execution } \\
\text { program- } \\
\text { med into } \\
\text { future } \\
\text { budgets. }\end{array}$ & 0 & & $3 Q$ & & & & & & & & & & & & \\
\hline $\begin{array}{l}\text { By } 2030 \text {, require all contractors to increase their diversion rate of } \\
\text { construction/demolition waste from landfilling from } 50 \% \text { (cur- } \\
\text { rent) to } 100 \% \text { through salvage, resell, reuse, and recycling. To do } \\
\text { this, identify local partners who might support construction con- } \\
\text { tractors (especially with deconstruction). Provide examples of } \\
\text { successes from other installations. }\end{array}$ & DPW/DOC & $\$ 0$ & 0 & & & 10 & & & & & & & & & & & \\
\hline $\begin{array}{l}\text { Internal annual sustainability conference, plan review, and sus- } \\
\text { tainability report card on FLW progress. }\end{array}$ & PAIO & $\begin{array}{l}\$ 25 \mathrm{k} / \mathrm{yr} \\
\text { in FY12- } \\
36\end{array}$ & $\begin{array}{l}\text { Sust. } \\
\text { Coor. } \\
\text { PAIO }\end{array}$ & & $4 Q$ & & & & & & & & & & & & \\
\hline
\end{tabular}


Goal 2 Description: Improve mission services by communication, collaboration and coordination internally and externally (tenants, other service providers, surrounding communities). Enhance capabilities to rapidly adapt to emerging technologies and changing force structure and doctrine to ensure sustainability. Reduced logistics footprint through facility and operational efficiencies.

Objective 2.1: Reduced footprint and optimized food service support.

Description: An integrated, Installation-wide initiative to determine and implement an optimal food service support system for FLW that reduces operating costs and wastes, while providing efficient and high-quality food services.

\section{Lead/Proponent: DOL}

\section{FTE Required for Obj.2.1: 0}

Funding Required for Obj. 2.1: \$0

\begin{tabular}{|c|c|c|c|c|c|c|c|c|c|c|c|c|c|c|c|c|c|}
\hline Actions for Objective 2.1 & $\begin{array}{l}\text { Lead/ } \\
\text { Proponent }\end{array}$ & $\begin{array}{l}\text { Funding } \\
\text { Required }\end{array}$ & $\begin{array}{l}\text { Add'I } \\
\text { FTE } \\
\text { Required }\end{array}$ & $\begin{array}{l}\text { FY } \\
11\end{array}$ & $\begin{array}{l}\mathrm{FY} \\
12\end{array}$ & $\begin{array}{l}\text { FY } \\
13\end{array}$ & $\begin{array}{l}\text { FY } \\
14\end{array}$ & $\begin{array}{l}\text { FY } \\
15\end{array}$ & $\begin{array}{l}\text { FY } \\
16\end{array}$ & $\begin{array}{l}\text { FY } \\
17\end{array}$ & $\begin{array}{l}\text { FY } \\
18\end{array}$ & $\begin{array}{l}\text { FY } \\
19\end{array}$ & $\begin{array}{l}\mathrm{FY} \\
20\end{array}$ & $\begin{array}{l}\text { FY } \\
25\end{array}$ & $\begin{array}{l}\mathrm{FY} \\
30\end{array}$ & $\begin{array}{l}\text { FY } \\
35\end{array}$ & $\begin{array}{l}\mathrm{FY} \\
36\end{array}$ \\
\hline Recycle products from subsistence packaging. & DOL/LGFS & $\$ 0$ & & & 10 & & & & & & & & & & & & \\
\hline Identify location/opportunities to reduce waste. & DOL/LGFS & $\mathrm{N} / \mathrm{A}$ & & & $2 Q$ & & & & & & & & & & & & \\
\hline Verify requirements. & & N/A & & & $2 Q$ & & & & & & & & & & & & \\
\hline $\begin{array}{l}\text { Identify community team members. [Started and completed } \\
\text { 2Q11.] }\end{array}$ & DOL/LGFS & & & $\begin{array}{l}\text { End } \\
2 Q\end{array}$ & & & & & & & & & & & & & \\
\hline Study current manning levels with workload. (COMPLETED) & $\begin{array}{l}\text { DHR, with } \\
\text { DRM. }\end{array}$ & & & $\begin{array}{l}1 Q- \\
4 Q\end{array}$ & & & & & & & & & & & & & \\
\hline $\begin{array}{l}\text { Change DFAC current designs projected for construction to } \\
\text { better facilitate current and future needs. (COMPLETED) } \\
\text { Opened two-story DFAC to increase capacity while reducing } \\
\text { number of separate lines - closed two older DFACs }\end{array}$ & $\begin{array}{l}\text { USACE, } \\
\text { with DPW, } \\
\text { DOL. }\end{array}$ & & & $1 \mathrm{Q}$ & $4 Q$ & & & & & & & & & & & & \\
\hline $\begin{array}{l}\text { Change style of food service in some facilities to a carry-out } \\
\text { facility and/or Central Field Feed Kitchen. }\end{array}$ & DOL/LGFS & & & & 30 & & & & & & & & & & & & \\
\hline
\end{tabular}

Total FTE Required for Goal 2: 1200 hours total (approx. 0.7 FTE) spread across FY11-FY19. Some objectives for FTEs are "TBD." Total Funding Required for Goal 2: TBD 
Goal 2 Description: Improve mission services by communication, collaboration and coordination internally and externally (tenants, other service providers, surrounding communities). Enhance capabilities to rapidly adapt to emerging technologies and changing force structure and doctrine to ensure sustainability. Reduced logistics footprint through facility and operational efficiencies.

Objective 2.2: Efficiency through establishing an enterprise facility for logistical support.

Description: Create and establish a "state of the art" facility to better provide cost- and energy-efficient services to the customers and also provide more timeIy services without the need for unnecessary movement or delay. Create a "one stop" logistics facility which takes in all concerns of the

FORSCOM/TRADOC/AMC/IMCOM commanders. SR2-2: Develop programs that help synchronize resources and requirements across the key ARFORGEN processes - Man, Equip, Train with a focus on installation support.

\section{Lead/Proponent: DOL}

FTE Required for Obj. 2.2: 1200 hours total (approx. 0.7 FTE) spread across FY11-FY19.

Funding Required for Obj. 2.2: TBD

\begin{tabular}{|c|c|c|c|c|c|c|c|c|c|c|c|c|c|c|c|c|c|}
\hline Actions for Objective $\mathbf{2 . 2}$ & $\begin{array}{l}\text { Lead / } \\
\text { Proponent }\end{array}$ & $\begin{array}{l}\text { Funding } \\
\text { Required }\end{array}$ & $\begin{array}{l}\text { Add'I FTE } \\
\text { Required }\end{array}$ & $\begin{array}{l}\text { FY } \\
11\end{array}$ & $\begin{array}{l}\text { FY } \\
12\end{array}$ & $\begin{array}{l}\text { FY } \\
13\end{array}$ & $\begin{array}{l}\text { FY } \\
14\end{array}$ & $\begin{array}{l}\text { FY } \\
15\end{array}$ & $\begin{array}{l}\text { FY } \\
16\end{array}$ & $\begin{array}{l}\text { FY } \\
17\end{array}$ & $\begin{array}{l}\mathrm{FY} \\
18\end{array}$ & $\begin{array}{l}\text { FY } \\
19\end{array}$ & $\begin{array}{l}\text { FY } \\
20\end{array}$ & FY 25 & $\begin{array}{l}\text { FY } \\
30\end{array}$ & $\begin{array}{l}\mathrm{FY} \\
35\end{array}$ & $\begin{array}{l}\text { FY } \\
36\end{array}$ \\
\hline $\begin{array}{l}\text { Visit or coordinate with similar installations to capture } \\
\text { benchmark and best practices. Evaluate Fort Future de- } \\
\text { sign considerations/lesson learned. }\end{array}$ & $\begin{array}{l}\text { DOL, coord } \\
\text { with RM }\end{array}$ & $\begin{array}{l}\text { TDY cost } \\
\text { (TBD) }\end{array}$ & $400 \mathrm{hrs}$ & & $2 Q$ & & & & & & & & & & & & \\
\hline $\begin{array}{l}\text { Identify all of the logistical Requirement/Square foot- } \\
\text { age/Resources. Evaluate existing facilities. [Started } \\
\text { 1Q11.] }\end{array}$ & $\begin{array}{l}\text { DOL, coord } \\
\text { with } \\
\text { DPTM, } \\
\text { DPW }\end{array}$ & $\$ 0$ & 800 hrs & & $3 Q$ & & & & & & & & & & & & \\
\hline $\begin{array}{l}\text { Engage with Master Planning Process to begin scoping } \\
\text { new training center as part of long-term development } \\
\text { plan. }\end{array}$ & & & & & $2 Q$ & $2 Q$ & & & & & & & & & & & \\
\hline $\begin{array}{l}\text { Identify outside stakeholders (AMC/DLA, Community, } \\
\text { etc.) and coordinate with all stakeholders on their input } \\
\text { to logistical requirements. [Started 1Q11.] }\end{array}$ & DOL & $\$ 0$ & & & $2 Q$ & $2 Q$ & & & & & & & & & & & \\
\hline Develop Concept Plan for approval. & $\begin{array}{l}\text { DOL, coord } \\
\text { with PAIO }\end{array}$ & & & & & $\begin{array}{c}10 \\
- \\
4 Q\end{array}$ & & & & & & & & & & & \\
\hline Design \& locate facilities. & $\begin{array}{l}\text { DOL with } \\
\text { DPW }\end{array}$ & $\begin{array}{l}\text { Design } \\
\text { costs }\end{array}$ & & & & $2 Q$ & & & & & & & & & & & \\
\hline $\begin{array}{l}\text { Deployment of cost centers against IMCOM/AMC stand- } \\
\text { ards. }\end{array}$ & $\begin{array}{l}\text { DOL with } \\
\text { DRM }\end{array}$ & & & & & & & & & & & & & & & & \\
\hline
\end{tabular}




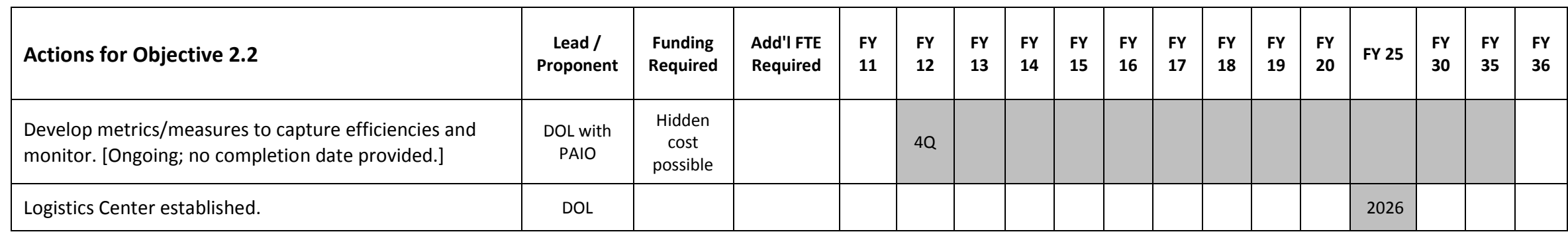


Goal 2 Description: Improve mission services by communication, collaboration and coordination internally and externally (tenants, other service providers, surrounding communities).

Enhance capabilities to rapidly adapt to emerging technologies and changing force structure and doctrine to ensure sustainability. Reduced logistics footprint through facility and operational efficiencies.

Objective 2.3: Upgraded deployment support services and infrastructure (rail heads, rail, staging areas, airfields, etc.).

Description: Expand and upgrade the existing (or non-existent) air and rail facilities to provide cost-efficient and timely rapid deployment service support. Priorities include identifying locations for various tasks, equipment needed to complete the tasks and identifying funding resources to complete the requirement.

Support IMCOM IR1-2: Strategic Mobility Infrastructure (SMI) that fully enables ARFORGEN deployment/redeployment cycles.

Lead/Proponent: DOL

\section{FTE Required for Obj.2.3: TBD}

Funding Required for Obj. 2.3: TBD

\begin{tabular}{|c|c|c|c|c|c|c|c|c|c|c|c|c|c|c|c|c|c|}
\hline Actions for Objective 2.3 & $\begin{array}{l}\text { Lead / } \\
\text { Proponent }\end{array}$ & $\begin{array}{l}\text { Funding } \\
\text { Required }\end{array}$ & $\begin{array}{l}\text { Add'I FTE } \\
\text { Required }\end{array}$ & $\begin{array}{l}\text { FY } \\
11\end{array}$ & $\begin{array}{l}\mathrm{FY} \\
12\end{array}$ & $\begin{array}{l}\text { FY } \\
13\end{array}$ & $\begin{array}{l}\text { FY } \\
14\end{array}$ & $\begin{array}{l}\text { FY } \\
15\end{array}$ & $\begin{array}{l}\text { FY } \\
16\end{array}$ & $\begin{array}{l}\text { FY } \\
17\end{array}$ & $\begin{array}{l}\text { FY } \\
18\end{array}$ & $\begin{array}{l}\text { FY } \\
19\end{array}$ & $\begin{array}{l}\mathrm{FY} \\
20\end{array}$ & $\begin{array}{l}\text { FY } \\
25\end{array}$ & $\begin{array}{l}\mathrm{FY} \\
30\end{array}$ & $\begin{array}{l}\text { FY } \\
35\end{array}$ & $\begin{array}{l}\text { FY } \\
36\end{array}$ \\
\hline $\begin{array}{l}\text { Evaluate deployment scenarios to create deployment } \\
\text { plan/identify infrastructure needs to optimize deployment capac- } \\
\text { ity/capability. }\end{array}$ & & & & & $4 Q$ & & & & & & & & & & & & \\
\hline $\begin{array}{l}\text { Identify what the requirement is and then evaluate it (e.g., facili- } \\
\text { ties, equip, location). (COMPLETED) }\end{array}$ & $\begin{array}{l}\text { DOL, with } \\
\text { 4th MEB } \\
\text { FLW }\end{array}$ & & & & & & & & & & & & & & & & \\
\hline Coordinate with community stakeholders. [Started 2Q11.] & $\begin{array}{l}\text { DOL, with } \\
\text { 4th MEB } \\
\text { FLW }\end{array}$ & & & $2 Q$ & $2 Q$ & & & & & & & & & & & & \\
\hline Develop a concept plan for future requirements. Initiated 4QFY11 & $\begin{array}{l}\text { DOL, with } \\
\text { 4th MEB } \\
\text { FLW }\end{array}$ & & $\begin{array}{l}\text { TBD by } \\
\text { evaluating } \\
\text { require- } \\
\text { ments }\end{array}$ & $4 Q$ & $4 Q$ & & & & & & & & & & & & \\
\hline $\begin{array}{l}\text { HOLD THIS ACTION FOR DEVELOPMENT IN NEXT UPDATE. SR3-1: } \\
\text { Develop the ability to quantify and communicate installation re- } \\
\text { quirements in order to synchronize IAW with the ARFORGEN } \\
\text { Cycle. [Started } 1 Q 11 \text { and ongoing.] }\end{array}$ & $\begin{array}{c}\text { DOL, with } \\
\text { FORSCOM } \\
\text { HQ }\end{array}$ & & & & & & & & & & & & & & & & \\
\hline
\end{tabular}


Table 33. Objective 2.4 Action Plan.

Goal 2 Description: Improve mission services by communication, collaboration and coordination internally and externally (tenants, other service providers, surrounding communities). Enhance capabilities to rapidly adapt to emerging technologies and changing force structure and doctrine to ensure sustainability. Reduced logistics footprint through facility and operational efficiencies.

Objective 2.4: Efficiency through establishing an enterprise system for service members' in- and out-processing.

Description: Create and establish an automated enterprise system to provide a centralized in- and out-processing service to the customers and also provide a more timely service without the need for unnecessary movement or delay.

\section{Lead/Proponent: DHR}

FTE Required for Obj.2.4: TBD

Funding Required for Obj. 2.4: TBD

\begin{tabular}{|c|c|c|c|c|c|c|c|c|c|c|c|c|c|c|c|c|c|}
\hline Actions for Objective 2.4 & $\begin{array}{c}\text { Lead / } \\
\text { Proponent }\end{array}$ & $\begin{array}{l}\text { Funding } \\
\text { Required }\end{array}$ & $\begin{array}{l}\text { Add'I FTE } \\
\text { Required }\end{array}$ & $\begin{array}{l}\mathrm{FY} \\
11\end{array}$ & $\begin{array}{l}\mathrm{FY} \\
12\end{array}$ & $\begin{array}{l}\mathrm{FY} \\
13\end{array}$ & $\begin{array}{l}\mathrm{FY} \\
14\end{array}$ & $\begin{array}{l}F Y \\
15\end{array}$ & $\begin{array}{l}\mathrm{FY} \\
16\end{array}$ & $\begin{array}{l}\mathrm{FY} \\
17\end{array}$ & $\begin{array}{l}\mathrm{FY} \\
18\end{array}$ & $\begin{array}{l}\mathrm{FY} \\
19\end{array}$ & $\begin{array}{l}\mathrm{FY} \\
20\end{array}$ & $\begin{array}{l}\mathrm{FY} \\
25\end{array}$ & $\begin{array}{l}\mathrm{FY} \\
\mathbf{3 0}\end{array}$ & $\begin{array}{l}\mathrm{FY} \\
35\end{array}$ & $\begin{array}{l}F Y \\
36\end{array}$ \\
\hline $\begin{array}{l}\text { Determine current levels/effectiveness of automation } \\
\text { (ON-GOING as part of Lean Six Sigma) }\end{array}$ & $\begin{array}{l}\text { DHR, sup- } \\
\text { port by G1, } \\
\text { ITRO, NEC }\end{array}$ & $\$ 0$ & 0 & & $\begin{array}{l}2 Q- \\
3 Q\end{array}$ & & & & & & & & & & & & \\
\hline $\begin{array}{l}\text { Develop baseline information for in / out processing } \\
\text { requirements and procedures for all types/categories of } \\
\text { service members (PCS, TDY, Foreign Students, initial en- } \\
\text { try, etc.). (COMPLETED) }\end{array}$ & $\begin{array}{l}\text { DHR with all } \\
\text { mission } \\
\text { services/ } \\
\text { orgs/ direc- } \\
\text { torates }\end{array}$ & $\$ 0$ & 0 & & 10 & 10 & & & & & & & & & & & \\
\hline $\begin{array}{l}\text { Develop / implement methods to improve in / out pro- } \\
\text { cessing though an automated enterprise system. May } \\
\text { include sharing best practices, improving/expanding } \\
\text { automation and/or new facilities as needed. Will develop } \\
\text { specific projects/actions after plan developed / ap- } \\
\text { proved. Should include evaluating use of CAC card pro- } \\
\text { gramming capabilities. (ON-GOING) }\end{array}$ & $\begin{array}{l}\text { DHR with } \\
\text { NEC, all orgs } \\
\text { conducting } \\
\text { in/out pro- } \\
\text { cessing }\end{array}$ & & $\begin{array}{l}\text { May re- } \\
\text { quire new } \\
\text { FTEs to } \\
\text { staff } \\
\text { (TBD) }\end{array}$ & & & $2 Q$ & & & & & & & & & & & \\
\hline $\begin{array}{l}\text { Develop system / procedures for one-stop accurate in- } \\
\text { formation on real-time supported population (perma- } \\
\text { nent party and training / students, to include all services, } \\
\text { reserve, guard, OS units). (ON-GOING) }\end{array}$ & $\begin{array}{l}\text { DHR sup- } \\
\text { ported by } \\
\text { NEC }\end{array}$ & & $\begin{array}{l}\text { May re- } \\
\text { quire new } \\
\text { FTEs to } \\
\text { staff } \\
\text { (TBD) } \\
\end{array}$ & & $\begin{array}{l}1 Q- \\
4 Q\end{array}$ & & & & & & & & & & & & \\
\hline
\end{tabular}

. 
Goal 2 Description: Improve mission services by communication, collaboration and coordination internally and externally (tenants, other service providers, surrounding communities). Enhance capabilities to rapidly adapt to emerging technologies and changing

force structure and doctrine to ensure sustainability. Reduced logistics footprint through

facility and operational efficiencies.

Objective 2.5: A Non-Tactical Vehicle fleet that provides optimum mission and customer support at minimum cost, while taking full advantage of emerging technologies to minimize negative impacts on the environment.

NOTE: Objective 2.5 will be incorporated/evaluated in a Cost-Culture Study by the Garrison Commander. Actions and projects will be developed based on results of that study.

Description: Includes GSA fleet, MWR, commercial material handling equipment, and any non-deployable Army owned or leased self-propelled equipment.

\section{Lead/Proponent: DOL}

\section{FTE Required for Obj.2.5: TBD}

Funding Required for Obj. 2.5: TBD

\begin{tabular}{|c|c|c|c|c|c|c|c|c|c|c|c|c|c|c|c|c|}
\hline Actions for Objective 2.5 & $\begin{array}{l}\text { Lead / } \\
\text { Proponent }\end{array}$ & $\begin{array}{l}\text { Funding } \\
\text { Required }\end{array}$ & $\begin{array}{c}\text { Add'I } \\
\text { FTE } \\
\text { Required }\end{array}$ & FY 12 & $\begin{array}{l}\text { FY } \\
13\end{array}$ & $\begin{array}{l}\text { FY } \\
14\end{array}$ & $\begin{array}{l}\text { FY } \\
15\end{array}$ & $\begin{array}{l}\text { FY } \\
16\end{array}$ & $\begin{array}{l}\text { FY } \\
17\end{array}$ & $\begin{array}{l}\text { FY } \\
18\end{array}$ & $\begin{array}{l}\mathrm{FY} \\
19\end{array}$ & $\begin{array}{l}\mathrm{FY} \\
20\end{array}$ & $\begin{array}{l}\text { FY } \\
25\end{array}$ & $\begin{array}{l}\text { FY } \\
30\end{array}$ & $\begin{array}{l}\mathrm{FY} \\
35\end{array}$ & $\begin{array}{l}\text { FY } \\
36\end{array}$ \\
\hline Reduce fleet size by $46 \%$ by end of $\mathrm{FY} 12$ & & & & $4 Q$ & & & & & & & & & & & & \\
\hline $\begin{array}{l}\text { Increase the level of alternative/renewable fuel } \\
\text { equipment. }\end{array}$ & & & & & & & & & & & & & & & & \\
\hline Increase alternative fuel consumption. & & & & & & & & & & & & & & & & \\
\hline $\begin{array}{l}\text { Decrease petroleum fuel consumption. } \\
\text { - Troops transport system (mass transit) }\end{array}$ & & & & & & & & & & & & & & & & \\
\hline
\end{tabular}


Table 35. Objective 3.1 Action Plan.

Goal 3 Description: FLW has an effective and enduring strategic communications program that empowers and engages the installation with the greater community and stakeholders to support mutual missions and efforts, and enhance jobs to make FLW the station of choice.

Objective 3.1: Actively participate in the planning and execution of regional, community, and economic development programs that enhance the QOL for the greater FLW community.

Description: Coordinated regional activities that define community direction, establishing regional development patterns, identifying and pursuing economic development that will improve quality of life in the region, and establishing forums where community stakeholders, including FLW, can work together to accomplish beneficial goals and objectives including:

- Economics

- Education

- Health Care and Social Services

- Housing

- Land Use

- Public Safety

- Transportation

Lead/Proponent: PAIO, State of Missouri DED, and Communities.

FTE Required for Obj.3.1: 0 FTE

Funding Required for Obj. 3.1: \$0

\begin{tabular}{|c|c|c|c|c|c|c|c|c|c|c|c|c|c|c|c|c|c|}
\hline \multicolumn{18}{|l|}{$\begin{array}{l}\text { Actively participate in regional initiatives to estab- } \\
\text { lish full-service medical facilities for soldiers and } \\
\text { the local population (including expanding VA ser- } \\
\text { vices, cancer treatment, and dialysis centers) } \\
\text { through the following activities: }\end{array}$} \\
\hline $\begin{array}{l}\text { In conjunction with SJA, establish enduring policies that } \\
\text { define permissible roles/activities for participating in this } \\
\text { forum. }\end{array}$ & PAIO & $\$ 0$ & 0 & $3 Q$ & $2 Q$ & & & & & & & & & & & & \\
\hline $\begin{array}{l}\text { Hospital Commander engages local community on re- } \\
\text { gional health services and needs. (INITIATED) }\end{array}$ & $\begin{array}{l}\text { Hospital } \\
\text { Cmdr. }\end{array}$ & $\$ 0$ & 0 & & & & & & & & & & & & & & \\
\hline Evaluate community incentives (e.g., state, regional). & PAIO & $\$ 0$ & 0 & & $2 Q$ & $2 Q$ & & & & & & & & & & & \\
\hline
\end{tabular}




\begin{tabular}{|c|c|c|c|c|c|c|c|c|c|c|c|c|c|c|c|c|c|}
\hline Actions for Objective 3.1 & $\begin{array}{l}\text { Lead / Pro- } \\
\text { ponent }\end{array}$ & $\begin{array}{l}\text { Funding } \\
\text { Required }\end{array}$ & $\begin{array}{l}\text { Add'I FTE } \\
\text { Required }\end{array}$ & $\begin{array}{l}\text { FY } \\
11\end{array}$ & FY 12 & $\begin{array}{l}\text { FY } \\
13\end{array}$ & $\begin{array}{l}\text { FY } \\
14\end{array}$ & $\begin{array}{l}\text { FY } \\
15\end{array}$ & $\begin{array}{l}\mathrm{FY} \\
16\end{array}$ & $\begin{array}{l}\text { FY } \\
17\end{array}$ & $\begin{array}{l}\text { FY } \\
18\end{array}$ & $\begin{array}{l}\text { FY } \\
19\end{array}$ & $\begin{array}{l}\mathrm{FY} \\
20\end{array}$ & $\begin{array}{l}\text { FY } \\
25\end{array}$ & $\begin{array}{l}\mathrm{FY} \\
30\end{array}$ & $\begin{array}{l}\mathrm{FY} \\
35\end{array}$ & $\begin{array}{l}\text { FY } \\
36\end{array}$ \\
\hline $\begin{array}{l}\text { Precipitate/establish a community medical fo- } \\
\text { rum/committee (i.e., Gen (ret) Dewitt, Cox, Phelps, Mer- } \\
\text { cy, Pulaski Public Health Board, committee under minis- } \\
\text { terial alliance, planning commissions, PCGA). Document } \\
\text { the problem; develop/describe path forward; document } \\
\text { FLW "point of view"; and develop path forward. }\end{array}$ & PAIO & $\$ 0$ & 0 & & & $2 Q$ & & & & & & & & & & & \\
\hline $\begin{array}{l}\text { Evaluate approaches/best practices at similarly posi- } \\
\text { tioned installations in the Army system. }\end{array}$ & PAIO & $\$ 0$ & 0 & & & $2 Q$ & & & & & & & & & & & \\
\hline \multicolumn{17}{|l|}{$\begin{array}{l}\text { Support and participate in efforts to increase use, } \\
\text { size, and scope of regional airport to improve ac- } \\
\text { cessibility through the following activities: }\end{array}$} & \\
\hline $\begin{array}{l}\text { Explore/create local travel policies to endorse the use of } \\
\text { the airport. }\end{array}$ & PAIO & $\$ 0$ & & & $\begin{array}{l}1 Q- \\
3 Q\end{array}$ & & & & & & & & & & & & \\
\hline $\begin{array}{l}\text { Engage with government travel (waiting for the numbers } \\
\text { back on whether or not it might be profitable to fly into } \\
\text { another hub and then direct to FLW). }\end{array}$ & PAIO & $\$ 0$ & $\begin{array}{l}.1 \text { Sustain- } \\
\text { ability Coor- } \\
\text { dinator }\end{array}$ & & $3 Q$ & 10 & & & & & & & & & & & \\
\hline $\begin{array}{l}\text { Compile data set for AP use (commercial, commuter, and } \\
\text { business). }\end{array}$ & PAIO & $\$ 0$ & & & & $\begin{array}{c}10 \\
- \\
4 Q\end{array}$ & & & & & & & & & & & \\
\hline Coordinate for AAFES services at AP (food court). & PAIO & $\$ 0$ & & & $3 Q$ & 10 & & & & & & & & & & & \\
\hline Explore charter aviation support through travel policies. & PAIO & $\$ 0$ & & & $3 Q$ & 30 & & & & & & & & & & & \\
\hline $\begin{array}{l}\text { Get buy-in from Tech Park tenants and contractors' use } \\
\text { of AP. }\end{array}$ & UM Liaison & $\$ 0$ & & & $4 Q$ & & & & & & & & & & & & \\
\hline Participate in the off-post airport development team. & PAIO & $\$ 0$ & & & $4 Q$ & & & & & & & & & & & & \\
\hline \multicolumn{17}{|l|}{$\begin{array}{l}\text { Develop a strategic regional land-use plan through } \\
\text { the following activities }\end{array}$} & \\
\hline Initiate JLUS Evaluation (INITIATED) & $\begin{array}{l}\text { Meramec } \\
\quad \text { RPC }\end{array}$ & $\begin{array}{l}\text { OEA } \\
\text { funds for } \\
\text { JLUS }\end{array}$ & 0 & & & & & & & & & & & & & & \\
\hline Identify FLW proponents for JLUS.(COMPLETED) & PAIO & $\$ 0$ & 0 & & & & & & & & & & & & & & \\
\hline Develop JLUS initial communication plan (timelines). & STRATCOM & $\$ 0$ & 0 & $4 Q$ & $3 Q$ & & & & & & & & & & & & \\
\hline Hold town hall meetings to present FLW usage/needs. & PAIO & $\$ 0$ & 0 & & $2 Q$ & 30 & & & & & & & & & & & \\
\hline Update and implement strategic communication plan. & STRATCOM & $\$ 0$ & 0 & & 10 & 30 & & & & & & & & & & & \\
\hline Complete JLUS. & $\begin{array}{l}\text { Meramec } \\
\text { RPC }\end{array}$ & $\$ 0$ & 0 & & & $2 Q$ & & & & & & & & & & & \\
\hline
\end{tabular}




\begin{tabular}{|c|c|c|c|c|c|c|c|c|c|c|c|c|c|c|c|c|c|}
\hline Actions for Objective 3.1 & $\begin{array}{l}\text { Lead / Pro- } \\
\text { ponent }\end{array}$ & $\begin{array}{l}\text { Funding } \\
\text { Required }\end{array}$ & $\begin{array}{l}\text { Add'I FTE } \\
\text { Required }\end{array}$ & $\begin{array}{l}\text { FY } \\
11\end{array}$ & FY 12 & $\begin{array}{l}\mathrm{FY} \\
13\end{array}$ & $\begin{array}{l}\mathrm{FY} \\
14\end{array}$ & $\begin{array}{l}\mathrm{FY} \\
15\end{array}$ & $\begin{array}{l}\mathrm{FY} \\
16\end{array}$ & $\begin{array}{l}\mathrm{FY} \\
17\end{array}$ & $\begin{array}{l}\mathrm{FY} \\
18\end{array}$ & $\begin{array}{l}\text { FY } \\
19\end{array}$ & $\begin{array}{l}\mathrm{FY} \\
20\end{array}$ & $\begin{array}{l}\text { FY } \\
25\end{array}$ & $\begin{array}{l}\mathrm{FY} \\
30\end{array}$ & $\begin{array}{l}\mathrm{FY} \\
35\end{array}$ & $\begin{array}{l}\mathrm{FY} \\
36\end{array}$ \\
\hline & & & & & & $4 Q$ & & & & & & & & & & & \\
\hline \multicolumn{18}{|l|}{ Additional Activities: } \\
\hline $\begin{array}{l}\text { Finding/approval by the CG that FLW can participate in } \\
\text { planning for economic development: Cases (Forts Carson, } \\
\text { Bragg, and Hood) from others; Opinion from higher-level } \\
\text { SJA; Opinion from SJA. }\end{array}$ & PAIO & $\$ 0$ & 0 & & $\begin{array}{c}2 Q- \\
4 Q\end{array}$ & & & & & & & & & & & & \\
\hline $\begin{array}{l}\text { Appoint team to work on economic development (indi- } \\
\text { viduals who will participate). }\end{array}$ & PAIO & $\$ 0$ & 0 & $4 Q$ & 10 & & & & & & & & & & & & \\
\hline $\begin{array}{l}\text { Engage with State of Missouri DED to conduct economic } \\
\text { development forum on FLW. }\end{array}$ & PAIO & $\$ 0$ & 0 & $4 Q$ & 10 & & & & & & & & & & & & \\
\hline $\begin{array}{l}\text { Participate in regional transportation planning and rec- } \\
\text { ognize existing community transportation infrastructure } \\
\text { as per EO13514\$2(f)(i)--Membership on Meramec Re- } \\
\text { gional Planning Commission (Trans. Advisory Committee). }\end{array}$ & PAIO, DPW & $\$ 0$ & 0 & $3 Q$ & 10 & & & & & & & & & & & & \\
\hline
\end{tabular}


Goal 3 Description: FLW has an effective and enduring strategic communications program

that empowers and engages the installation with the greater community and stakeholders to

support mutual missions and efforts, and enhance jobs to make FLW the station of choice.

Objective 3.2: Leverage enduring partnerships with academia, industry, and government to help solve defense-related science and technology challenges; establish FLW as a thriving national security center; and promote regional, sustainable economic development.

Description: Use partnerships effectively through policy and actions to enhance mission, support regional economic development, and support mission requirements that pose unique challenges to the Installation. Solidify partnerships with:

- The University of Missouri Technical Park

- The Leonard Wood Institute

- Missouri University of Science and Technology (Missouri S\&T)

- Park Service

Lead/Proponent: MSCoE, JIIM-IA. Completed in FY20.

FTE Required for Obj.3.2: 0.5 FTE in STRATCOM in 3Q FY11-20.

Funding Required for Obj. 3.2: $\$ 300 \mathrm{k} / \mathrm{yr}$ in FY11-20.

\begin{tabular}{|c|c|c|c|c|c|c|c|c|c|c|c|c|c|c|c|c|c|}
\hline Actions for Objective 3.2 & $\begin{array}{c}\text { Lead / } \\
\text { Proponent }\end{array}$ & $\begin{array}{l}\text { Funding } \\
\text { Required }\end{array}$ & $\begin{array}{l}\text { Add'I } \\
\text { FTE } \\
\text { Required }\end{array}$ & $\begin{array}{l}\text { FY } \\
11\end{array}$ & $\begin{array}{l}\mathrm{FY} \\
12\end{array}$ & $\begin{array}{l}\text { FY } \\
13\end{array}$ & $\begin{array}{l}\mathrm{FY} \\
14\end{array}$ & $\begin{array}{l}\text { FY } \\
15\end{array}$ & $\begin{array}{l}\text { FY } \\
16\end{array}$ & $\begin{array}{l}\text { FY } \\
17\end{array}$ & $\begin{array}{l}\text { FY } \\
18\end{array}$ & $\begin{array}{l}\text { FY } \\
19\end{array}$ & $\begin{array}{l}\mathrm{FY} \\
20\end{array}$ & $\begin{array}{l}\text { FY } \\
25\end{array}$ & $\begin{array}{l}\text { FY } \\
30\end{array}$ & $\begin{array}{l}\mathrm{FY} \\
35\end{array}$ & $\begin{array}{l}\mathrm{FY} \\
36\end{array}$ \\
\hline $\begin{array}{l}\text { Participate in the forum that LWI is currently working to } \\
\text { establish in which installation tenants present their needs } \\
\text { to help provide information regarding potential partner- } \\
\text { ships that can identify/obtain funding. }\end{array}$ & JIIM-IA & $\begin{array}{c}\$ 300 k \\
\text { annually }\end{array}$ & 0 & $3 Q$ & & & & & & & & & & & & & \\
\hline $\begin{array}{l}\text { Use cases from other installations who have done this to } \\
\text { justify FLW participation. Define approach, revisit for } \\
\text { more cases.(COMPLETED) }\end{array}$ & JIIM-IA & $\$ 0$ & 0 & \multicolumn{4}{|c|}{ Completed 4Q FY10 } & & & & & & & & & & \\
\hline $\begin{array}{l}\text { Explore approach to form partnerships through CRADAs } \\
\text { between LWI, ARL, and researchers to support FLW needs, } \\
\text { leading to a defense technology cluster. }\end{array}$ & JIIM-IA & $\$ 0$ & 0 & $3 Q$ & & & & & & & & & & & & & \\
\hline $\begin{array}{l}\text { Expand marketing of FLW to potential partners (e.g., pri- } \\
\text { vate, public, state government): }\end{array}$ & $\begin{array}{l}\text { STRATCOM } \\
\text { and PAIO }\end{array}$ & $\$ 0$ & 0.5 & $3 Q$ & & & & & & & & & & & & & \\
\hline $\begin{array}{l}\text { - Acquire recommendations from Univ MO Columbia } \\
\text { (partial list of targets and approach). }\end{array}$ & & & & $3 Q$ & & & & & & & & & & & & & \\
\hline
\end{tabular}




\begin{tabular}{|c|c|c|c|c|c|c|c|c|c|c|c|c|c|c|c|c|c|}
\hline Actions for Objective 3.2 & $\begin{array}{l}\text { Lead / } \\
\text { Proponent }\end{array}$ & $\begin{array}{l}\text { Funding } \\
\text { Required }\end{array}$ & $\begin{array}{l}\text { Add'I } \\
\text { FTE } \\
\text { Required }\end{array}$ & $\begin{array}{l}\mathrm{FY} \\
11\end{array}$ & $\begin{array}{l}\mathrm{FY} \\
12\end{array}$ & $\begin{array}{l}\mathrm{FY} \\
13\end{array}$ & $\begin{array}{l}\mathrm{FY} \\
14\end{array}$ & $\begin{array}{l}\text { FY } \\
15\end{array}$ & $\begin{array}{l}\mathrm{FY} \\
16\end{array}$ & $\begin{array}{l}\mathrm{FY} \\
17\end{array}$ & $\begin{array}{l}\mathrm{FY} \\
18\end{array}$ & $\begin{array}{l}\mathrm{FY} \\
19\end{array}$ & $\begin{array}{l}\mathrm{FY} \\
20\end{array}$ & $\begin{array}{l}\mathrm{FY} \\
25\end{array}$ & $\begin{array}{l}\mathrm{FY} \\
30\end{array}$ & $\begin{array}{l}\text { FY } \\
35\end{array}$ & $\begin{array}{l}\mathrm{FY} \\
36\end{array}$ \\
\hline $\begin{array}{l}\text { - Identify national research partners and develop a na- } \\
\text { tional marketing message. }\end{array}$ & & & & $3 Q$ & & & & & & & & & & & & & \\
\hline $\begin{array}{l}\text { - Leverage FLW support with community marketing for } \\
\text { regional economic development. }\end{array}$ & & & & $3 Q$ & & & & & & & & & & & & & \\
\hline - Conduct Regional Science and Technology Forums. & & & & 30 & & & & & & & & & & & & & \\
\hline
\end{tabular}


Table 37. Objective 3.3 Action Plan.

Goal 3 Description: FLW has an effective and enduring strategic communications program

that empowers and engages the installation with the greater community and stakeholders

to support mutual missions and efforts, and enhance jobs to make FLW the station of choice.

Objective 3.3: FLW has consistent, positive, national media coverage that promotes FLW commands, missions, and expertise.

Description: Active communication that illustrates the importance of FLW to the Army, the State of Missouri, regional partners, and the local community.

Lead/Proponent: PAO. Completed FY20.

\section{FTE Required for Obj.3.3: 1.0 FTE in STRATCOM in 3Q FY11 - 1Q FY12 and 1.0 FTE in PAO in 1Q FY12-14.}

Funding Required for Obj. 3.3: If the 2.0 FTEs not obtained, then $\$ 150 \mathrm{k} / \mathrm{yr}$ in FY11-12 for STRATCOM and another $\$ 150 \mathrm{k} / \mathrm{yr}$ in FY12-14 for PAO for contracted services.

\begin{tabular}{|c|c|c|c|c|c|c|c|c|c|c|c|c|c|c|c|c|c|}
\hline Actions for Objective $\mathbf{3 . 3}$ & $\begin{array}{l}\text { Lead / } \\
\text { Proponent }\end{array}$ & $\begin{array}{l}\text { Funding } \\
\text { Required }\end{array}$ & $\begin{array}{l}\text { Add'I FTE } \\
\text { Required }\end{array}$ & $\begin{array}{l}\mathrm{FY} \\
11\end{array}$ & $\begin{array}{l}\mathrm{FY} \\
12\end{array}$ & $\begin{array}{l}\mathrm{FY} \\
13\end{array}$ & $\begin{array}{l}\mathrm{FY} \\
14\end{array}$ & $\begin{array}{l}\mathrm{FY} \\
15\end{array}$ & $\begin{array}{l}\mathrm{FY} \\
16\end{array}$ & $\begin{array}{l}\mathrm{FY} \\
17\end{array}$ & $\begin{array}{l}\mathrm{FY} \\
18\end{array}$ & $\begin{array}{l}\mathrm{FY} \\
19\end{array}$ & $\begin{array}{l}\mathrm{FY} \\
20\end{array}$ & $\begin{array}{l}\mathrm{FY} \\
25\end{array}$ & $\begin{array}{l}\mathrm{FY} \\
30\end{array}$ & $\begin{array}{l}\mathrm{FY} \\
35\end{array}$ & $\begin{array}{l}\mathrm{FY} \\
36\end{array}$ \\
\hline \multicolumn{18}{|l|}{$\begin{array}{l}\text { Develop an accessible Strategic Communications } \\
\text { Plan that supports MSCoE, IMCOM, and TRADOC } \\
\text { strategic plans. (COMPLETED) }\end{array}$} \\
\hline $\begin{array}{l}\text { Determine how the plan will be made available, possibly } \\
\text { through the Regional Commerce Growth Association } \\
\text { (RCGA) website. }\end{array}$ & $\begin{array}{l}\text { STRATCOM, } \\
\text { G6 }\end{array}$ & $\$ 0$ & 0 & & $4 Q$ & & & & & & & & & & & & \\
\hline $\begin{array}{l}\text { Develop a process to define the content (what's in and } \\
\text { out?). Content will be timely and include internal mes- } \\
\text { sages and public messages. The plan will determine posi- } \\
\text { tions and policies on such topics as: Medical support, } \\
\text { Housing, Access to installation and Energy. }\end{array}$ & $\begin{array}{l}\text { STRATCOM, } \\
\text { PAO }\end{array}$ & $\$ 0$ & $\begin{array}{l}0.5 \text { in } \\
\text { addition to } \\
\text { STRATCOM }\end{array}$ & & $4 Q$ & & & & & & & & & & & & \\
\hline $\begin{array}{l}\text { Establish information distribution mechanisms (e.g., } \\
\text { websites, forums, etc.) as per IMCOM CP LW2-1. }\end{array}$ & $\begin{array}{l}\text { STRATCOM, } \\
\text { G6 }\end{array}$ & $\$ 0$ & $\begin{array}{l}\text { Staff time } \\
\text { to main- } \\
\text { tain info }\end{array}$ & & $4 Q$ & & & & & & & & & & & & \\
\hline $\begin{array}{l}\text { Establish a systems approach for determining what in- } \\
\text { formation goes out, obtaining approval through the Sr. } \\
\text { Commander and frequency/approach to distribution. } \\
\text { (COMPLETED) }\end{array}$ & STRATCOM & $\$ 0$ & 0 & & & & & & & & & & & & & & \\
\hline $\begin{array}{l}\text { Continually identify the information communities want } \\
\text { considered for distribution. }\end{array}$ & PAO & $\$ 0$ & 0 & & $2 Q$ & & & & & & & & & & & & \\
\hline $\begin{array}{l}\text { Identify routine information that should be made availa- } \\
\text { ble automatically (e.g., population, construction pro- } \\
\text { jects). Periodically review and update this information. }\end{array}$ & $\begin{array}{l}\text { STRATCOM, } \\
\text { PAO }\end{array}$ & $\$ 0$ & 0 & & $4 Q$ & & & & & & & & & & & & \\
\hline
\end{tabular}




\begin{tabular}{|c|c|c|c|c|c|c|c|c|c|c|c|c|c|c|c|c|c|}
\hline Actions for Objective $\mathbf{3 . 3}$ & $\begin{array}{l}\text { Lead / } \\
\text { Proponent }\end{array}$ & $\begin{array}{l}\text { Funding } \\
\text { Required }\end{array}$ & $\begin{array}{l}\text { Add'I FTE } \\
\text { Required }\end{array}$ & $\begin{array}{l}\mathrm{FY} \\
11\end{array}$ & $\begin{array}{l}\text { FY } \\
12\end{array}$ & $\begin{array}{l}\mathrm{FY} \\
13\end{array}$ & $\begin{array}{l}\text { FY } \\
14\end{array}$ & $\begin{array}{l}\text { FY } \\
15\end{array}$ & $\begin{array}{l}\mathrm{FY} \\
16\end{array}$ & $\begin{array}{l}\mathrm{FY} \\
17\end{array}$ & $\begin{array}{l}\mathrm{FY} \\
18\end{array}$ & $\begin{array}{l}\mathrm{FY} \\
19\end{array}$ & $\begin{array}{l}\text { FY } \\
20\end{array}$ & $\begin{array}{l}\text { FY } \\
25\end{array}$ & $\begin{array}{l}\text { FY } \\
30\end{array}$ & $\begin{array}{l}\text { FY } \\
35\end{array}$ & $\begin{array}{l}\text { FY } \\
36\end{array}$ \\
\hline Periodically assess delivery method effectiveness. & $\begin{array}{l}\text { PAO, } \\
\text { STRATCOM }\end{array}$ & $\$ 0$ & 0 & & $4 Q$ & $4 Q$ & & & & & & & & & & & \\
\hline $\begin{array}{l}\text { Staff a broadcast person (specialist to produce videos) or } \\
\text { contract for service / student hires. }\end{array}$ & PAO & $\begin{array}{c}\$ 150 k \\
\text { annually }\end{array}$ & 1.0 & & 1Q & & & & & & & & & & & & \\
\hline $\begin{array}{l}\text { Develop a director capable of using alternate media } \\
\text { (YouTube, Core) to get the message out. Staff or contract } \\
\text { out. }\end{array}$ & STRATCOM & $\begin{array}{c}\$ 150 k \\
\text { annually }\end{array}$ & 1.0 & & $2 Q$ & $2 Q$ & & & & & & & & & & & \\
\hline Develop 20 story lines per year. & $\begin{array}{l}\text { STRATCOM } \\
\quad \& \text { PAO }\end{array}$ & \multicolumn{2}{|c|}{$\begin{array}{l}\text { Part of funds or staff } \\
\text { identified above }\end{array}$} & & $\begin{array}{l}1 Q- \\
4 Q\end{array}$ & & & & & & & & & & & & \\
\hline Market storylines done by producer. & PAO & \multicolumn{2}{|c|}{$\begin{array}{l}\text { Part of funds or staff } \\
\text { identified above }\end{array}$} & & & & 1Q & & & & & & & & & & \\
\hline $\begin{array}{l}\text { Engage Sr. Army PAO leaders with our senior leaders to } \\
\text { market successes (need materials produced by first four } \\
\text { steps to market). }\end{array}$ & PAO & \multicolumn{2}{|c|}{$\begin{array}{l}\text { Part of funds or staff } \\
\text { identified above }\end{array}$} & & $2 Q$ & & & & & & & & & & & & \\
\hline $\begin{array}{l}\text { Use technology to support collaboration and communica- } \\
\text { tion (use materials produced under step 2). }\end{array}$ & PAO & \multicolumn{2}{|c|}{$\begin{array}{l}\text { Part of funds or staff } \\
\text { identified above }\end{array}$} & & $2 Q$ & & & & & & & & & & & & \\
\hline
\end{tabular}


Goal 3 Description: FLW has an effective and enduring strategic communications program

that empowers and engages the installation with the greater community and stakeholders

to support mutual missions and efforts, and enhance jobs to make FLW the station of choice.

Objective 3.4: A regional partnership forum that promotes outreach to local communities, inspiring community support. Community partnerships support the FLW mission and enhance stakeholder interaction (including Installation visits).

Description: Senior leadership participates in making presentations to additional regional partnerships and activities as a means for strengthening ties with the surrounding community.

\section{Lead/Proponent: PAO. Establish by FY12.}

\section{FTE Required for Obj.3.4: 0 FTE}

Funding Required for Obj. 3.4: \$0

\begin{tabular}{|c|c|c|c|c|c|c|c|c|c|c|c|c|c|c|c|c|c|}
\hline Actions for Objective 3.4 & $\begin{array}{l}\text { Lead / } \\
\text { Proponent }\end{array}$ & $\begin{array}{l}\text { Funding } \\
\text { Required }\end{array}$ & $\begin{array}{l}\text { Add'I FTE } \\
\text { Required }\end{array}$ & $\begin{array}{l}\mathrm{FY} \\
11\end{array}$ & $\begin{array}{l}\text { FY } \\
12\end{array}$ & $\begin{array}{l}\text { FY } \\
13\end{array}$ & $\begin{array}{l}\text { FY } \\
14\end{array}$ & $\begin{array}{l}\text { FY } \\
15\end{array}$ & $\begin{array}{l}\text { FY } \\
16\end{array}$ & $\begin{array}{l}\text { FY } \\
17\end{array}$ & $\begin{array}{l}\text { FY } \\
18\end{array}$ & $\begin{array}{l}\text { FY } \\
19\end{array}$ & $\begin{array}{l}\mathrm{FY} \\
20\end{array}$ & $\begin{array}{l}\text { FY } \\
25\end{array}$ & $\begin{array}{l}\text { FY } \\
30\end{array}$ & $\begin{array}{l}\text { FY } \\
35\end{array}$ & $\begin{array}{l}\mathrm{FY} \\
36\end{array}$ \\
\hline $\begin{array}{l}\text { Establish a schedule for open forum discussion to promote } \\
\text { FLW and key topics (Speaker's Bureau) as per SW4-3. }\end{array}$ & $\begin{array}{l}\text { Chamber } \\
\text { Director }\end{array}$ & $\$ 0$ & 0 & & $4 Q$ & & & & & & & & & & & & \\
\hline $\begin{array}{l}\text { Engage with: Lake - Support the Fort; Rolla - Phelps for the } \\
\text { Fort; Lebanon - Friends of the Fort; Waynesville-St. Robert - } \\
\text { Committee of } 50 \text {. }\end{array}$ & PAO & $\$ 0$ & 0 & & $4 Q$ & & & & & & & & & & & & \\
\hline Approval by Command Group for quarterly presentation. & PAO & $\$ 0$ & 0 & & $4 Q$ & & & & & & & & & & & & \\
\hline Coordinate calendar with SGS for first event. & SGS, PAO & $\$ 0$ & 0 & & $4 Q$ & & & & & & & & & & & & \\
\hline
\end{tabular}


Table 39. Objective 3.5 Action Plan.

Goal 3 Description: FLW has an effective and enduring strategic communications program

that empowers and engages the installation with the greater community and stakeholders

to support mutual missions and efforts, and enhance jobs to make FLW the station of

choice.

Objective 3.5: Ozark Regional Sustainability Initiative.

Description: Establish an initiative to encourage and support sustainable development to the benefit of all within the region.

Lead/Proponent: PAIO. Completed FY14.

FTE Required for Obj.3.5: 0.2 FTE in 4Q FY11 - 2Q FY12 (Sustainability Coordinator - PAIO)

Funding Required for Obj. 3.5: $\$ 100 \mathrm{k} / \mathrm{yr}$ for FY12 and FY13

\begin{tabular}{|c|c|c|c|c|c|c|c|c|c|c|c|c|c|c|c|c|c|}
\hline Actions for Objective 3.5 & $\begin{array}{l}\text { Lead / } \\
\text { Proponent }\end{array}$ & $\begin{array}{l}\text { Funding } \\
\text { Required }\end{array}$ & $\begin{array}{c}\text { Add'I } \\
\text { FTE } \\
\text { Required }\end{array}$ & $\begin{array}{l}\mathrm{FY} \\
11\end{array}$ & $\begin{array}{l}\mathrm{FY} \\
12\end{array}$ & $\begin{array}{l}\mathrm{FY} \\
13\end{array}$ & $\begin{array}{l}\mathrm{FY} \\
14\end{array}$ & $\begin{array}{l}\mathrm{FY} \\
15\end{array}$ & $\begin{array}{l}\mathrm{FY} \\
16\end{array}$ & $\begin{array}{l}\text { FY } \\
17\end{array}$ & $\begin{array}{l}\mathrm{FY} \\
18\end{array}$ & $\begin{array}{l}\text { FY } \\
19\end{array}$ & $\begin{array}{l}\mathrm{FY} \\
20\end{array}$ & $\begin{array}{l}\mathrm{FY} \\
25\end{array}$ & $\begin{array}{l}\mathrm{FY} \\
\mathbf{3 0}\end{array}$ & $\begin{array}{l}\mathrm{FY} \\
35\end{array}$ & $\begin{array}{l}\mathrm{FY} \\
36\end{array}$ \\
\hline Staff a sustainability person at FLW.(COMPLETED) & PAIO & $\$ 0$ & 0.2 & & $2 Q$ & & & & & & & & & & & & \\
\hline $\begin{array}{l}\text { Coordinate with communities to identify a non-profit that will } \\
\text { take a leadership role.(COMPLETED) }\end{array}$ & LWI & \begin{tabular}{|c}
$\$ 100 k / y r$ \\
for FY12 \\
$\&$ FY13
\end{tabular} & 0 & & 10 & & & & & & & & & & & & \\
\hline $\begin{array}{l}\text { Develop a scope of activities and approach for the organization. } \\
\text { (COMPLETED) }\end{array}$ & LWI & $\$ 0$ & 0 & & $2 Q$ & & & & & & & & & & & & \\
\hline $\begin{array}{l}\text { Identify and pursue funding: State and Federal Grants (matching } \\
\text { funds); DUSDA - I\&E ESOH; OEA; EPA. }\end{array}$ & LWI & $\$ 0$ & 0 & & 10 & & & & & & & & & & & & \\
\hline $\begin{array}{l}\text { Start the process: Convene meetings, create MOU, sign MOU. } \\
\text { (INITIATED) }\end{array}$ & LWI & $\$ 0$ & 0 & & $2 Q$ & & & & & & & & & & & & \\
\hline
\end{tabular}


Goal 4 Description: Service Members, Families, and Civilians are provided opportunities, programs and facilities enabling them to become resilient in mind, body, and spirit. Provide holistic, consolidated and multi-functional (educational, physical fitness, recreational/leisure and religious) services. Ensure all services are based on an ongoing needs assessment.

Objective 4.1: Develop an Installation Resiliency Campus.

Description: A health and wellness resiliency campus for comprehensive Soldier and family wellness (e.g., Chaplain, ACS, Behavioral Health, ASAP, and Suicide Prevention resources).

Lead/Proponent: DFMWR and Community Health Promotion Council.

FTE Required for Obj.4.1: 60 hours total in 2Q-4Q FY11 and 0.1 FTE in 4Q FY12-13 for support planning, additional FTE to support Campus is TBD. Funding Required for Obj. 4.1: TBD

\begin{tabular}{|c|c|c|c|c|c|c|c|c|c|c|c|c|c|c|c|c|c|}
\hline Actions for Objective 4.1 & $\begin{array}{l}\text { Lead / } \\
\text { Proponent }\end{array}$ & $\begin{array}{l}\text { Funding } \\
\text { Required }\end{array}$ & $\begin{array}{l}\text { Add'I FTE } \\
\text { Required }\end{array}$ & FY 11 & $\begin{array}{l}\text { FY } \\
12\end{array}$ & $\begin{array}{l}\mathrm{FY} \\
13\end{array}$ & $\begin{array}{l}\mathrm{FY} \\
14\end{array}$ & $\begin{array}{l}\mathrm{FY} \\
15\end{array}$ & $\begin{array}{l}\mathrm{FY} \\
16\end{array}$ & $\begin{array}{l}\text { FY } \\
17\end{array}$ & $\begin{array}{l}\text { FY } \\
18\end{array}$ & $\begin{array}{l}\mathrm{FY} \\
19\end{array}$ & $\begin{array}{l}\mathrm{FY} \\
20\end{array}$ & $\begin{array}{l}\mathrm{FY} \\
25\end{array}$ & $\begin{array}{l}\mathrm{FY} \\
30\end{array}$ & $\begin{array}{l}\mathrm{FY} \\
35\end{array}$ & $\begin{array}{l}\mathrm{FY} \\
36\end{array}$ \\
\hline $\begin{array}{l}\text { Determine which functions and programs will be part of the } \\
\text { campus. (Initiated 2Q11.) }\end{array}$ & $\begin{array}{l}\text { Community } \\
\text { Health } \\
\text { Promotion } \\
\text { Council }\end{array}$ & $\$ 0$ & $60 \mathrm{hrs}$ & $2 \mathrm{Q}$ & 30 & & & & & & & & & & & & \\
\hline $\begin{array}{l}\text { Proponents for selected functions and programs provide } \\
\text { facility requirements to DPW. }\end{array}$ & $\begin{array}{l}\text { Community } \\
\text { Health } \\
\text { Promotion } \\
\text { Council }\end{array}$ & $\$ 0$ & & & $4 Q$ & & & & & & & & & & & & \\
\hline $\begin{array}{l}\text { Detailed analysis of space requirements by DPW to deter- } \\
\text { mine allowance for new facilities and/or re-allocation of } \\
\text { existing space. }\end{array}$ & DPW & $\$ 0$ & & & $\begin{array}{c}2 Q- \\
4 Q\end{array}$ & & & & & & & & & & & & \\
\hline $\begin{array}{l}\text { Integrate resiliency campus into Master Plan update. Devel- } \\
\text { op project design package and DD Form } 1391 \text { (or appropri- } \\
\text { ate documents if not through MCA). }\end{array}$ & DPW & $\$ 0$ & 0.1 & & $4 Q$ & & & & & & & & & & & & \\
\hline Program resources (equip, personnel, etc.) for new campus. & DRM & TBD & TBD & & $4 Q$ & & & & & & & & & & & & \\
\hline $\begin{array}{l}\text { Explore relocating the community library in the Resiliency } \\
\text { Campus through the following activities: }\end{array}$ & & & & & & & & & & & & & & & & & \\
\hline
\end{tabular}

Total FTE Required for Goal 4: To initiate this goal, 0.3 FTE in FY11, 0.5 FTE in FY12, and 0.1 FTE in FY13, and FTEs required for other various actions is TBD.

Total Funding Required for Goal 4: \$11k in FY12, \$500k in FY13, and \$16M for new fitness facilities (schedule is MCAdependent). The funding for other various actions is TBD. 


\begin{tabular}{|c|c|c|c|c|c|c|c|c|c|c|c|c|c|c|c|c|c|}
\hline Actions for Objective 4.1 & $\begin{array}{l}\text { Lead / } \\
\text { Proponent }\end{array}$ & $\begin{array}{l}\text { Funding } \\
\text { Required }\end{array}$ & $\begin{array}{l}\text { Add'I FTE } \\
\text { Required }\end{array}$ & FY 11 & $\begin{array}{l}\text { FY } \\
12\end{array}$ & $\begin{array}{l}\mathrm{FY} \\
13\end{array}$ & $\begin{array}{l}\text { FY } \\
14\end{array}$ & $\begin{array}{l}\text { FY } \\
15\end{array}$ & $\begin{array}{l}\text { FY } \\
16\end{array}$ & $\begin{array}{l}\text { FY } \\
17\end{array}$ & $\begin{array}{l}\mathrm{FY} \\
18\end{array}$ & $\begin{array}{l}\text { FY } \\
19\end{array}$ & $\begin{array}{l}\mathrm{FY} \\
20\end{array}$ & $\begin{array}{l}\text { FY } \\
25\end{array}$ & $\begin{array}{l}\text { FY } \\
30\end{array}$ & $\begin{array}{l}\mathrm{FY} \\
35\end{array}$ & $\begin{array}{l}\mathrm{FY} \\
36\end{array}$ \\
\hline $\begin{array}{l}\text { Compare/evaluate existing Community Library services and } \\
\text { location to the proposed new facility for location, adequacy, } \\
\text { and quality of support to all users. }\end{array}$ & DFMWR & $\begin{array}{l}\text { DFMWR } \\
\$ 11 \mathrm{k}\end{array}$ & $240 \mathrm{hrs}$ & & $\begin{array}{c}2 \mathrm{Q}- \\
4 \mathrm{Q}\end{array}$ & & & & & & & & & & & & \\
\hline $\begin{array}{l}\text { Develop overall plan in conjunction with information ob- } \\
\text { tained above. }\end{array}$ & $\begin{array}{l}\text { DFMWR, } \\
\text { DPW }\end{array}$ & 0 & $120 \mathrm{hrs}$ & & $4 Q$ & $3 Q$ & & & & & & & & & & & \\
\hline Develop detailed cost estimate. & $\begin{array}{l}\text { DFMWR, } \\
\text { DPW }\end{array}$ & TBD & TBD & & & $\begin{array}{c}3 Q \\
- \\
4 Q\end{array}$ & & & & & & & & & & & \\
\hline Identify funding stream. & DFMWR & TBD & TBD & & & $\begin{array}{c}3 Q \\
- \\
4 Q\end{array}$ & & & & & & & & & & & \\
\hline
\end{tabular}


Goal 4 Description: Service Members, Families, and Civilians are provided opportunities,

programs and facilities enabling them to become resilient in mind, body, and spirit. Provide

holistic, consolidated and multi-functional (educational, physical fitness, recreational/leisure

and religious) services. Ensure all services are based on an ongoing needs assessment.

Objective 4.2: Provide access to state-of-the-art, after-hours-accessible classrooms and laboratories to improve all approved degree programs and educational opportunities.

Description: Improve continuing education, civilian degree programs, and all other off-duty training and education through upgrading and/or improved access to state-of-art classrooms and labs. May include facility development through partnerships with educational organizations (schools, universities).

Lead/Proponent: DHR-ESO.

FTE Required for Obj.4.2: 0.5 FTE in 3Q FY11-1Q FY12

Funding Required for Obj. 4.2: TBD

\begin{tabular}{|c|c|c|c|c|c|c|c|c|c|c|c|c|c|c|c|c|c|}
\hline Actions for Objective 4.2 & $\begin{array}{l}\text { Lead / } \\
\text { Proponent }\end{array}$ & $\begin{array}{l}\text { Funding } \\
\text { Required }\end{array}$ & $\begin{array}{l}\text { Add'I } \\
\text { FTE } \\
\text { Required }\end{array}$ & $\begin{array}{l}\mathrm{FY} \\
11\end{array}$ & $\begin{array}{l}\mathrm{FY} \\
12\end{array}$ & $\begin{array}{l}\mathrm{FY} \\
13\end{array}$ & $\begin{array}{l}\text { FY } \\
14\end{array}$ & $\begin{array}{l}\mathrm{FY} \\
15\end{array}$ & $\begin{array}{l}\mathrm{FY} \\
16\end{array}$ & $\begin{array}{l}\mathrm{FY} \\
17\end{array}$ & $\begin{array}{l}\mathrm{FY} \\
18\end{array}$ & $\begin{array}{l}\text { FY } \\
19\end{array}$ & $\begin{array}{l}\mathrm{FY} \\
20\end{array}$ & $\begin{array}{l}\text { FY } \\
25\end{array}$ & $\begin{array}{l}\mathrm{FY} \\
30\end{array}$ & $\begin{array}{l}\text { FY } \\
35\end{array}$ & $\begin{array}{l}\mathrm{FY} \\
36\end{array}$ \\
\hline $\begin{array}{l}\text { Gather a better understanding of how the relation- } \\
\text { ships/partnerships work between FLW and the education provid- } \\
\text { ers. }\end{array}$ & DHR- ESO & & 0.5 & & $4 Q$ & & & & & & & & & & & & \\
\hline $\begin{array}{l}\text { NOTE: Remaining actions will be developed or modified after first } \\
\text { action completed: }\end{array}$ & & & & & & & & & & & & & & & & & \\
\hline Develop baseline inventory of classrooms and labs. & & & & & & & & & & & & & & & & & \\
\hline Determine what/how many facilities are not state-of-art. & & & & & & & & & & & & & & & & & \\
\hline $\begin{array}{l}\text { Identify which facilities will be updated/upgraded/replaced by } \\
\text { existing project(s). }\end{array}$ & & & & & & & & & & & & & & & & & \\
\hline $\begin{array}{l}\text { Determine which education programs will/can be consid- } \\
\text { ered/supported by this objective. }\end{array}$ & & & & & & & & & & & & & & & & & \\
\hline $\begin{array}{l}\text { Determine what can be accomplished through partnerships vs. } \\
\text { what would require MCA. }\end{array}$ & & & & & & & & & & & & & & & & & \\
\hline
\end{tabular}


Goal 4 Description: Service Members, Families, and Civilians are provided opportunities, programs and facilities enabling them to become resilient in mind, body, and spirit. Provide holistic, consolidated and multi-functional (educational, physical fitness, recrea-

tional/leisure and religious) services. Ensure all services are based on an ongoing needs assessment.

Objective 4.3: Construct diverse, interconnected trail system.

Description: Linked to Mark Twain National Forest and local municipalities. Includes bicycle, pedestrian and PARCoURS trails/use with various physical fitness, recreation, and leisure stations. Will also support distance training for service members.

\section{Lead/Proponent: DFMWR}

FTE Required for Obj.4.3: 40 hours total in 3Q FY11-1Q FY12 + additional FTE is TBD

Funding Required for Obj. 4.3: TBD

\begin{tabular}{|c|c|c|c|c|c|c|c|c|c|c|c|c|c|c|c|c|c|}
\hline Actions for Objective 4.3 & $\begin{array}{l}\text { Lead / } \\
\text { Proponent }\end{array}$ & $\begin{array}{l}\text { Funding } \\
\text { Required }\end{array}$ & $\begin{array}{l}\text { Add'I FTE } \\
\text { Required }\end{array}$ & $\begin{array}{l}\mathrm{FY} \\
11\end{array}$ & $\begin{array}{l}\mathrm{FY} \\
12\end{array}$ & $\begin{array}{l}\mathrm{FY} \\
13\end{array}$ & $\begin{array}{l}\text { FY } \\
14\end{array}$ & $\begin{array}{l}\text { FY } \\
15\end{array}$ & $\begin{array}{l}\text { FY } \\
16\end{array}$ & $\begin{array}{l}\mathrm{FY} \\
17\end{array}$ & $\begin{array}{l}\text { FY } \\
18\end{array}$ & $\begin{array}{l}\text { FY } \\
19\end{array}$ & $\begin{array}{l}\text { FY } \\
20\end{array}$ & $\begin{array}{l}\text { FY } \\
25\end{array}$ & $\begin{array}{l}\mathrm{FY} \\
30\end{array}$ & $\begin{array}{l}\mathrm{FY} \\
35\end{array}$ & $\begin{array}{l}\mathrm{FY} \\
36\end{array}$ \\
\hline $\begin{array}{l}\text { Identify any plans local municipalities have with } \\
\text { recreational/leisure growth programs. }\end{array}$ & DFMWR & $\$ 0$ & $40 \mathrm{hrs}$ & & $4 Q$ & & & & & & & & & & & & \\
\hline $\begin{array}{l}\text { Develop overall plan in conjunction with infor- } \\
\text { mation obtained above. }\end{array}$ & $\begin{array}{l}\text { DFMWR, } \\
\text { DPW }\end{array}$ & TBD & TBD & & $4 Q$ & 30 & & & & & & & & & & & \\
\hline $\begin{array}{l}\text { Develop detailed cost estimate for planned trail } \\
\text { system. }\end{array}$ & $\begin{array}{l}\text { DFMWR, } \\
\text { DPW }\end{array}$ & TBD & TBD & & $4 Q$ & 10 & & & & & & & & & & & \\
\hline Identify funding stream. & DFMWR & TBD & TBD & & & $\begin{array}{c}10- \\
3 Q\end{array}$ & & & & & & & & & & & \\
\hline Execute plan. & DFMWR & TBD & TBD & & & & 10 & & & & & & & & & & \\
\hline
\end{tabular}


Goal 4 Description: Service Members, Families, and Civilians are provided opportunities, programs and facilities enabling them to become resilient in mind, body, and spirit. Provide holistic, consolidated and multi-functional (educational, physical fitness, recreational/leisure and religious) services. Ensure all services are based on an ongoing needs assessment.

Objective 4.4: Develop, maintain, and sustain facilities and capabilities on the Installation that support Soldier fitness and Family wellness.

Description: Construct indoor physical fitness, recreation, and leisure centers to accommodate growing population. Design and siting considerations should include access/availability of child care services. Includes support to all eligible users (ID card holders - service members, family members, retirees, eligible civilians). Develop and implement a strategy to approve and program additional indoor fitness recreation and leisure center space without being limited by BDE Fitness Centers counting against the Installation's authorized space. May include re-designation of BDE Gyms from Fitness Centers to Multi-use or other type of space since they are used for more than fitness training. Supports IMCOM SR1-3: Develop, maintain, and sustain facilities and capabilities on the installations that support Soldier fitness and a warrior ethos.

Lead/Proponent: DFMWR

FTE Required for Obj.4.4: 24 hours total in 2Q-3Q FY11 + additional FTE is TBD

Funding Required for Obj. 4.4: $\$ 500 \mathrm{k}$ in $1 \mathrm{Q}$ FY13 for design charrettes, approximately $\$ 16$ million for MCA fitness center in FY14, and funding for the other activities is TBD

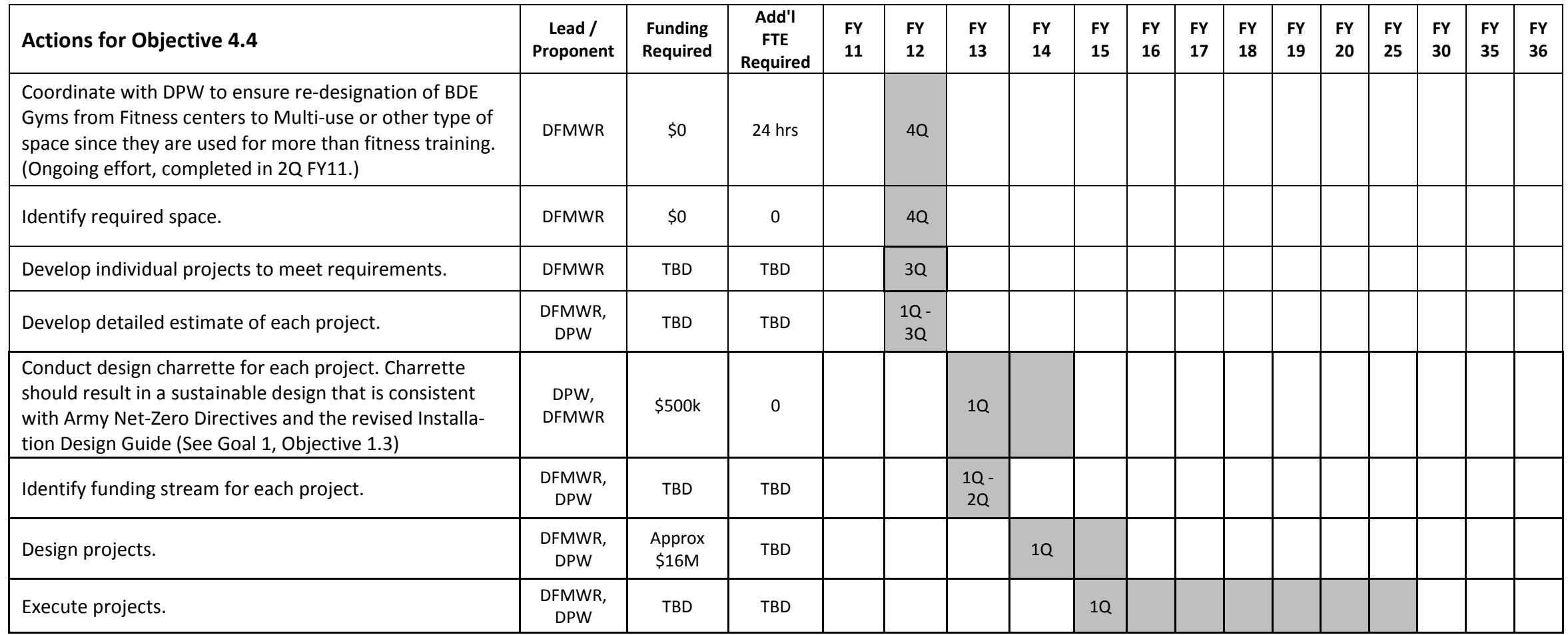


Goal 5 Description: FLW has a sustainable workforce that utilizes employment services and educational opportunities so that it: 1) Meets rapidly changing mission requirements; 2) Has a high level of total fitness and well-being (mental, spiritual, emotional, physical health); 3 ) Is demographically blended (mix of military, retiree, spouses and local and external talent, ages, races, gender); 4) Transitions institutional knowledge within workforce from experienced to new workers; 5) Has technical knowledge, certification, degrees, ongoing training, licenses; 6) Is motivated through incentives, rewards, recognition; 7) Feels they are stakeholders in mission accomplishment; 8) Has physical facilities and an organizational working environment that support high performance; 9) Operates within positive people dynamics; and 10) Believes individual and career growth is institutionally and socially encouraged, rewarded, supported, and balanced with organizational missions and community goals.
Total FTE Required for Goal 5: Approx. 1.1 FTE in FY11, 4.6 $\mathrm{FTE} / \mathrm{yr}$ in FY12-13, 4.3 FTE/yr in FY14-20, 3.3 FTE/yr in FY2125, 2.25 FTE/yr in FY26-35, and 1.25 FTE in FY36.

Total Funding Required for Goal 5: \$575k in FY11, \$981k in FY12 (includes 15 new kiosks), \$635k in FY13, \$725k in FY14 (includes 15 new kiosks), \$675k in FY15, \$635k/yr in FY16$19, \$ 675 \mathrm{k}$ in FY20, $\$ 185 \mathrm{k} / \mathrm{yr}$ in FY21-24, $\$ 225 \mathrm{k}$ in FY25, $\$ 185 \mathrm{k} / \mathrm{yr}$ in FY26-29, \$225k in FY30, \$185k/yr in FY31-34, $\$ 225 \mathrm{k}$ in FY35, and \$185k in FY36.

Objective 5.1: FLW community fully utilizes employment services.

Description: Workforce organizations work to ensure that the FLW community is aware of, has access to, and can properly utilize all available employment services, both Federal and local.

Lead/Proponent: DHR.

FTE Required for Obj.5.1: 0.25 FTE in 3Q FY11-36 and 1.0 FTE in 1Q FY12-36

Funding Required for Obj. 5.1: $\$ 50 \mathrm{k} / \mathrm{yr}$ inFY11-36

\begin{tabular}{|c|c|c|c|c|c|c|c|c|c|c|c|c|c|c|c|c|c|}
\hline Actions for Objective 5.1 & $\begin{array}{l}\text { Lead / } \\
\text { Proponent }\end{array}$ & $\begin{array}{l}\text { Funding } \\
\text { Required }\end{array}$ & $\begin{array}{c}\text { Add'I } \\
\text { FTE } \\
\text { Required }\end{array}$ & $\begin{array}{l}\mathrm{FY} \\
11\end{array}$ & $\begin{array}{l}\mathrm{FY} \\
12\end{array}$ & $\begin{array}{l}\mathrm{FY} \\
13\end{array}$ & $\begin{array}{l}\mathrm{FY} \\
14\end{array}$ & $\begin{array}{l}\mathrm{FY} \\
15\end{array}$ & $\begin{array}{l}\mathrm{FY} \\
16\end{array}$ & $\begin{array}{l}\text { FY } \\
17\end{array}$ & $\begin{array}{l}\mathrm{FY} \\
18\end{array}$ & $\begin{array}{l}\mathrm{FY} \\
19\end{array}$ & $\begin{array}{l}\mathrm{FY} \\
20\end{array}$ & $\begin{array}{l}\mathrm{FY} \\
25\end{array}$ & $\begin{array}{l}\mathrm{FY} \\
30\end{array}$ & $\begin{array}{l}\mathrm{FY} \\
35\end{array}$ & \begin{tabular}{|l|}
$\mathrm{FY}$ \\
36
\end{tabular} \\
\hline $\begin{array}{l}\text { Fill existing workforce development specialist (GS-13) position to } \\
\text { support Goal } 5 .\end{array}$ & DHR & & 1 & & 30 & & & & & & & & & & & & \\
\hline $\begin{array}{l}\text { Baseline usage of services for all military personnel who might use } \\
\text { services - one organization to track for all organizations that pro- } \\
\text { vide services. Coordinate with Missouri Career Center to identify } \\
\text { opportunities to improve services and promote greater use. }\end{array}$ & DHR & & & & 30 & & & & & & & & & & & & \\
\hline $\begin{array}{l}\text { Market the use of and encourage the community/state to main- } \\
\text { tain and streamline a centralized/single point of entry for all jobs } \\
\text { in the region (ties back to the existing programs and systems) to } \\
\text { provide employment assistance for military, civilians and their } \\
\text { family members per IMCOM CP SW3-4. (Tie back to the FLW mar- } \\
\text { keting under Goal 4). (Ongoing effort, completion date is blank.) }\end{array}$ & STRATCOM & $\$ 50 \mathrm{k} / \mathrm{yr}$ & 0.25 & & 30 & & & & & & & & & & & & \\
\hline
\end{tabular}




\begin{tabular}{|c|c|c|c|c|c|c|c|c|c|c|c|c|c|c|c|c|c|}
\hline Actions for Objective 5.1 & $\begin{array}{l}\text { Lead / } \\
\text { Proponent }\end{array}$ & $\begin{array}{l}\text { Funding } \\
\text { Required }\end{array}$ & $\begin{array}{l}\text { Add'l } \\
\text { FTE } \\
\text { Required }\end{array}$ & $\begin{array}{l}\text { FY } \\
11\end{array}$ & $\begin{array}{l}\text { FY } \\
12\end{array}$ & $\begin{array}{l}\text { FY } \\
13\end{array}$ & $\begin{array}{l}\text { FY } \\
14\end{array}$ & $\begin{array}{l}\text { FY } \\
15\end{array}$ & $\begin{array}{l}\text { FY } \\
16\end{array}$ & $\begin{array}{l}\mathrm{FY} \\
17\end{array}$ & $\begin{array}{l}\text { FY } \\
18\end{array}$ & $\begin{array}{l}\text { FY } \\
19\end{array}$ & $\begin{array}{l}\text { FY } \\
20\end{array}$ & $\begin{array}{l}\text { FY } \\
25\end{array}$ & $\begin{array}{l}\mathrm{FY} \\
30\end{array}$ & $\begin{array}{l}\mathrm{FY} \\
35\end{array}$ & $\begin{array}{l}\text { FY } \\
36\end{array}$ \\
\hline $\begin{array}{l}\text { Baseline number of military spouses who are unemployed and } \\
\text { have tried but were unable to find jobs at FLW or in the local } \\
\text { economy. Integrate data and track through ACAP/Missouri Career } \\
\text { Center. }\end{array}$ & DHR/ DEERS & & & & $2 Q$ & & & & & & & & & & & & \\
\hline $\begin{array}{l}\text { Positions outside the gate (MO Career Center) - link to jobs site on } \\
\text { post if not already linked. (COMPLETED) }\end{array}$ & CPAC & & & \multicolumn{6}{|c|}{ Initiated and completed 4Q FY10 } & & & & & & & & \\
\hline $\begin{array}{l}\text { User-friendly support that helps spouses/students prepare for and } \\
\text { conduct job searches, resume submission, and interviews. }\end{array}$ & $\begin{array}{l}\text { ACS Employ- } \\
\text { ment Readi- } \\
\text { ness }\end{array}$ & & & & $3 Q$ & & & & & & & & & & & & \\
\hline
\end{tabular}


Goal 5 Description: FLW has a sustainable workforce that utilizes employment services and educational opportunities so that it: 1) Meets rapidly changing mission requirements; 2) Has a high level of total fitness and well-being (mental, spiritual, emotional, physical health); 3 ) Is demographically blended (mix of military, retiree, spouses and local and external talent, ages, races, gender); 4) Transitions institutional knowledge within workforce from experienced to new workers; 5) Has technical knowledge, certification, degrees, ongoing training, licenses; 6) Is motivated through incentives, rewards, recognition; 7) Feels they are stakeholders in mission accomplishment; 8) Has physical facilities and an organizational working environment that support high performance; 9) Operates within positive people dynamics; and 10) Believes individual and career growth is institutionally and socially encouraged, rewarded, supported and balanced with organizational missions and community goals.

Objective 5.2: FLW provides opportunities and encouragement for technical knowledge, certification, degrees, ongoing training, and licenses for the workforce (through posted training events, partnerships, and tenants, etc.) to build a professional, skilled workforce best positioned to support the mission. Description: Create an environment where the FLW community is motivated to identify, receive, and document value-added training to ensure that training and education needs are identified and appropriate courses are provided to meet those needs. Training is easily accessible, convenient, and timely.

\section{Lead/Proponent: DHR}

FTE Required for Obj.5.2: 1.0 FTE G37 in 3Q FY11-20 to implement Army Learning Plan (2015-2020), 0.1 FTE DHR, 0.1 FTE CPAC, and 0.1 FTE G37 in 4Q FY11-13, and 0.5 FTE CPAC and 0.5 FTE G37 in 1Q FY12-35.

Funding Required for Obj. 5.2: $\$ 300 \mathrm{k} / \mathrm{yr}$ to implement Army Learning Plan (2015-2020)

\begin{tabular}{|c|c|c|c|c|c|c|c|c|c|c|c|c|c|c|c|c|c|}
\hline Actions for Objective 5.2 & $\begin{array}{c}\text { Lead / } \\
\text { Proponent }\end{array}$ & $\begin{array}{l}\text { Funding } \\
\text { Required }\end{array}$ & $\begin{array}{l}\text { Add'I FTE } \\
\text { Required }\end{array}$ & $\begin{array}{l}\mathrm{FY} \\
11\end{array}$ & $\begin{array}{l}\mathrm{FY} \\
12\end{array}$ & $\begin{array}{l}\text { FY } \\
13\end{array}$ & $\begin{array}{l}F Y \\
14\end{array}$ & $\begin{array}{l}\mathrm{FY} \\
15\end{array}$ & $\begin{array}{l}\mathrm{FY} \\
16\end{array}$ & $\begin{array}{l}\text { FY } \\
17\end{array}$ & $\begin{array}{l}\mathrm{FY} \\
18\end{array}$ & $\begin{array}{l}\text { FY } \\
19\end{array}$ & $\begin{array}{l}\mathrm{FY} \\
20\end{array}$ & $\begin{array}{l}\mathrm{FY} \\
25\end{array}$ & $\begin{array}{l}\mathrm{FY} \\
30\end{array}$ & $\begin{array}{l}\mathrm{FY} \\
35\end{array}$ & $\begin{array}{l}\text { FY } \\
36\end{array}$ \\
\hline $\begin{array}{l}\text { Establish mechanisms to ensure appropriate use of Individual } \\
\text { Development Plans installation-wide. Develop baseline of } \\
\text { number of employees currently meeting IDPs. For mission- } \\
\text { side, CPAC uses Command Inspection Review (change of } \\
\text { Command) to review/inspect percentage compliance with } \\
\text { training requirements. }\end{array}$ & $\begin{array}{l}\text { DHR \& } \\
\text { CPAC }\end{array}$ & & $\begin{array}{c}\text { Workforce } \\
\text { Develop- } \\
\text { ment } \\
\text { Specialist } \\
\text { (see Obj. } \\
5.1 \text { ) }\end{array}$ & & $4 Q$ & $2 Q$ & & & & & & & & & & & \\
\hline $\begin{array}{l}\text { Establish a performance objective for IDP conformance in all } \\
\text { supervisor/manager performance plans. Track training } \\
\text { (mandatory and developmental). Requires FTE support iden- } \\
\text { tified until established as standard procedure. After process } \\
\text { is established, monitoring and tracking will require less ef- } \\
\text { fort. Establish requirement in FY12 (1Q-4Q). Track progress } \\
\text { thereafter. }\end{array}$ & $\begin{array}{l}\text { All man- } \\
\text { agers } \\
\text { report } \\
\text { results to } \\
\text { DHR } \\
\text { Workforce } \\
\text { Develop- } \\
\text { ment } \\
\text { Specialist }\end{array}$ & & $\begin{array}{r}0.5 \text { CPAC } \\
+0.5 \text { G37 }\end{array}$ & & 10 & & & & & & & & & & & & \\
\hline
\end{tabular}




\begin{tabular}{|c|c|c|c|c|c|c|c|c|c|c|c|c|c|c|c|c|c|}
\hline Actions for Objective 5.2 & $\begin{array}{c}\text { Lead / } \\
\text { Proponent }\end{array}$ & $\begin{array}{l}\text { Funding } \\
\text { Required }\end{array}$ & $\begin{array}{l}\text { Add'I FTE } \\
\text { Required }\end{array}$ & $\begin{array}{l}\mathrm{FY} \\
11\end{array}$ & $\begin{array}{l}\mathrm{FY} \\
12\end{array}$ & $\begin{array}{l}\mathrm{FY} \\
13\end{array}$ & $\begin{array}{l}\text { FY } \\
14\end{array}$ & $\begin{array}{l}\mathrm{FY} \\
15\end{array}$ & $\begin{array}{l}\text { FY } \\
16\end{array}$ & $\begin{array}{l}\mathrm{FY} \\
17\end{array}$ & $\begin{array}{l}\mathrm{FY} \\
18\end{array}$ & $\begin{array}{l}\text { FY } \\
19\end{array}$ & $\begin{array}{l}\mathrm{FY} \\
20\end{array}$ & $\begin{array}{l}\mathrm{FY} \\
25\end{array}$ & $\begin{array}{l}\text { FY } \\
30\end{array}$ & $\begin{array}{l}\text { FY } \\
35\end{array}$ & $\begin{array}{l}\mathrm{FY} \\
36\end{array}$ \\
\hline $\begin{array}{l}\text { Establish ROI/benefit analysis that links individual perfor- } \\
\text { mance objectives to unit mission performance. Stress the } \\
\text { benefits of training your workforce in the supervisors HR } \\
\text { course (modify course). }\end{array}$ & $\begin{array}{l}\text { All man- } \\
\text { agers } \\
\text { report } \\
\text { results to } \\
\text { DHR } \\
\text { Workforce } \\
\text { Develop- } \\
\text { ment } \\
\text { Specialist }\end{array}$ & & $\begin{array}{c}0.1 \mathrm{DHR}+ \\
0.1 \mathrm{CPAC} \\
+0.1 \mathrm{G} 37\end{array}$ & & $3 Q$ & & & & & & & & & & & & \\
\hline $\begin{array}{l}\text { Participation rates in education and training services: docu- } \\
\text { ment course offered and participation rate (\% of available } \\
\text { slots used). Emphasize the Civilian Education System (CES). }\end{array}$ & CPAC/ G37 & & & & $3 Q$ & & & & & & & & & & & & \\
\hline Implement Army Learning Plan for 2015-2020. & G37 & $\$ 300 k / y r$ & 1.0 & & $3 Q$ & & & & & & & & & & & & \\
\hline $\begin{array}{l}\text { Use existing and future partnerships to extend course } \\
\text { equivalent credits to civilians (Enlisted, Warrant, and Offic- } \\
\text { ers) who have taken military courses previously to apply to } \\
\text { degree programs (as per LW5-2): }\end{array}$ & DHR & & & & $3 Q$ & & & & & & & & & & & & \\
\hline $\begin{array}{l}\text { - Develop Civilian Military Police Bachelor's and Master's } \\
\text { courses through educational system. Course would be opti- } \\
\text { mal if provided on-line to allow students to continue studies } \\
\text { regardless of station. }\end{array}$ & DHR & & & & $3 Q$ & & & & & & & & & & & & \\
\hline $\begin{array}{l}\text { - Develop Civilian CBRN Bachelor's and Master's degree } \\
\text { programs with educational system. Course would be optimal } \\
\text { if provided on-line to allow students to continue studies re- } \\
\text { gardless of station. }\end{array}$ & DHR & & & & $3 Q$ & & & & & & & & & & & & \\
\hline $\begin{array}{l}\text { - Develop Civilian Engineers Bachelor's and Master's cours- } \\
\text { es through educational system. Course would be optimal if } \\
\text { provided on-line to allow students to continue studies re- } \\
\text { gardless of station. }\end{array}$ & DHR & & & & $3 Q$ & & & & & & & & & & & & \\
\hline $\begin{array}{l}\text { Link MSCoE Campaign Plan to NCO Academy to ex- } \\
\text { pand/promote participation in these programs by NCOs and } \\
\text { Warrant Officers. }\end{array}$ & JIIM-IA & & & & $3 Q$ & & & & & & & & & & & & \\
\hline
\end{tabular}


Goal 5 Description: FLW has a sustainable workforce that utilizes employment services and educational opportunities so that it: 1) Meets rapidly changing mission requirements; 2) Has a high level of total fitness and well-being (mental, spiritual, emotional, physical health); 3 ) Is demographically blended (mix of military, retiree, spouses and local and external talent, ages, races, gender); 4) Transitions institutional knowledge within workforce from experienced to new workers; 5) Has technical knowledge, certification, degrees, ongoing training, licenses; 6) Is motivated through incentives, rewards, recognition; 7) Feels they are stakeholders in mission accomplishment; 8) Has physical facilities and an organizational working environment that support high performance; 9) Operates within positive people dynamics; and 10) Believes individual and career growth is institutionally and socially encouraged, rewarded, supported and balanced with organizational missions and community goals.

Objective 5.3: Develop a workforce with strong leaders, continuity, and cross-functional support that builds unstoppable momentum for safe and sustainable use of land, energy (fuel and electricity), and materials.

Description: Integrate sustainability into the culture of the Fort Leonard Wood workforce and leadership. All work should be accomplished with sustainability (as well as safety and occupational health) integrated into all activities and decision-making.

\section{Lead/Proponent: DHR}

FTE Required for Obj.5.3: None, since the DHR Workforce Development Specialist and the PAIO Sustainability Coordinator are accounted for elsewhere in the action plan.

Funding Required for Obj. 5.3: \$306k in FY12 and \$150k/yr FY13-20

\begin{tabular}{|c|c|c|c|c|c|c|c|c|c|c|c|c|c|c|c|c|c|}
\hline Actions for Objective 5.3 & $\begin{array}{c}\text { Lead / } \\
\text { Proponent }\end{array}$ & $\begin{array}{l}\text { Funding } \\
\text { Required }\end{array}$ & $\begin{array}{l}\text { Add'I } \\
\text { FTE } \\
\text { Required }\end{array}$ & $\begin{array}{l}\mathrm{FY} \\
11\end{array}$ & $\begin{array}{l}\text { FY } \\
12\end{array}$ & $\begin{array}{l}\text { FY } \\
13\end{array}$ & $\begin{array}{l}F Y \\
14\end{array}$ & $\begin{array}{l}\text { FY } \\
15\end{array}$ & $\begin{array}{l}\mathrm{FY} \\
16\end{array}$ & $\begin{array}{l}\text { FY } \\
17\end{array}$ & $\begin{array}{l}\mathrm{FY} \\
18\end{array}$ & $\begin{array}{l}\text { FY } \\
19\end{array}$ & $\begin{array}{l}\mathrm{FY} \\
20\end{array}$ & $\begin{array}{l}\mathrm{FY} \\
25\end{array}$ & $\begin{array}{l}\text { FY } \\
30\end{array}$ & $\begin{array}{l}\text { FY } \\
35\end{array}$ & $\begin{array}{l}\text { FY } \\
36\end{array}$ \\
\hline $\begin{array}{l}\text { Train/educate workers to be more aware of their usage of } \\
\text { water, energy, materials to shift toward more conserva- } \\
\text { tive use of resources. Promote recycling website. (Initiat- } \\
\text { ed } 1 Q 11 \text { and ongoing). }\end{array}$ & $\begin{array}{l}\text { DHR Work- } \\
\text { force Devel- } \\
\text { opment } \\
\text { Specialist }\end{array}$ & $\$ 150 \mathrm{k} / \mathrm{yr}$ & & & $3 Q$ & & & & & & & & & & & & \\
\hline - Put sustainability message on MSCoE monitors & & & & & $3 Q$ & & & & & & & & & & & & \\
\hline - Integrate sustainability message into all social events & & & & & $3 Q$ & & & & & & & & & & & & \\
\hline - Media outreach spots & & & & & $3 Q$ & & & & & & & & & & & & \\
\hline
\end{tabular}




\begin{tabular}{|c|c|c|c|c|c|c|c|c|c|c|c|c|c|c|c|c|c|}
\hline Actions for Objective 5.3 & $\begin{array}{c}\text { Lead / } \\
\text { Proponent }\end{array}$ & $\begin{array}{l}\text { Funding } \\
\text { Required }\end{array}$ & $\begin{array}{c}\text { Add'I } \\
\text { FTE } \\
\text { Required } \\
\end{array}$ & $\begin{array}{l}\mathrm{FY} \\
11\end{array}$ & $\begin{array}{l}\mathrm{FY} \\
12\end{array}$ & $\begin{array}{l}\mathrm{FY} \\
13\end{array}$ & $\begin{array}{l}\mathrm{FY} \\
14\end{array}$ & $\begin{array}{l}\mathrm{FY} \\
15\end{array}$ & $\begin{array}{l}\mathrm{FY} \\
16\end{array}$ & $\begin{array}{l}\mathrm{FY} \\
17\end{array}$ & $\begin{array}{l}\text { FY } \\
18\end{array}$ & $\begin{array}{l}\mathrm{FY} \\
19\end{array}$ & $\begin{array}{l}\mathrm{FY} \\
20\end{array}$ & $\begin{array}{l}\mathrm{FY} \\
25\end{array}$ & $\begin{array}{l}\mathrm{FY} \\
30\end{array}$ & $\begin{array}{l}\mathrm{FY} \\
35\end{array}$ & $\begin{array}{l}\mathrm{FY} \\
36\end{array}$ \\
\hline $\begin{array}{l}\text { - Partner with universities for interns to support sustain- } \\
\text { ability program }\end{array}$ & & & & & $3 Q$ & & & & & & & & & & & & \\
\hline $\begin{array}{l}\text { - Develop web materials on Daily Blast site and public } \\
\text { website }\end{array}$ & & & & & $3 Q$ & & & & & & & & & & & & \\
\hline $\begin{array}{l}\text { Develop a plan for and implement a comprehensive recy- } \\
\text { cling program: }\end{array}$ & DPW ENV & $\$ 150 \mathrm{k}$ & & & $\begin{array}{c}2 Q- \\
4 Q\end{array}$ & & & & & & & & & & & & \\
\hline - Promote internal communications program & & & & & $4 Q$ & & & & & & & & & & & & \\
\hline — Locate recycle bins everywhere & & & & & $4 Q$ & & & & & & & & & & & & \\
\hline - Fix QRP to have funds to pay for recycling contracting & & & & & $4 Q$ & & & & & & & & & & & & \\
\hline - Promote recycling website & & & & & $4 Q$ & & & & & & & & & & & & \\
\hline - Track progress and develop ROI/benefits analysis & & & & & $4 Q$ & & & & & & & & & & & & \\
\hline $\begin{array}{l}\text { Create incentives and provide information for alternative } \\
\text { transportation: (Initiated } 4 Q 10 \text {, completion date is blank.) }\end{array}$ & DPW & & & & 10 & & & & & & & & & & & & \\
\hline - Market existing services & & & & & 10 & & & & & & & & & & & & \\
\hline - Bike lanes & & & & & 10 & & & & & & & & & & & & \\
\hline - Additional motorcycle parking & & & & & 10 & & & & & & & & & & & & \\
\hline - Car pool (set up and reimburse from Fed program) & & & & & $1 Q$ & & & & & & & & & & & & \\
\hline - Special parking for carpools and ULEVs & & & & & 10 & & & & & & & & & & & & \\
\hline $\begin{array}{l}\text { Send GC and staffer to explore regional recycling coopera- } \\
\text { tive (e.g., Yellowstone model). Participants should include: }\end{array}$ & RCGA & $\$ 6 \mathrm{k}$ & & & $4 \mathrm{Q}$ & & & & & & & & & & & & \\
\hline - Counties and cities & & & & & $4 Q$ & & & & & & & & & & & & \\
\hline - Balfour-Beatty RCI & & & & & $4 Q$ & & & & & & & & & & & & \\
\hline - Garrison and tenants & & & & & $4 \mathrm{Q}$ & & & & & & & & & & & & \\
\hline $\begin{array}{l}\text { Integrate sustainability message into seasonal safety cam- } \\
\text { paigns. }\end{array}$ & Safety Office & & & & $4 Q$ & & & & & & & & & & & & \\
\hline $\begin{array}{l}\text { Identify functional area sustainability champions and inte- } \\
\text { grate sustainability objectives into performance reviews. } \\
\text { Provide time for working sustainability into their function- } \\
\text { al areas. }\end{array}$ & $\begin{array}{l}\text { DHR Work- } \\
\text { force Dev } \\
\text { Spec \& Org } \\
\text { Mgrs }\end{array}$ & & & & & 10 & & & & & & & & & & & \\
\hline
\end{tabular}


Goal 5 Description: FLW has a sustainable workforce that utilizes employment services and educational opportunities so that it: 1) Meets rapidly changing mission requirements; 2 ) Has a high level of total fitness and well-being (mental, spiritual, emotional, physical health); 3 ) Is demographically blended (mix of military, retiree, spouses and local and external talent, ages, races, gender); 4) Transitions institutional knowledge within workforce from experienced to new workers; 5) Has technical knowledge, certification, degrees, ongoing training, licenses; 6) Is motivated through incentives, rewards, recognition; 7) Feels they are stakeholders in mission accomplishment; 8) Has physical facilities and an organizational working environment that support high performance; 9) Operates within positive people dynamics; and 10) Believes individual and career growth is institutionally and socially encouraged, rewarded, supported and balanced with organizational missions and community goals.

Objective 5.4: Become an enlightened employer of choice that sustains a workforce that is adaptable, dynamic, collaborative, motivated, and functions sustainably in meeting current and future mission needs.

Description: FLW will meet rapidly changing mission requirements, transition institutional knowledge and address lack of specialized personnel (that will be compounded by future silver tsunami), through the development of a strong workforce through such mechanisms as internships, retention bonuses, internal training, and educational programs/development. FLW enhances its reputation by promoting its outstanding benefits including sustainable workplace options, health care, time for fitness and well-being, and opportunities to advance as incentives to attract skilled professionals. FLW workforce of supervisors and staff learn and advance in accordance with a staff succession plan as per IMCOM CP LW1-2. Develop and maintain a requirements-driven system of leadership development that builds breadth and depth in targeted leader competencies and meets Army and Installation Management needs as per IMCOM CP LW1-1. Installation needs to develop a workforce with creative ideas to accomplish the mission.

\section{Lead/Proponent: DHR}

FTE Required for Obj.5.4: Approx. 1.1 FTE for 4Q FY11 - 2025.

Funding Required for Obj. 5.4: \$225k in FY11, \$325k in FY12, \$135k in FY13, \$225k in FY14, \$135k in FY15-36 plus an additional \$40k in the years FY15, FY20, FY25, FY30, and FY35.

\begin{tabular}{|c|c|c|c|c|c|c|c|c|c|c|c|c|c|c|c|c|c|}
\hline Actions for Objective 5.4 & $\begin{array}{c}\text { Lead } \\
\text { Proponent }\end{array}$ & $\begin{array}{l}\text { Funding } \\
\text { Required }\end{array}$ & $\begin{array}{l}\text { Add'I FTE } \\
\text { Required }\end{array}$ & FY 11 & FY 12 & $\begin{array}{l}\text { FY } \\
13\end{array}$ & FY 14 & $\begin{array}{l}\mathrm{FY} \\
15\end{array}$ & $\begin{array}{l}\mathrm{FY} \\
16\end{array}$ & $\begin{array}{l}\text { FY } \\
17\end{array}$ & $\begin{array}{l}\mathrm{FY} \\
18\end{array}$ & $\begin{array}{l}\text { FY } \\
19\end{array}$ & $\begin{array}{l}\mathrm{FY} \\
20\end{array}$ & $\begin{array}{l}\mathrm{FY} \\
25\end{array}$ & $\begin{array}{l}\mathrm{FY} \\
30\end{array}$ & $\begin{array}{l}\mathrm{FY} \\
35\end{array}$ & $\begin{array}{l}\mathrm{FY} \\
36\end{array}$ \\
\hline $\begin{array}{l}\text { Develop a succession plan that enables installa- } \\
\text { tion management to anticipate and fill leader- } \\
\text { ship position vacancies. A system where tal- } \\
\text { ented/motivated employees are trained and } \\
\text { promoted to fill vacancies as per LW1-2. }\end{array}$ & $\begin{array}{c}\text { DHR \& CPAC } \\
\text { in conjunc- } \\
\text { tion with } \\
\text { managers }\end{array}$ & $\$ 100 k$ & 0 & & $\begin{array}{c}3 Q- \\
4 Q\end{array}$ & & & & & & & & & & & & \\
\hline Promote alternative hiring initiatives: & CPAC & $\$ 0$ & 0 & & $3 Q$ & & & & & & & & & & & & \\
\hline - Use Recent Graduation Program (RGP) & CPAC & $\$ 0$ & 0 & & $3 Q$ & & & & & & & & & & & & \\
\hline — STEP/SCEP & CPAC & $\$ 0$ & 0 & & $3 Q$ & & & & & & & & & & & & \\
\hline
\end{tabular}




\begin{tabular}{|c|c|c|c|c|c|c|c|c|c|c|c|c|c|c|c|c|c|}
\hline Actions for Objective 5.4 & $\begin{array}{l}\text { Lead } \\
\text { Proponent }\end{array}$ & $\begin{array}{l}\text { Funding } \\
\text { Required }\end{array}$ & $\begin{array}{l}\text { Add'I FTE } \\
\text { Required }\end{array}$ & FY 11 & FY 12 & $\begin{array}{l}\text { FY } \\
13\end{array}$ & FY 14 & $\begin{array}{l}\mathrm{FY} \\
15\end{array}$ & $\begin{array}{l}\mathrm{FY} \\
16\end{array}$ & $\begin{array}{l}\mathrm{FY} \\
17\end{array}$ & $\begin{array}{l}\mathrm{FY} \\
18\end{array}$ & $\begin{array}{l}\mathrm{FY} \\
19\end{array}$ & $\begin{array}{l}\mathrm{FY} \\
20\end{array}$ & $\begin{array}{l}\mathrm{FY} \\
25\end{array}$ & $\begin{array}{l}\mathrm{FY} \\
30\end{array}$ & $\begin{array}{l}\mathrm{FY} \\
35\end{array}$ & $\begin{array}{l}\mathrm{FY} \\
36\end{array}$ \\
\hline $\begin{array}{l}\text { Grow leaders who understand the value of } \\
\text { satisfied customers and stakeholders by using } \\
\text { feedback mechanisms (e.g., ICE) to evaluate } \\
\text { performance and program effectiveness as per } \\
\text { LW2-2: (Ongoing, completion date is blank.) }\end{array}$ & $\begin{array}{l}\text { PAIO - estab- } \\
\text { lished \& } \\
\text { working to } \\
\text { promote } \\
\text { greater use }\end{array}$ & $\$ 125 \mathrm{k} / \mathrm{yr}$ & 0 & & $3 Q$ & & & & & & & & & & & & \\
\hline $\begin{array}{l}\text { - Managers encouraged to consider ICE com- } \\
\text { ments when evaluating performance }\end{array}$ & PAIO & $\$ 0$ & 0 & & $3 Q$ & & & & & & & & & & & & \\
\hline $\begin{array}{l}\text { - GC requires ICE link added to all email signa- } \\
\text { ture blocks }\end{array}$ & PAIO & $\$ 0$ & 0 & & $4 Q$ & & & & & & & & & & & & \\
\hline $\begin{array}{l}\text { - ICE summaries distributed to teams evaluat- } \\
\text { ed }\end{array}$ & & $\$ 0$ & 0 & & $4 Q$ & & & & & & & & & & & & \\
\hline - Develop Facebook ICE Comment Collection & & $\$ 0$ & 0 & & $2 Q$ & $4 Q$ & & & & & & & & & & & \\
\hline $\begin{array}{l}\text {-ICE kiosks for all appropriate locations (30+ } \\
\text { areas) }\end{array}$ & PAIO & $\begin{array}{l}\$ 180 \mathrm{k} \text { for } \\
\text { new kiosks } \\
\& \$ 10 \mathrm{k} / \mathrm{yr} \\
\text { for maint }\end{array}$ & 0 & & $\begin{array}{l}\text { 1Q, } \\
4 Q: \\
15 \\
\text { new } \\
\text { kiosks }\end{array}$ & & $\begin{array}{c}4 \mathrm{Q}: \\
15 \\
\text { new } \\
\text { kiosks }\end{array}$ & & & & & & & & & & \\
\hline $\begin{array}{l}\text { Establish mini-training sessions for employees } \\
\text { on TAPES, IDPs, Staffing, Greening, etc. to sup- } \\
\text { port staff on their development (short periods } \\
\text { of time, on-site, no cost): }\end{array}$ & CPAC, G37 & $\$ 0$ & 1.0 & & $3 Q$ & & & & & & & & & & & & \\
\hline - Refresher on awards programs & & $\$ 0$ & 0 & & $3 Q$ & & & & & & & & & & & & \\
\hline $\begin{array}{l}\text { - Courses on career development skills (HR for } \\
\text { supervisors, career development, technical } \\
\text { skills, etc.) }\end{array}$ & & $\$ 0$ & 0 & & $3 Q$ & & & & & & & & & & & & \\
\hline $\begin{array}{l}\text { Re-establish an installation mentorship pro- } \\
\text { gram with people who want to be mentors: }\end{array}$ & CPAC & & 0.1 & & & $1 Q$ & & & & & & & & & & & \\
\hline $\begin{array}{l}\text { - Identify high-profile leaders to support men- } \\
\text { tor program }\end{array}$ & & & & & & $1 Q$ & & & & & & & & & & & \\
\hline $\begin{array}{l}\text { - Develop a program that doesn't negatively } \\
\text { impact the senior managers who participate }\end{array}$ & & & & & & 10 & & & & & & & & & & & \\
\hline $\begin{array}{l}\text { Baseline and quantify the benefits of various } \\
\text { sustainable workforce staffing tools (e.g., flex } \\
\text { time, job sharing, telecommuting, etc.). }\end{array}$ & CPAC & & 0.1 & & $\begin{array}{l}3 Q- \\
4 Q\end{array}$ & & & & & & & & & & & & \\
\hline $\begin{array}{l}\text { Use sustainable workforce tools (e.g., tele- } \\
\text { commuting, job sharing, etc.) that best support } \\
\text { mission and reduce impacts: }\end{array}$ & $\begin{array}{l}\text { CPAC to } \\
\text { coordinate } \\
\text { policy \& } \\
\text { outreach. } \\
\text { Mgrs decide. }\end{array}$ & $\begin{array}{l}\text { Cost differ- } \\
\text { ential be- } \\
\text { tween } \\
\text { desktops \& } \\
\text { laptops. }\end{array}$ & & & $3 Q$ & $1 Q$ & & & & & & & & & & & \\
\hline
\end{tabular}




\begin{tabular}{|c|c|c|c|c|c|c|c|c|c|c|c|c|c|c|c|c|c|}
\hline Actions for Objective 5.4 & $\begin{array}{c}\text { Lead } \\
\text { Proponent }\end{array}$ & $\begin{array}{l}\text { Funding } \\
\text { Required }\end{array}$ & $\begin{array}{l}\text { Add'I FTE } \\
\text { Required }\end{array}$ & FY 11 & FY 12 & $\begin{array}{l}\mathrm{FY} \\
13\end{array}$ & FY 14 & $\begin{array}{l}\text { FY } \\
15\end{array}$ & $\begin{array}{l}\mathrm{FY} \\
16\end{array}$ & $\begin{array}{l}\text { FY } \\
17\end{array}$ & $\begin{array}{l}\text { FY } \\
18\end{array}$ & $\begin{array}{l}\text { FY } \\
19\end{array}$ & $\begin{array}{l}\text { FY } \\
20\end{array}$ & $\begin{array}{l}\text { FY } \\
25\end{array}$ & $\begin{array}{l}\mathrm{FY} \\
30\end{array}$ & $\begin{array}{l}\mathrm{FY} \\
35\end{array}$ & $\begin{array}{l}\mathrm{FY} \\
36\end{array}$ \\
\hline - Address NEC issues & & & & & $3 Q$ & $1 Q$ & & & & & & & & & & & \\
\hline - Purchase laptops in place of desk tops & NEC G6 & & & & & $1 Q$ & & & & & & & & & & & \\
\hline — Track telecommuting hours & CPAC & & & & & $1 Q$ & & & & & & & & & & & \\
\hline $\begin{array}{l}\text { - Calculate benefits - miles saved, green } \\
\text { house gas reduction }\end{array}$ & DPW ENV & & & & & $2 Q$ & & & & & & & & & & & \\
\hline $\begin{array}{l}\text { Promote utilization of Army incentive awards } \\
\text { programs - honorary and monetary (numbers } \\
\text { presented annually): (Ongoing) }\end{array}$ & CPAC & & 0.1 & & $4 Q$ & & & & & & & & & & & & \\
\hline $\begin{array}{l}\text { - Advertise "ideas program" and potential } \\
\text { awards }\end{array}$ & CPAC & & & & $1 \mathrm{Q}$ & & & & & & & & & & & & \\
\hline $\begin{array}{l}\text { - Community of Excellence Awards - make } \\
\text { awards through this process }\end{array}$ & CPAC & & & & $1 Q$ & & & & & & & & & & & & \\
\hline - Instructor of the Year program & G3 & & & & $1 Q$ & & & & & & & & & & & & \\
\hline - Soldier of the Quarter program & G3 & & & & $1 \mathrm{Q}$ & & & & & & & & & & & & \\
\hline - Local awards/significant achievement & CPAC & & & & 10 & & & & & & & & & & & & \\
\hline $\begin{array}{l}\text { Educate managers on the use of all of these } \\
\text { programs so they will utilize them. }\end{array}$ & CPAC & & & & $2 Q$ & $2 Q$ & & & & & & & & & & & \\
\hline $\begin{array}{l}\text { Find a mechanism for managers to benchmark } \\
\text { off each other. }\end{array}$ & CPAC & & & & & $\begin{array}{c}1 Q- \\
2 Q\end{array}$ & & & & & & & & & & & \\
\hline $\begin{array}{l}\text { Establish evaluation process to determine ROI } \\
\text { on how new/renovated buildings are impacting } \\
\text { worker performance: }\end{array}$ & DPW & $\$ 100 k$ & & & $3 Q$ & $2 Q$ & & & & & & & & & & & \\
\hline - Baseline current absenteeism & & & & & & & & & & & & & & & & & \\
\hline - Ergonomics & & & & & & & & & & & & & & & & & \\
\hline - Healthy space & & & & & & & & & & & & & & & & & \\
\hline — Lighting & & & & & & & & & & & & & & & & & \\
\hline - Indoor air quality and temperature control & & & & & & & & & & & & & & & & & \\
\hline $\begin{array}{l}\text { Partners: Occupational health/partner with } \\
\text { university/feed information back to DPW. }\end{array}$ & & & & & & & & & & & & & & & & & \\
\hline $\begin{array}{l}\text { Evaluate whether or not infrastructure sup- } \\
\text { ports workforce productivity, happiness, and } \\
\text { healthy workplaces. }\end{array}$ & DPW & $\begin{array}{l}\text { \$40k each } \\
\text { yr evaluat- } \\
\text { ed (every } 5 \\
\text { yrs) }\end{array}$ & & & & & & $\begin{array}{c}1 Q- \\
4 Q\end{array}$ & & & & & $\begin{array}{l}1 Q- \\
4 Q\end{array}$ & $\begin{array}{l}1 Q- \\
4 Q\end{array}$ & $\begin{array}{l}1 Q- \\
4 Q\end{array}$ & $\begin{array}{l}1 Q- \\
4 Q\end{array}$ & \\
\hline
\end{tabular}


Goal 6 Description: Identify, provide, operate, sustain, and protect the training areas, ranges, and facilities needed to support current and future missions conducted at FLW.
Total FTE Required for Goal 6: Approx. 1.6 FTE in FY11, 2.6 FTE in FY12, 3.0 FTE in FY13, 2.5 FTE in FY14-25, and 1.5 FTE in FY26-36. Total Funding Required for Goal 6: \$310k/yr in FY11-12, \$60k/yr for FY13-36 + funding for various tasks is TBD.

Objective 6.1: Accurate, timely, and complete identification of training facilities, ranges, and land requirements.

Description: Improve how training assets requirements are identified, collected, and conveyed to the Garrison from the supported units/organizations. Streamline process for identifying requirements. Training units land and range requirements are input into the Army Range Requirements Model (ARRM) when commandant-approved POIs are sent to TRADOC Training Operations Management Activity (TOMA). Therefore, School Commandants/G3 must ensure that POI developers have identified all training area, land, facility, and road requirements, and that they are correctly annotated in the POIs before they are sent to TOMA for validation. There is a constant backlog on POI development. Schools are forced to adjust training based on emerging lessons learned and best practices vs. current POIs to ensure training stays current and relevant. This creates a lag in identifying the changes to include increased utilization or new facility requirements training. Requirements for FLW-supported Operational Units and other tenant organizations, as identified in the Army Stationing and Installation Plan, primarily come from Combined Arms Training Strategies (CATS) and Standards in Training Commission (STRAC) guidance. Similar to POIs, CATS, and STRAC generally lag in capturing Commander's training requirements. A streamlined process needs to link G3 to CATS and STRAC proponents, as well as force design and modernization activities to be able to adequately forecast requirement changes. Process must include tracking of changes while under development through approval, capturing the MSCOE Sustainable Range Program doctrinal analysis, then verification of requirements in the ARRM.

Lead/Proponent: G3

FTE Required for Obj. 6.1: 0.9 FTE in FY11, 1.1 FTE in FY12, and 1.0 FTE in FY13-36.

Funding Required for Obj. 6.1: \$0

\begin{tabular}{|c|c|c|c|c|c|c|c|c|c|c|c|c|c|c|c|c|c|}
\hline Actions for Objective 6.1 & $\begin{array}{l}\text { Lead } \\
\text { Proponent }\end{array}$ & $\begin{array}{l}\text { Funding } \\
\text { Required }\end{array}$ & $\begin{array}{l}\text { Add'I } \\
\text { FTE } \\
\text { Required }\end{array}$ & FY 11 & $\begin{array}{l}\mathrm{FY} \\
12\end{array}$ & $\begin{array}{l}\mathrm{FY} \\
13\end{array}$ & $\begin{array}{l}\mathrm{FY} \\
14\end{array}$ & $\begin{array}{l}\mathrm{FY} \\
15\end{array}$ & $\begin{array}{l}\text { FY } \\
16\end{array}$ & $\begin{array}{l}\mathrm{FY} \\
17\end{array}$ & $\begin{array}{l}\mathrm{FY} \\
18\end{array}$ & $\begin{array}{l}\text { FY } \\
19\end{array}$ & $\begin{array}{l}\mathrm{FY} \\
20\end{array}$ & $\begin{array}{l}\mathrm{FY} \\
25\end{array}$ & $\begin{array}{l}\mathrm{FY} \\
30\end{array}$ & $\begin{array}{l}\mathrm{FY} \\
35\end{array}$ & $\begin{array}{l}\mathrm{FY} \\
36\end{array}$ \\
\hline $\begin{array}{l}\text { Provide certified ASIP and station plans that are not } \\
\text { contained in the ASIP for analysis to G-3. }\end{array}$ & PAIO & $\$ 0$ & 0 & $4 Q$ & $4 \mathrm{Q}$ & $4 Q$ & $4 Q$ & $4 Q$ & $4 \mathrm{Q}$ & 4Q & 4Q & 4Q & $4 \mathrm{Q}$ & $4 \mathrm{Q}$ & $4 \mathrm{Q}$ & $4 Q$ & $4 Q$ \\
\hline $\begin{array}{l}\text { Identify/define the current process(es) of how require- } \\
\text { ments are transmitted to garrison. (COMPLETED) }\end{array}$ & G3 & $\$ 0$ & 0.2 & $\begin{array}{l}\text { 30 Start \& } \\
\text { End }\end{array}$ & & & & & & & & & & & & & \\
\hline $\begin{array}{l}\text { Identify if process(es) can be streamlined/improved to } \\
\text { be more responsive. (COMPLETED; NEEDS FOR } \\
\text { IMPROVEMENT IDENTIFIED) }\end{array}$ & G3 & $\$ 0$ & 0.2 & $3 Q-4 Q$ & & & & & & & & & & & & & \\
\hline $\begin{array}{l}\text { Develop projects/policies/programs/methods to im- } \\
\text { prove/streamline process(es). (COMPLETED) }\end{array}$ & G3 & $\$ 0$ & 0.2 & 30 & $4 Q$ & & & & & & & & & & & & \\
\hline
\end{tabular}




\begin{tabular}{|c|c|c|c|c|c|c|c|c|c|c|c|c|c|c|c|c|c|}
\hline Actions for Objective 6.1 & $\begin{array}{c}\text { Lead } \\
\text { Proponent }\end{array}$ & $\begin{array}{l}\text { Funding } \\
\text { Required }\end{array}$ & $\begin{array}{c}\text { Add'I } \\
\text { FTE } \\
\text { Required }\end{array}$ & FY 11 & $\begin{array}{l}\mathrm{FY} \\
12\end{array}$ & $\begin{array}{l}\mathrm{FY} \\
13\end{array}$ & $\begin{array}{l}\text { FY } \\
14\end{array}$ & $\begin{array}{l}\mathrm{FY} \\
15\end{array}$ & $\begin{array}{l}\mathrm{FY} \\
16\end{array}$ & $\begin{array}{l}\mathrm{FY} \\
17\end{array}$ & $\begin{array}{l}\text { FY } \\
18\end{array}$ & $\begin{array}{l}\mathrm{FY} \\
19\end{array}$ & $\begin{array}{l}\mathrm{FY} \\
20\end{array}$ & $\begin{array}{l}\mathrm{FY} \\
25\end{array}$ & $\begin{array}{l}\mathrm{FY} \\
\mathbf{3 0}\end{array}$ & $\begin{array}{l}\mathrm{FY} \\
35\end{array}$ & $\begin{array}{l}\mathrm{FY} \\
36\end{array}$ \\
\hline $\begin{array}{l}\text { G-3 develops policy and procedure that ensures staffing } \\
\text { of requirement documents through G-3 and MSCoE } \\
\text { resource managers before approval and submission to } \\
\text { TRADOC. }\end{array}$ & G3 & $\$ 0$ & & & $4 Q$ & & & & & & & & & & & & \\
\hline $\begin{array}{l}\text { G3 engages TRADOC-level range proponent working } \\
\text { group meetings in support of presenting new MSCoE } \\
\text { proponent requirements so TC25-1 and } 25-8 \text { are updat- } \\
\text { ed. G3 will continue this engagement for all require- } \\
\text { ments. (PROCESS IMPLEMENTED) (COMPLETE) }\end{array}$ & G3 & $\$ 0$ & 0.2 & $4 Q$ & $1 \mathrm{Q}$ & & & & & & & & & & & & \\
\hline $\begin{array}{l}\text { Provide validated requirements to DPW and DPTM for } \\
\text { RDP and RPMP for inclusion. }\end{array}$ & G3 & $\$ 0$ & 1.0 & $3 Q$ & $2 Q$ & $2 Q$ & $2 Q$ & $2 Q$ & $2 Q$ & $2 Q$ & $2 Q$ & $2 Q$ & $2 Q$ & $2 Q$ & $2 Q$ & $2 Q$ & $2 Q$ \\
\hline
\end{tabular}


Table B-49. Objective 6.2 Action Plan.

Goal 6 Description: Identify, provide, operate, sustain, and protect the training areas,

ranges, and facilities needed to support current and future missions conducted at FLW.

Objective 6.2: Develop plan and implement an acquisition strategy to provide modern, adaptable, sustainable, and high-performance training facilities on FLW for all training requirements.

Description: Develop sufficient capabilities so that units can accomplish all required training on FLW in accordance with the doctrinal analysis. Develop multipurpose ranges and facilities as much as possible. May be implemented through various funding and management methods (i.e., Range Development Plan (RDP), Range Complex Master Plan (RCMP)). Includes taking advantage of existing/available mission encroachment planning tools to help optimize the location and development of new ranges/training areas and eliminate or reduce any potential limitations/constraints.

Lead/Proponent: DPW Master Planner

\section{FTE Required for Obj. 6.2: 0.5 FTE in 3Q FY11-2036}

Funding Required for Obj. 6.2: Approximately \$250k in FY12 and \$60k/yr for charrettes in FY11-2036.

\begin{tabular}{|c|c|c|c|c|c|c|c|c|c|c|c|c|c|c|c|c|c|}
\hline Actions for Objective 6.2 & $\begin{array}{c}\text { Lead } \\
\text { Proponent }\end{array}$ & $\begin{array}{l}\text { Funding } \\
\text { Required }\end{array}$ & $\begin{array}{l}\text { Add'I } \\
\text { FTE } \\
\text { Required }\end{array}$ & FY 11 & $\begin{array}{l}\mathrm{FY} \\
12\end{array}$ & $\begin{array}{l}\text { FY } \\
13\end{array}$ & $\begin{array}{l}\text { FY } \\
14\end{array}$ & $\begin{array}{l}\text { FY } \\
15\end{array}$ & $\begin{array}{l}\mathrm{FY} \\
16\end{array}$ & $\begin{array}{l}\mathrm{FY} \\
17\end{array}$ & $\begin{array}{l}\mathrm{FY} \\
18\end{array}$ & $\begin{array}{l}\mathrm{FY} \\
19\end{array}$ & $\begin{array}{l}\mathrm{FY} \\
20\end{array}$ & $\begin{array}{l}\text { FY } \\
25\end{array}$ & $\begin{array}{l}\text { FY } \\
30\end{array}$ & $\begin{array}{l}\mathrm{FY} \\
35\end{array}$ & $\begin{array}{l}\mathrm{FY} \\
36\end{array}$ \\
\hline $\begin{array}{l}\text { Develop process to review validated requirements from } \\
\text { Obj. } 6.1 \text { and determine how they will be filled that is more } \\
\text { transparent and equitable to end users than current } \\
\text { methods. (COMPLETED) }\end{array}$ & $\begin{array}{l}\text { DPTM } \\
\text { Range } \\
\text { Master } \\
\text { Planner }\end{array}$ & $\$ 0$ & 0 & & $4 Q$ & & & & & & & & & & & & \\
\hline $\begin{array}{l}\text { Plan for acquisition/development of new ranges, training } \\
\text { areas, and facilities (including classrooms). [Completion } \\
\text { date is indefinite.] }\end{array}$ & DPW & $\begin{array}{l}\$ 60 \mathrm{k} / \mathrm{yr} \\
\text { for } \\
\text { charrettes }\end{array}$ & 0.5 & & $2 Q$ & & & & & & & & & & & & \\
\hline $\begin{array}{l}\text { Partner with Army labs to identify and enable effective } \\
\text { use of mission encroachment planning tools. (INITIATED) }\end{array}$ & DPW & $\begin{array}{l}\text { Approx } \\
\$ 250 k\end{array}$ & 0 & & $\begin{array}{c}1 Q- \\
4 Q\end{array}$ & & & & & & & & & & & & \\
\hline $\begin{array}{l}\text { Identify specific land access projects to implement strate- } \\
\text { gy. }\end{array}$ & DPW & $\begin{array}{l}\text { TBD-- } \\
\text { project } \\
\text { specific }\end{array}$ & 0.5 & & & 10 & & & & & & & & & & & \\
\hline $\begin{array}{l}\text { Explore and pursue access to additional lands as described } \\
\text { under the Joint Land Use Study (JLUS) under development. }\end{array}$ & DPW & $\begin{array}{l}\text { TBD-- } \\
\text { project } \\
\text { specific }\end{array}$ & 0.5 & & & & & & 10 & & & & & & & & \\
\hline $\begin{array}{l}\text { In conjunction with JLUS, research land access strategies } \\
\text { like ACUB, including examples of successful outside } \\
\text { fenceline land access within DoD. }\end{array}$ & $\begin{array}{l}\text { DPW } \\
\text { Master } \\
\text { Planner }\end{array}$ & $\$ 0$ & 0 & $3 Q$ & & & & & & & & & & & & & \\
\hline
\end{tabular}


Goal 6 Description: Identify, provide, operate, sustain, and protect the training areas,

ranges, and facilities needed to support current and future missions conducted at FLW.

Objective 6.3: Operate, modernize, and sustain training land, ranges, and facilities to meet mission requirements. (SR4-2).

Description: Operate includes receiving requests, scheduling, prioritizing, and operational support. Sustainment includes SRM and target maintenance. Implement includes updated technology, equipment, targetry, and support facilities to modernize ranges and enhance capabilities. Ties into DPTM Range Development Plan and Integrated Training Area Management program. Supports SR1-4: Develop more effective and efficient practices to deliver training support to units throughout the ARFORGEN cycles; and SR3-1: Utilize and adapt existing training capabilities and facilities to a transformed Army.

\section{Lead/Proponent: DPTM}

FTE Required for Obj. 6.3: 0.5 FTE in 3Q FY11-2025.

Funding Required for Obj. 6.3: TBD--project specific.

\begin{tabular}{|c|c|c|c|c|c|c|c|c|c|c|c|c|c|c|c|c|c|}
\hline Actions for Objective 6.3 & $\begin{array}{c}\text { Lead } \\
\text { Proponent }\end{array}$ & $\begin{array}{l}\text { Funding } \\
\text { Required }\end{array}$ & $\begin{array}{l}\text { Add'I FTE } \\
\text { Required }\end{array}$ & $\begin{array}{l}\mathrm{FY} \\
11\end{array}$ & $\begin{array}{l}\text { FY } \\
12\end{array}$ & $\begin{array}{l}\mathrm{FY} \\
13\end{array}$ & $\begin{array}{l}F Y \\
14\end{array}$ & $\begin{array}{l}F Y \\
15\end{array}$ & $\begin{array}{l}\mathrm{FY} \\
16\end{array}$ & $\begin{array}{l}\mathrm{FY} \\
17\end{array}$ & $\begin{array}{l}\mathrm{FY} \\
18\end{array}$ & $\begin{array}{l}\mathrm{FY} \\
19\end{array}$ & $\begin{array}{l}\mathrm{FY} \\
20\end{array}$ & $\begin{array}{l}\mathrm{FY} \\
25\end{array}$ & $\begin{array}{l}\mathrm{FY} \\
30\end{array}$ & $\begin{array}{l}\mathrm{FY} \\
35\end{array}$ & $\begin{array}{l}\mathrm{FY} \\
36\end{array}$ \\
\hline $\begin{array}{l}\text { Improve communication among DPTM, G37, S3's, and end } \\
\text { users to develop better understanding of capabilities and } \\
\text { limitations (manage expectations). }\end{array}$ & DPTM & $\$ 0$ & 0 & $3 Q$ & 10 & & & & & & & & & & & & \\
\hline Evaluate scheduling system for opportunities to improve. & DPTM & $\$ 0$ & 0 & & 20 & $2 Q$ & & & & & & & & & & & \\
\hline $\begin{array}{l}\text { Identify and maintain inventory, list of external meetings, } \\
\text { forums, and sources of information on updated range opera- } \\
\text { tions, procedures, technologies, and equipment (i.e., TSSE). } \\
\text { Identify priorities for attendance and participation of FLW } \\
\text { personnel. }\end{array}$ & DPTM & $\$ 0$ & 0 & & 10 & $2 Q$ & & & & & & & & & & & \\
\hline $\begin{array}{l}\text { Ensure that the appropriate POCs attend and participate in } \\
\text { Range Master Planning meetings. [Conducted bi-weekly.] }\end{array}$ & DPTM & $\$ 0$ & 0 & & $2 Q$ & & & & & & & & & & & & \\
\hline $\begin{array}{l}\text { Develop range modernization and/or sustainability projects } \\
\text { based on requirements identified under Obj. } 6.1 \text {. [Start date is } \\
\text { TBD, based on Obj. } 6.1 \text { results. No completion date provided.] }\end{array}$ & DPTM & $\begin{array}{l}\text { TBD-- } \\
\text { project } \\
\text { specific }\end{array}$ & 0 & & & & & & & & & & & & & & \\
\hline
\end{tabular}




\begin{tabular}{|c|c|c|c|c|c|c|c|c|c|c|c|c|c|c|c|c|c|}
\hline Actions for Objective 6.3 & $\begin{array}{c}\text { Lead } \\
\text { Proponent }\end{array}$ & $\begin{array}{l}\text { Funding } \\
\text { Required }\end{array}$ & $\begin{array}{l}\text { Add'I FTE } \\
\text { Required }\end{array}$ & $\begin{array}{l}\mathrm{FY} \\
11\end{array}$ & $\begin{array}{l}\mathrm{FY} \\
12\end{array}$ & $\begin{array}{l}\mathrm{FY} \\
13\end{array}$ & $\begin{array}{l}\text { FY } \\
14\end{array}$ & $\begin{array}{l}\mathrm{FY} \\
15\end{array}$ & $\begin{array}{l}\mathrm{FY} \\
16\end{array}$ & $\begin{array}{l}\text { FY } \\
17\end{array}$ & $\begin{array}{l}\mathrm{FY} \\
18\end{array}$ & $\begin{array}{l}\mathrm{FY} \\
19\end{array}$ & $\begin{array}{l}\mathrm{FY} \\
20\end{array}$ & $\begin{array}{l}\mathrm{FY} \\
25\end{array}$ & $\begin{array}{l}\mathrm{FY} \\
30\end{array}$ & $\begin{array}{l}\mathrm{FY} \\
35\end{array}$ & $\begin{array}{l}\mathrm{FY} \\
36\end{array}$ \\
\hline $\begin{array}{l}\text { (Place holder) Action plan to improve shortfalls in training } \\
\text { support systems such as the Training Support Center and } \\
\text { simulators/simulations. }\end{array}$ & & & & & & & & & & & & & & & & & \\
\hline
\end{tabular}


Goal 6 Description: Identify, provide, operate, sustain, and protect the training areas,

ranges, and facilities needed to support current and future missions conducted at FLW.

Objective 6.4: Protect and preserve training lands for current and future missions.

Description: Use all available and emerging tools/mechanisms/programs and partnerships to buffer and protect training areas from internal and external encroachment. Effective regional sustainable land-use management will also enhance the ability to have watershed and ecosystem-based programs in partnerships between FLW and the surrounding communities to protect drinking water supplies, manage stormwater, manage critical habitats, and provide expanded recreational opportunities.

\section{Lead/Proponent: DPW}

FTE Required for Obj. 6.4: 0.5 FTE in 3Q FY11-13.

Funding Required for Obj. 6.4: \$250k in 3Q FY11

\begin{tabular}{|c|c|c|c|c|c|c|c|c|c|c|c|c|c|c|c|c|c|}
\hline Actions for Objective 6.4 & $\begin{array}{c}\text { Lead / } \\
\text { Proponent }\end{array}$ & $\begin{array}{l}\text { Funding } \\
\text { Required }\end{array}$ & $\begin{array}{l}\text { Add'I } \\
\text { FTE } \\
\text { Required }\end{array}$ & $\begin{array}{l}\text { FY } \\
11\end{array}$ & $\begin{array}{l}\mathrm{FY} \\
12\end{array}$ & $\begin{array}{l}\text { FY } \\
13\end{array}$ & $\begin{array}{l}\text { FY } \\
14\end{array}$ & $\begin{array}{l}\text { FY } \\
15\end{array}$ & $\begin{array}{l}\text { FY } \\
16\end{array}$ & $\begin{array}{l}\mathrm{FY} \\
17\end{array}$ & $\begin{array}{l}\text { FY } \\
18\end{array}$ & $\begin{array}{l}\mathrm{FY} \\
19\end{array}$ & $\begin{array}{l}\mathrm{FY} \\
20\end{array}$ & $\begin{array}{l}\mathrm{FY} \\
25\end{array}$ & $\begin{array}{l}\text { FY } \\
30\end{array}$ & $\begin{array}{l}\text { FY } \\
35\end{array}$ & $\begin{array}{l}\mathrm{FY} \\
36\end{array}$ \\
\hline $\begin{array}{l}\text { Develop an installation-wide sustainable Real Property Master } \\
\text { Plan (builds on the existing RPMP and RDP) and includes com- } \\
\text { patible development zones for all areas controlled by FLW. }\end{array}$ & DPW & \multicolumn{2}{|c|}{$\begin{array}{l}\text { Staff and funds to } \\
\text { revise the RPMP are } \\
\text { identified under Goal } \\
1, \text { Objective } 1.1\end{array}$} & & $4 Q$ & & & & & & & & & & & & \\
\hline Request JLUS through command. & DPW & $\$ 0$ & 0 & & & & & & & & & & & & & & \\
\hline $\begin{array}{l}\text { Develop and implement a mutually beneficial ACUB plan } \\
\text { and/or other mitigation strategies to correct encroachment } \\
\text { identified by JLUS or other study (hold until JLUS completed). }\end{array}$ & DPW & $\$ 250 k$ & 0.5 & & 30 & & & & & & & & & & & & \\
\hline $\begin{array}{l}\text { Screen and correct facility category codes for ranges, training, } \\
\text { and maneuver lands. (INITIATED) }\end{array}$ & DPTM & $\$ 0$ & 0 & & 30 & & & & & & & & & & & & \\
\hline $\begin{array}{l}\text { Include ranges and training areas into installation-wide } \\
\text { stormwater management plan and stormwater P2 plan (man- } \\
\text { dated). (INITIATED) }\end{array}$ & DPTM & $\$ 0$ & 0 & & & & & & & & & & & & & & \\
\hline $\begin{array}{l}\text { Develop programmatic approach with G37, DPTM, and DPW to } \\
\text { reduce the environmental impacts of training activities and } \\
\text { improve the natural infrastructure. (INITIATED) }\end{array}$ & DPTM & $\$ 0$ & 0 & & 30 & & & & & & & & & & & & \\
\hline $\begin{array}{l}\text { Coordinate with community engagement team and/or PAO to } \\
\text { include training events notice in Obj. } 3.5 \text { (look into models for } \\
\text { range noise impacts -- RONIP?). }\end{array}$ & DPTM & $\$ 0$ & 0 & & 30 & & & & & & & & & & & & \\
\hline
\end{tabular}




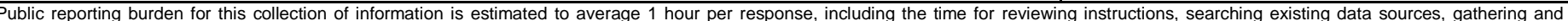

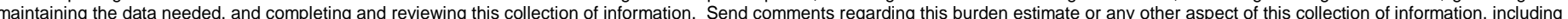

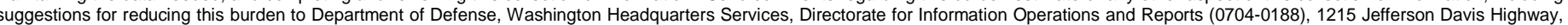

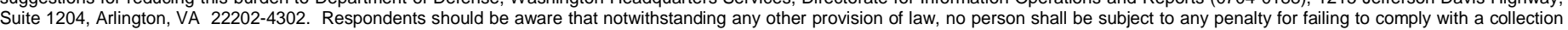
of information if it does not display a currently valid OMB control number. PLEASE DO NOT RETURN YOUR FORM TO THE ABOVE ADDRESS.

\begin{tabular}{l|l} 
1. REPORT DATE (DD-MM-YYYY) & 2. REPORT TYPE
\end{tabular} May 2012

4. TITLE AND SUBTITLE

Fort Leonard Wood Integrated Strategic Sustainability Plan

3. DATES COVERED (From - To)

5a. CONTRACT NUMBER

5b. GRANT NUMBER

5c. PROGRAM ELEMENT NUMBER

6. AUTHOR(S)

Kevin Palmer, Sarah Nemeth, Annette Stumpf, and Susan Bevelheimer

5d. PROJECT NUMBER

5e. TASK NUMBER

FLWCTO Task \#PAIO-11-108-26

5f. WORK UNIT NUMBER

7. PERFORMING ORGANIZATION NAME(S) AND ADDRESS(ES)

U.S. Army Engineer Research and Development Center

Construction Engineering Research Laboratory

P.O. Box 9005

Champaign, IL 61826-9005

8. PERFORMING ORGANIZATION REPORT NUMBER

ERDC/CERL SR-12-7

9. SPONSORING I MONITORING AGENCY NAME(S) AND ADDRESS(ES)

US Army Garrison Fort Leonard Wood

Plan, Analysis and Integration Office

Fort Leonard Wood, MO 65473
10. SPONSOR/MONITOR'S ACRONYM(S)

FLW

11. SPONSOR/MONITOR'S REPORT NUMBER(S)

\section{DISTRIBUTION I AVAILABILITY STATEMENT}

Approved for public release; distribution is unlimited.

\section{SUPPLEMENTARY NOTES}

\section{ABSTRACT}

The US Army recognizes its obligation to ensure that Soldiers have the land, water, and air resources needed to train; a healthy environment; adaptable facilities; and the support of local communities, government officials, and the American people. An Integrated Strategic Sustainability Plan (ISSP) was developed to ensure that US Army Garrison Fort Leonard Wood (FLW) can preserve these resources, to continue meeting mission requirements in the future. This work represents the initial ISSP developed for FLW, a complex installation that meets multiple training needs for the Army and other military commands. To develop a viable long-range ISSP requires significant involvement by Garrison and Maneuver Support Center of Excellence personnel. Their important work was facilitated through collaboration with contractors, US Army Corps of Engineers, and Installation Management Command personnel. The result is a working plan containing six strategic sustainability goals that align with FLW's six core business areas. The work also includes related factors, such as action plans to guide and indicators to track FLW's progress in meeting its goals. This ISSP will evolve as various objectives, action plans, and measures may be refined. Team members will utilize online resources to facilitate development of the plan over its expected 25-year lifespan. The information and data presented in this document were current as of the end of FY11 (September 2011).

\section{SUBJECT TERMS}

strategic planning, sustainability, US Army, Fort Leonard Wood, Integrated Strategic Sustainability Plan (ISSP), Maneuver Support Center of Excellence (MSCoE)

\section{SECURITY CLASSIFICATION OF:}

\begin{tabular}{|l|c|r|}
\hline a. REPORT & b. ABSTRACT & c. THIS PAGE \\
Unclassified & Unclassified & Unclassified \\
\hline
\end{tabular}

\begin{tabular}{l|} 
17. LIMITATION \\
OF ABSTRACT
\end{tabular}

\section{NUMBER 19 a. NAME OF RESPONSIBLE OF PAGES \\ PERSON}

126 19b. TELEPHONE NUMBER (include area code) 